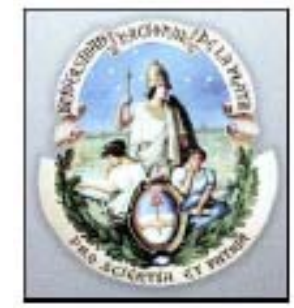

Universidad Nacional de La Plata

Facultad de Ciencias Exactas

Departamento de Ciencias Biológicas

Instituto de Biotecnología y Biología Molecular

(IBBM, UNLP-CONICET, La Plata)

“Caracterización biológica y molecular de genes involucrados en la virulencia de baculovirus de importancia agronómica"

Ricardo Salvador

Tesis Doctoral

2010 
El presente trabajo de Tesis, para optar al grado de Doctor en Ciencias de la Facultad de Ciencias Exactas, ha sido realizado en el Instituto de Biotecnología y Biología Molecular (IBBM, UNLP-CONICET), Departamento de Ciencias Biológicas, Facultad de Ciencias Exactas, Universidad Nacional de La Plata y en el Instituto de Microbiología y Zoología Agrícola (IMYZA), perteneciente al Instituto Nacional de Tecnología Agropecuaria (INTA); bajo la dirección del Profesor Dr. Victor Romanowski y de la Ing. Agr. Alicia Sciocco de Cap 
MI RECONOCIMIENTO A LA AGENCIA NACIONAL DE PROMOCIÓN CIENTÍFICA Y TECNOLÓGICA (ANPCYT), A LA UNIVERSIDAD NACIONAL DE LA PLATA y AL INSTITUTO NACIONAL DE TECNOLOGIA AGROPECUARIA POR HABER HECHO POSIBLE LA REALIZACIÓN DEL PRESENTE TRABAJO. 
Agradecimientos

A mis directores el Dr. Víctor Romanowski y Alicia Sciocco de Cap. Primero las damas; a Alicia Sciocco de Cap por transmitirme sin mezquindades y mucha paciencia su saber. Por perdonar mis desaciertos y elogiar los avances. Gracias por la confianza demostrada en estos años y haber guiado con sus ideas y todo lo que estuvo a su alcance este trabajo. También por contar conmigo en los nuevos proyectos y haberme abierto las puertas del INTA para formar parte de su grupo de trabajo .Gracias por todo!!!

Al Dr. Victor Romanowski por poner su experiencia e ideas en este trabajo. Gracias por brindarme la confianza y paciencia que fue necesaria en todo este tiempo. Por guiar, pero a la vez darme libertad de acción en el desarrollo de esta tesis. Por permitirme ser parte de su grupo de investigación y poner a mi disposición todo lo necesario para lograr los objetivos. Muchas Gracias!!!

Al Dr. Ricardo Gomez y la Ing. Graciela Quintana por sus aportes de las más diversas formas a la realización de este trabajo. Gracias!!!

A la Dra. Fernanda Zanca y el Dr. Marcelo Berreta, por compartir su experiencia y estar disponibles cada vez que fue necesario.

A mis compañeros de laboratorio del IBBM, los primeros y que ya emigraron, Diego, la Sole, Javi, el Colo, la Mini, Eduardo, Alejandra (ch), Alejandra (carni). Por guiarme en mis primeros tiempos dentro del laboratorio, por la ayuda y por haberme hecho disfrutar los días de trabajo compartidos. Gracias!!!! A los que están, a Leti, Gaby y Caro, por su amistad, compañerismo y fundamental ayuda en el día a día! A los más nuevos, Mandi, Maia, Santi, Leo, Matias, Magdalena, Jesi y Lucre por dar una mano siempre que se necesitó. Gracias a todos porque tuve la suerte de formar parte de un grupo de buenas personas, que hicieron y hacen del lugar de trabajo un espacio para disfrutar. 
A mis compañeros del IMYZA, a Marcelo B., Marcelo F., Joel y Lorena por hacerme un espacio en el laboratorio, por cooperar de forma desinteresada en mi trabajo, dejarme participar en el de ellos y hacer siempre muy agradable $\mathrm{mi}$ estadía en Castelar. Gracias por todo!!! A María y Debora por haber mantenido la cría de los insectos con los cuales se realizaron los experimentos en esta tesis.

A mis compañeros del IBBM: a Nacho (Gallo para los Belgranenses) quien no sólo es un compañero de trabajo sino también un intergrante del grupo de buenos amigos que me dejó la Facultad, gracias por tu ayuda en el labo y tantos años de buena amistad!. A Pity, Pistorio, Florencia, Federico, Julieta, JPG, Florcita, Julia, Emilia, Daniela, Finger, Augusto, Angie, Gonzalo, Mauricio, Carina y Verónica. A todos gracias porque siempre de alguna manera dieron una mano!

A Caty, por su valioso trabajo en el día a día y por contar con su ayuda cada vez que fue necesario. A Rubencito por colaborar en lo que estuviera a su alcance y $\mathrm{mi}$ reconocimiento a Carlitos por las divertidas charlas compartidas y su ayuda en el mantenimiento del laboratorio.

A los Dres. Laura García, Antonio Lagares, Anibal Lodeiro, Daniela Hozbor y Mario Aguilar, por permitirme hacer uso de sus equipamientos, necesarios para muchas de las experiencias realizadas en este trabajo.

A Silvia Moya, por su siempre amable y desinteresado interés en resolver los problemas de carácter administrativo que fueron surgiendo a lo largo de estos años. Gracias!

A la gente de Biotecnología del INTA, Castelar, Andrea P, Gabriela y Oscar, por su siempre gentil colaboración de una manera u otra en este trabajo. Gracias! A Esteban por su confianza depositada para los nuevos proyectos y darme el tiempo necesario para poder concluir esta tesis! 
A Hernán, Luciano, Marcos, Soledad, Fito, Nadia, Marcelo Pecoraro., Cecilia Galosi, Gabriela Echeverria y Teresa Gonzales del Laboratorio de Virología de la Facultad de Ciencias Veterinarias de la UNLP por su cooperación desinteresada cada vez que fue necesario.

A mis compañeros de la Cátedra de Biología, por disculpar mis faltazos en esta ultima etapa de escritura de la tesis. Gracias!

A mis amigos y afectos, Hugo, Horacio, Pancho, Pablo, Debo, La Flaca, la Coca, Mariana, el Colo, Sole, el Sapo, Diego, Chifi, Antonio, Minino, el Flaco y el Taco por no cuestionar mis ausencias en estos últimos tiempos!

Finalmente a toda mi familia, mi bien más preciado, por estar siempre a mi lado. 


\section{Abreviaturas utilizadas en este trabajo}

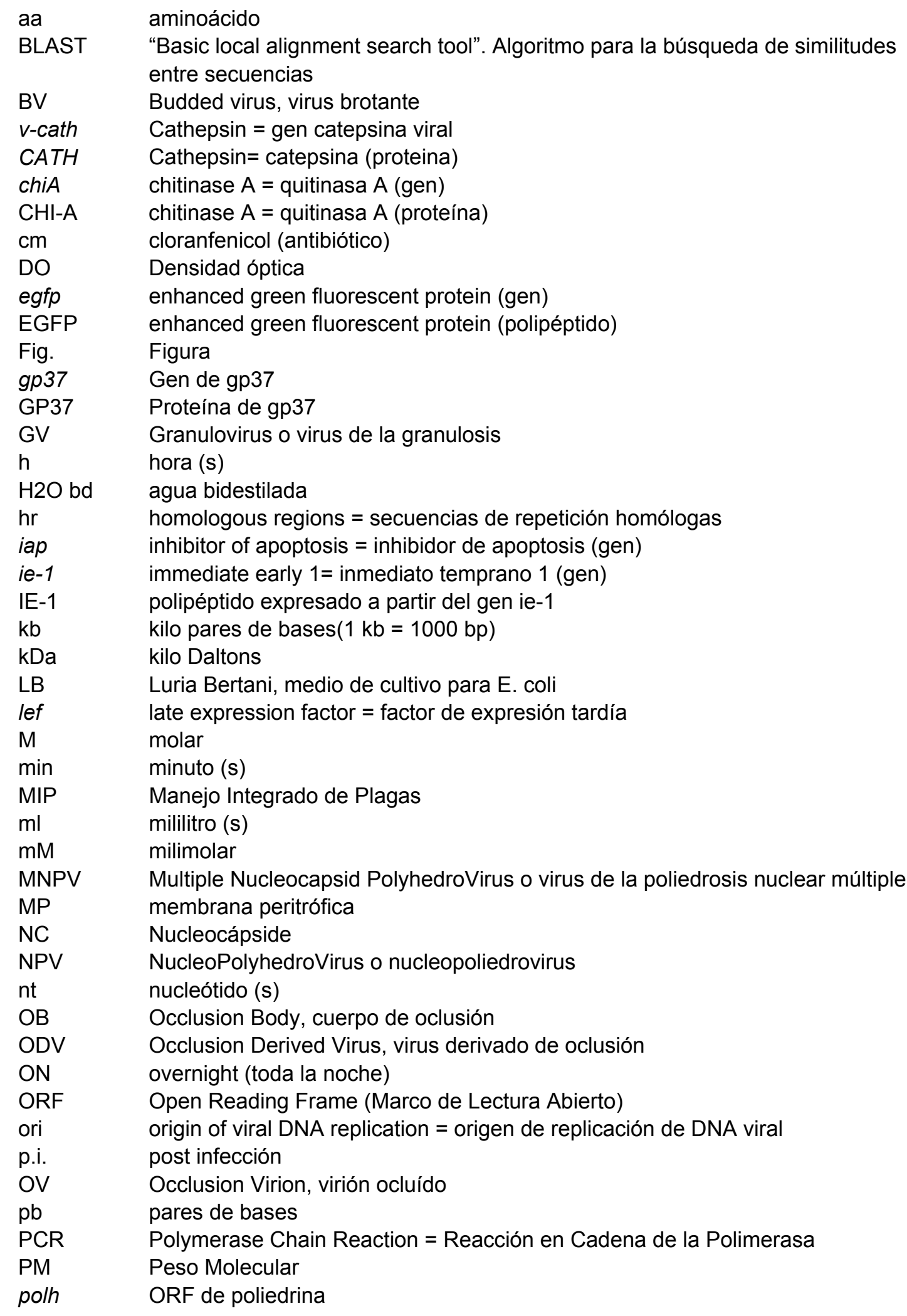


rpm revoluciones por minuto

SNPV Single Nucleocapsid PolyhedroVirus o virus de la poliedrosis nuclear simple

TA Temperatura Ambiente

UV ultravioleta

V Volts (voltios)

vef viral enhancing factor $=$ factor aumentador viral (gen)

VEF viral enhancing factor $=$ factor aumentador viral (proteína)

$\mu \mathrm{l} \quad$ microlitro

$\mu \mathrm{m} \quad$ micrómetro 


\section{INDICE GENERAL}

Capítulo 1. Introducción

Capítulo 2. Evaluación de los efectos de EpapGV como incrementador de virulencia de nucleopoliedrovirus

Capítulo 3. Estudio y caracterización de un homólogo a gp37 encontrado en el genoma de EpapGV

Capítulo 4. Caracterización de la quitinasa de EpapGV

Capítulo 5. Evaluación de genes de EpapGV en baculovirus recombinantes 


\section{Introducción}




\section{Indice temático}

$\begin{array}{ll}\text { Baculovirus } & 3\end{array}$

Estructura y composición de los baculovirus 5

Ciclo de infección 11

Uso de baculovirus en el control biológico de plagas 16

$\begin{array}{ll}\text { Epinotia (=Crocidosema) aporema (Wals) } & 18\end{array}$

$\begin{array}{ll}\text { Virus de la granulosis de Epinotia aporema } & 19\end{array}$

Anticarsia gemmatalis (Hübner) 21

Nucleopoliedrovirus de Anticarsia gemmatalis (AgMNPV) 22

$\begin{array}{ll}\text { Spodoptera frugiperda (Smith) } & 23\end{array}$

Contexto de trabajo $\quad 25$

$\begin{array}{ll}\text { Hipótesis } & 25\end{array}$

$\begin{array}{ll}\text { Objetivo general de la Tesis } & 26\end{array}$

Objetivos Particulares $\quad 27$

$\begin{array}{lr}\text { Referencias } & 28\end{array}$ 


\section{Baculovirus}

La historia del descubrimiento de los baculovirus está íntimamente relacionada con el desarrollo de la industria de la seda que se originó en China hace 5.000 años. La cría del "gusano de seda" (Bombyx mori, Lepidoptera: Bombycidae) se extendió por todo Asia, llegando a Japón a través de Corea aproximadamente en el año 300 D.C. Posteriormente comenzó a practicarse en Europa alrededor del año 550 D.C. y llegó a México por los años 1.500 (Benz, 1986; Rohrmann, 2008). Las mermas en la producción asociadas a patologías observadas en los gusanos de seda, motivó el estudio de sus agentes causales. Hacia mediados del siglo XIX, con el advenimiento del uso y mejora en la calidad del microscopio óptico, se determinó que una de las enfermedades que afectaba a las larvas se caracterizaba por la presencia de cuerpos de oclusión poliédricos, en las células infectadas. Ello condujo a la posterior denominación de la enfermedad como "poliedrosis". Aunque la presencia de partículas infecciosas dentro de los cuerpos de oclusión se había sugerido anteriormente, recién hacia finales de la década de 1940 se demostró de manera convincente la presencia de viriones en forma de bastón, mediante microscopía electrónica (Bergold, 1952; Rohrmann, 2008). Posteriormente se comenzó a designar como virus de la poliedrosis nuclear (Nuclear Polyhedrosis Virus, NPV) a aquellos virus cuyos cuerpos de oclusión se localizaban en el núcleo de la célula, distinguiéndolos de las poliedrosis citoplasmáticas (CPV, Fam. Reoviridae).

Por otra parte, en la década de 1920 se describió otra enfermedad que afectaba a insectos del Orden Lepidóptera y que se caracterizaba por la presencia de cuerpos de oclusión pequeños y de forma granular, la cual fue denominada "virus de la granulosis" (Granulosis Virus, GV) (Paillot, 1926; Rohrmann, 2008).

El término baculovirus fue sugerido por el Dr. Mauro Martignoni y deriva del latín baculum (bastón) aludiendo a la forma de los viriones. En 1973, se creó la Familia Baculoviridae (Vago, 1974).

Esta familia agrupa a virus que se caracterizan por presentar un genoma de DNA doble cadena, circular, súper-enrollado, que varía entre 80 y $180 \mathrm{kpb}$ y codifica entre 90 y 180 genes. En la mayoría de los baculovirus existen dos tipos de viriones 
con idéntico genotipo y diferente fenotipo: viriones ocluidos (occluded virions, OVs u occluded derived virions, ODVs) y viriones brotantes (budded virions, BVs), los cuales cumplen roles diferentes durante el ciclo biológico del virus. En todos los casos, presentan cuerpos de oclusión (occlusion bodies, OBs) donde se ocluyen los OVs.

El tamaño y la forma de los OBs se ha aprovechado para clasificar a la familia Baculoviridae en dos géneros: Nucleopolyhedrovirus (NPV) y Granulovirus (GV) (Theilmann et al., 2005). Recientemente, sobre la base del conocimiento de secuencias genómicas baculovirales y sus relaciones filogenéticas, se ha sugerido la división de esta familia en cuatro géneros (Fig. 1.1) (Jehle et al., 2006):

El género Alphabaculovirus incluye a todos los Nucleopolyhedrovirus específicos de lepidópteros. Los miembros de este género producen tanto viriones brotantes como viriones ocluidos, los cuales pueden presentar una o varias nucleocápsides por virión (SNPV o MNPV, respectivamente). Morfológicamente el cuerpo de oclusión mide aproximadamente 0,4 - $3 \mu \mathrm{m}$ de diámetro. El tamaño del genoma oscila entre 100 y $180 \mathrm{kbp}$. La especie tipo propuesta es Autographa californica Nucleopolyhedrovirus (AcMNPV). Por otra parte, entre los NPVs de lepidópteros se distinguen los grupos I y II. Ambos difieren en su contenido génico y en la proteína de fusión funcional en los viriones brotantes: GP64 y F, respectivamente.

El género Betabaculovirus incluye a representantes específicos que infectan sólo lepidópteros, nombrados anteriormente como Granulovirus. En su ciclo replicativo producen tanto viriones brotantes como ocluidos. El tamaño del $\mathrm{OB}$ es de aproximadamente $300-500 \mathrm{~nm} \times 130-250 \mathrm{~nm}$. El genoma puede poseer entre $100 \mathrm{y}$ $180 \mathrm{kbp}$. Como especie tipo se propuso al granulovirus Cydia pomonella (CpGV).

El género Gammabaculovirus incluye a los Nucleopolyhedrovirus aislados de himenópteros. Presentan cuerpos de oclusión poliédricos de unos 0,4 -1,1 $\mu \mathrm{m}$ diámetro, con una sola nucleocápside por virión (SNPV). El tamaño de los genomas de NeleNPV (Neodiprion lecontei Nucleopolyhedrovirus) y de NeseNPV (Neodiprion sertifer Nucleopolyhedrovirus) es de 82 y $86 \mathrm{kbp}$, respectivamente. El fenotipo brotante puede estar ausente. La especie tipo propuesta es Neodiprion lecontei Nucleopolyhedrovirus (NeleNPV). 
Por último, el género Deltabaculovirus incluye a Culex nigripalpus Nucleopolyhedrovirus (CuniNPV) y otros baculovirus específicos de dípteros. Tanto los BV como los ODV están descriptos en el ciclo viral. CuniNPV presenta OBs de forma globular de unos $400 \mathrm{~nm}$ de diámetro. La proteína constituyente del cuerpo de oclusión no es homóloga ni a la poliedrina ni a la granulina. La especie tipo propuesta en este caso es Culex nigripalpus nucleopolyhedrovirus (CuniNPV).

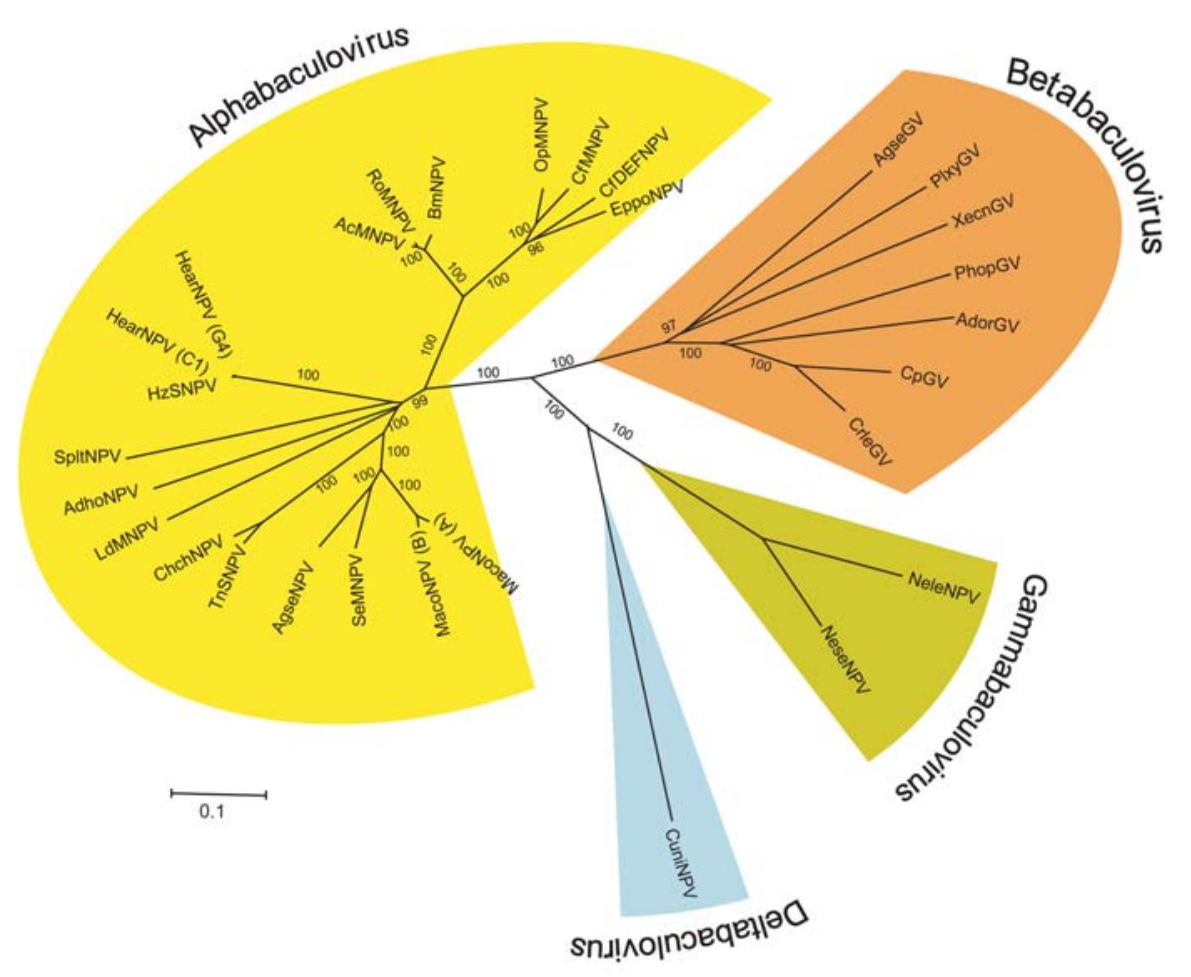

Fig.1.1. Árbol filogenético con géneros y especies incluídas en la Familia Baculoviridae (Jehle et al., 2006).

\section{Estructura y composición de los baculovirus}

El genoma viral se encuentra empaquetado en nucleocápsides contenidas en viriones con forma de bastón, que miden aproximadamente $200 \mathrm{~nm}$ de largo por 30 $\mathrm{nm}$ de diámetro. Durante el ciclo de replicación viral, pueden presentar dos fenotipos virales con roles diferentes. Un fenotipo viral ocluido (OV, ODV) en una matriz proteica (constituída principalmente por granulina o poliedrina), el cual se 
produce en grandes cantidades en las etapas finales de la infección y está especializado en la transmisión horizontal del virus de insecto a insecto susceptible (Theilmann et al., 2005). Los cuerpos de oclusión que los contienen son liberados en el medio ambiente cuando el hospedador infectado muere y son capaces de persistir en la naturaleza, principalmente en el suelo y hojarasca, durante largos períodos de tiempo. Esta permanencia en el ambiente constituye una fuente de inóculo para generaciones subsiguientes de la plaga y un medio de control de la densidad poblacional del insecto (Kalmakoff, 1982).

Como se ha mencionado, los OVs se encuentran contenidos dentro de cuerpos de oclusión de formas y tamaños diversos, según la especie y género baculoviral.

\section{Estructura de los cuerpos de oclusión}

Los cuerpos de oclusión (OBs) están constituidos mayoritariamente por poliedrina o granulina (según el género baculoviral) (Fig. 1.2). Estas son los componentes estructurales más importantes del OB y ambas proteínas contienen aproximadamente 250 aa (30 kDa), siendo las más conservadas entre los baculovirus. Se encuentran homólogos en todos los genomas baculovirales (Funk, 1997). Como excepción se puede mencionar CuniNPV, en el que la secuencia aminoacídica de la proteína constituyente de los OBs parece no estar relacionada con la secuencia de la poliedrina de otros baculovirus (Afonso et al., 2001; Perera et al., 2006).

Otro componente del OB es su envoltura, cuya función parece estar asociada a sellar la superficie de los poliedros y aumentar su estabilidad (Rohrmann, 2008). En su composición se encuentran hidratos de carbono (Minion, 1979) y una proteína fosforilada que fue posteriormente identificada como PE (Ac131) (Whitt \& Manning, 1988) y que presenta homólogos en los genomas de todos los baculovirus que infectan lepidópteros, secuenciados hasta el presente (van Oers \& Vlak, 2007).

Entre las factores asociados a los OBs se puede citar además a Ac68, que parecería estar involucrada con la morfogénesis del poliedro (Xu et al., 2008b). La proteína P10 (Ac137) es requerida para la correcta formación de los poliedros y cuando es fosforilada se la encuentra asociada a microtúbulos (Cheley et al., 1992). 
La deleción de $p 10$ en el genoma viral ocasiona la malformación de poliedros y la formación de una envoltura incompleta (Gross et al., 1994).

A

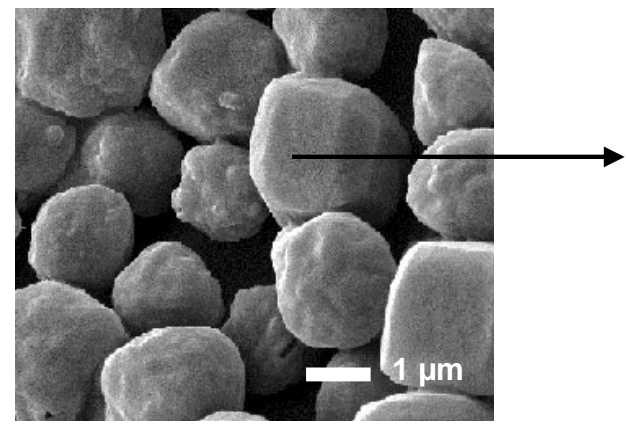

$\mathrm{B}$

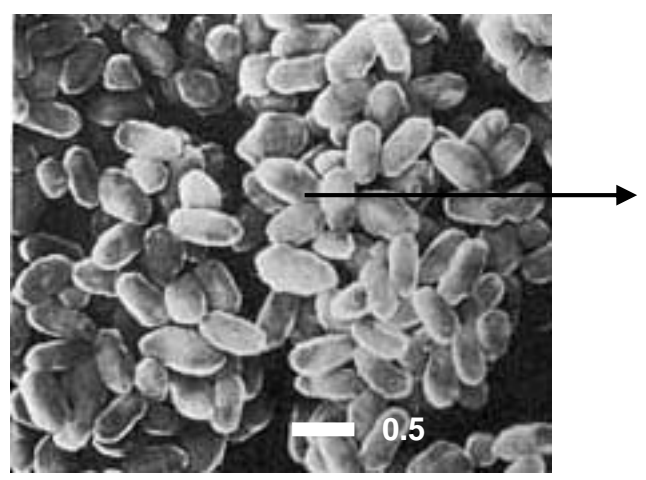

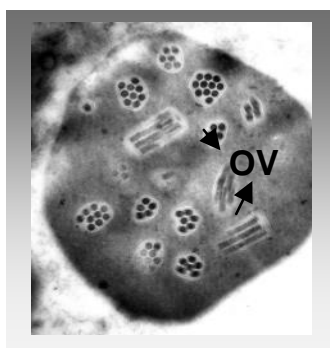

C

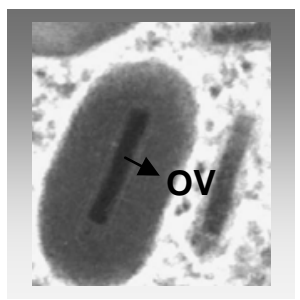

D

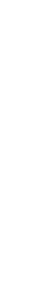

Fig. 1.2. A y B: Micrografías electrónicas de barrido de un NPV y un GV. C y D: Micrografías electrónicas de cortes ultrafinos de cuerpos de oclusión (OV: virones ocluidos)

Las proteínas VEFs (Viral enhancing factors o enhancins) pueden aparecer asociadas a los OBs de ciertos baculovirus; son metaloproteasas que en el caso de TnGV llegan a representar el 5\% de la masa del OB (Hashimoto et al., 1991). Estas proteasas facilitan la infección viral por disrupción de la membrana peritrófica (MP) del hospedador (Derksen \& Granados, 1988; Lepore et al., 1996; Peng et al., 1999; Tanada et al., 1973; Wang \& Granados, 1997)

\section{Estructura de viriones ocluidos}

Los viriones ocluidos dentro de la matriz proteica del $\mathrm{OB}$ poseen una envoltura constituída por diversas proteínas designadas como ODV-E (Fig. 1.3). Como 
ejemplo la ODV-E66 en AcMNPV (Ac46) codifica una enzima que es capaz de digerir el ácido hialurónico, que es un polisacárido importante de la matriz extracelular (Vigdorovich et al., 2007). Homólogos a esta proteína se encuentran casi todos los baculovirus, excepto los aislados de himenópteros y dípteros (van Oers \& Vlak, 2007).

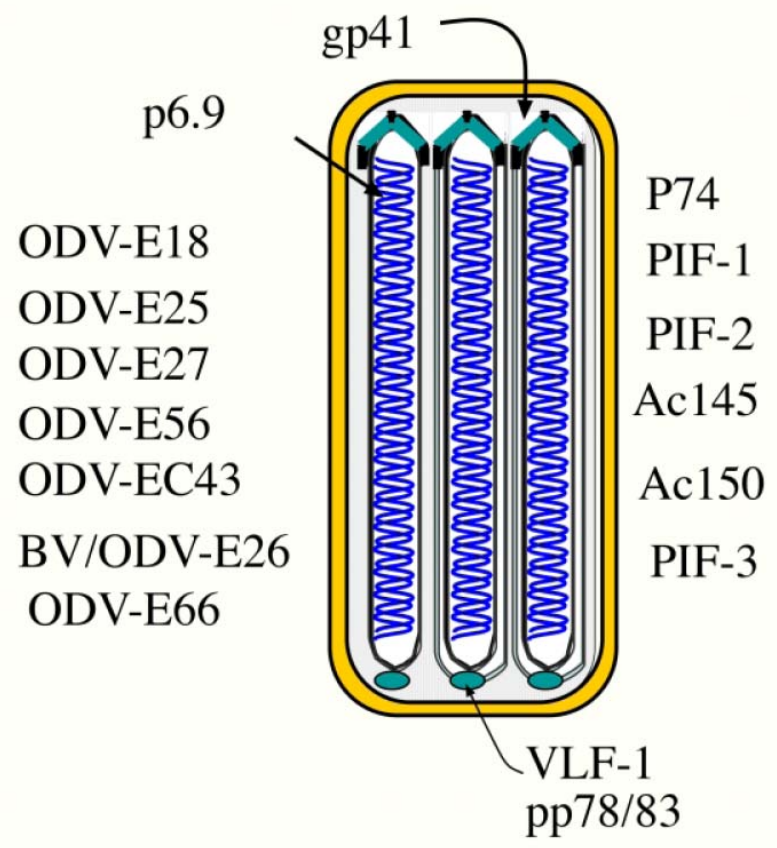

Fig.1.3. Componentes proteicos de un virión derivado del cuerpo de oclusión. ODV-E: proteínas de la envoltura del ODV. PIF/ P74/ Ac145/ Ac150: Factores de infección per os. (Fuente: Rohrmann, 2008)

Otro grupo de proteínas encontradas en la envoltura que rodea a los ODV se asocia a la infección de los insectos por vía oral, por lo cual fueron designadas con el nombre de per os infectivity factors (PIF). Se identificaron cuatro genes pif en AcMNPV denominados p74-pif (Ac138), Ac 22 (pif-2), Ac115 (pif-3), y Ac119 (pif-1). Homólogos de estos cuatro genes están presentes en los genomas de todos los baculovirus. Las proteínas PIF1, PIF2, y p74 actúan mediando de forma específica la unión de los ODV a las células del intestino medio, sugiriéndose que están directamente involucradas en la interacción virus-célula en las etapas iniciales de la infección (Ohkawa et al., 2005). Otros dos genes hallados en AcMNPV (Ac 145 y Ac150), posiblemente presentan una función similar a los genes pif, ya que al ser 
ambos delecionados en AcMNPV, el virus modificado resultó ser menos infectivo que el salvaje (Lapointe, 2004).

\section{Estructura de la nucleocápside (NC)}

Cada OV puede contener en su interior una (GVs y SNPV) o varias nucleocápsides (MNPV), cuya estructura es común con la de los viriones brotantes (BV). La nucleocápside (NC) está conformada por DNA superenrollado íntimamente asociado a la proteína P6.9. Esta proteína con capacidad de unión a DNA participa en alto grado de la compactación que presenta el material genético viral.

Por otra parte, la proteína VLF-1 (Ac77) (very late factor), está ubicada en la región terminal de la NC y tiene funciones estructurales tanto en los ODV como en los BV (Yang \& Miller, 1998).

La cápside del virión está compuesta principalmente por la proteína VP39 (Ac89), que posee homólogos en todos los genomas baculovirales. Entre otras proteínas de importancia que están presentes en los viriones se pueden citar a GP41 (Ac80), que se encuentra localizada entre la envoltura del virión y la cápside, constituyendo una estructura denominada tegumento (Whitford \& Faulkner, 1992) que es requerida para el egreso de la nucleocápside del núcleo (Olszewski \& Miller, 1997).

Ac142 (p49), es otro componente de la nucleocápside del BV y del ODV. Está presente en todos los baculovirus secuenciados (Rohrmann, 2008). Mediante estudios bajo microscopio electrónico se reveló que es requerido en la nucleocápside para formar el ODV y su posterior oclusión en el OB (McCarthy \& Theilmann, 2008). Por último, la proteína Ac144 asociada al virión, podría estar involucrada en el procesamiento del DNA, su empaquetado y en la morfogénesis de la NC (Vanarsdall et al., 2007).

\section{Estructura de los viriones brotantes (BVs)}

Los BVs representan el segundo fenotipo viral hallado en el ciclo infectivo de los baculovirus. Estos poseen una envoltura diferente a la encontrada en los ODVs, lo cual les permite realizar una infección a nivel sistémico (de célula en célula dentro 
del hemocele del insecto). Los OVs infectan células del epitelio intestinal unas 10.000 veces más eficientemente que los BVs. Mientas que estos últimos son, en cambio, 1.000 más infectivos en cultivos celulares (Rohrmann, 2008).

Estructuralmente los BVs poseen en su envoltura una proteína con actividad fusogénica bien caracterizada denominada GP64 (Ac128). Debido a su importancia en la infectividad del BV se pensó que estaría presente en todos los baculovirus (Monsma et al., 1996; Oomens et al., 1995). El análisis de diversos genomas demostró la ausencia de homólogos a este ORF, en los cuales la función de fusión era cumplida por una proteína denominada $\mathrm{F}$ (prot. F). Algunos baculovirus poseen ambos ORFs pero en esos casos, la proteína $F$ es inactiva. Según estudios realizados en tal sentido, se postula que gp64 podría haberse adquirido en diferentes linajes baculovirales en los cuales la actividad de la proteína $F$ fue desplazada (Rohrmann, 2008). Como se ha mencionado, la presencia/ausencia de este ORF es utilizada para agrupar a los NPV dentro de los grupos I y II (Fig.1.4).

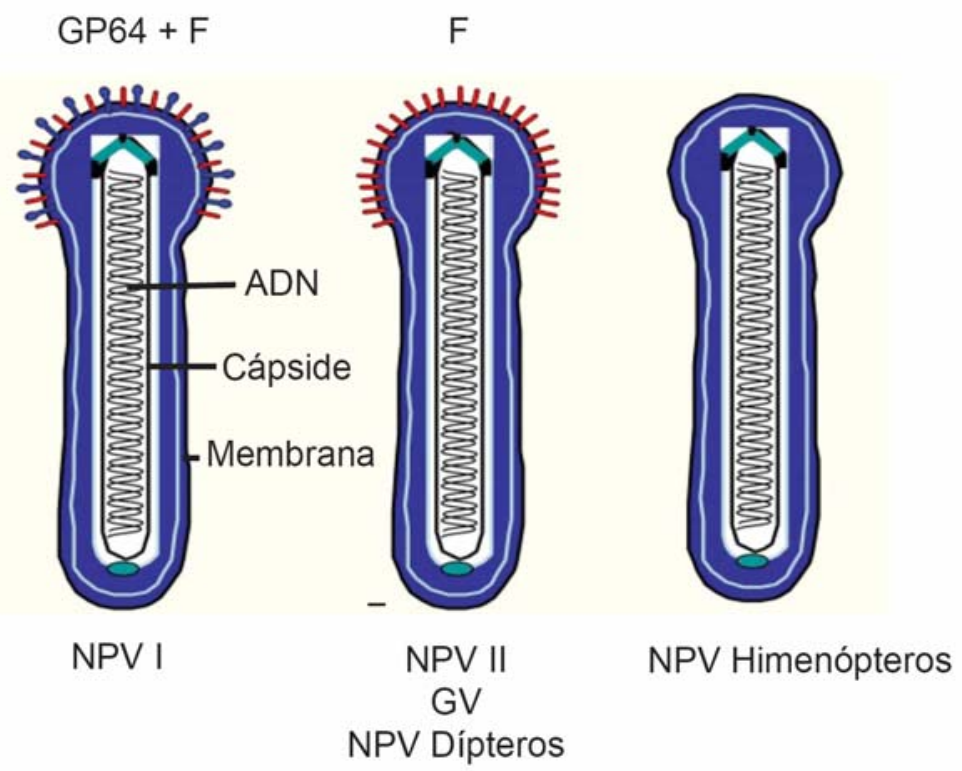

Fig. 1.4. Estructura de BV y distribución de GP64/F en los diferentes grupos

Si bien la proteína $F$ (Ac23) no posee actividad fusogénica en AcMNPV, cuando es delecionada se observa un aumento del tiempo letal (Pearson et al., 2001a). Los 
representantes del grupo II de NPVs, GVs y baculovirus aislados de dípteros utilizan la proteína $\mathrm{F}$ como proteína de fusión y carecen de homólogos a gp64. La inserción del ORF correspondiente a la proteína F de Agrotis segetum Granulovirus en el genoma de AcMNPV en el cual gp64 fue delecionado demostró ser capaz de rescatar la infectividad (Yin et al., 2008).

\section{Ciclo de infección}

Para entender el ciclo de infección de los baculovirus, es necesario referirse someramente al tracto gastrointestinal del insecto, ya que es en este sitio donde transcurren las primeras etapas del mismo. El intestino de este grupo de artrópodos se compone de tres secciones: intestino anterior, medio y posterior. En lepidópteros, el intestino anterior cumple la función de facilitar la absorción, el almacenamiento y la transformación física de los alimentos. Está recubierto por una cutícula que contiene quitina y que forma parte del exoesqueleto del insecto. Una válvula separa el intestino anterior del intestino medio. Este último está involucrado en la secreción de enzimas y en la absorción de los alimentos digeridos. En la entrada y salida del intestino medio, el pH es cercano a 7,0, pero en la región central puede variar entre 10 y12, dependiendo de las especies de lepidópteros (Dow, 1992). Otra válvula separa el intestino medio del intestino posterior. Éste se encuentra recubierto por una cutícula similar a la del intestino anterior y está involucrado en la captación de material digerido, aunque en menor medida que el intestino medio.

El intestino medio si bien carece de una cutícula, está recubierto internamente por una estructura acelular denominada la membrana peritrófica (MP) (Fig. 1.5) (Peters, 1992). Esta membrana no está presente en todos los grupos de insectos, faltando en grupos como ftirápteros (piojos) y tisanópteros (pescaditos de plata), entre otros (Peters, 1992). La presencia de la MP durante el ciclo vital de los insectos que la poseen, es variable y en algunos aparece solo en los estadios larvales mientras que en otros puede estar presente en todos los estados del ciclo (Waterhouse, 1953).

Tradicionalmente, las MPs de los insectos se clasifican en tipo I y tipo II de acuerdo con su formación (Wigglesworth, 1930). Las MPs de tipo I son producidas a lo largo de todo el intestino medio, lo que se cree que es la situación ancestral y se 
encuentra en la mayoría de las especies en la actualidad. Las MPs Tipo II son producidas por células de una zona restringida del intestino medio anterior de dípteros, dermápteros, como así también de algunas familias de lepidópteros (Peters, 1992).

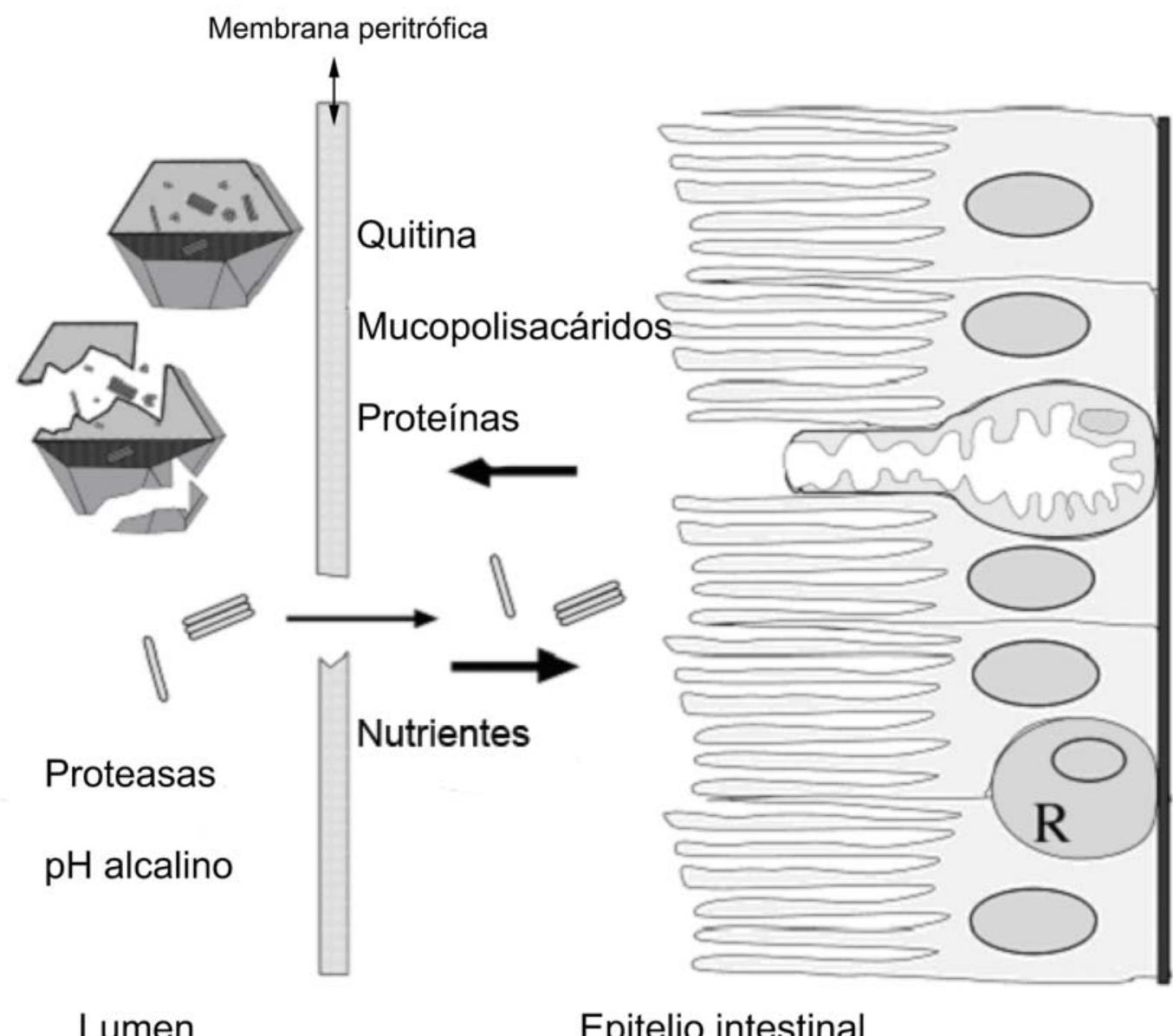

Fig.1.5. Esquema del intestino medio de un insecto con membrana peritrófica. Se muestra la presencia de cuerpos de oclusión baculovirales y su acción sobre la MP. R: células regenerativas del epitelio intestinal. (Fuente: Rohrmann 2008)

La MP está compuesta por quitina (poli $\beta(1,4)-\mathrm{N}$-acetil-D-glucosamina), la que representa entre el 3 y el 13\% de la misma (Lehane, 1997). El resto de la MP está formado por una mezcla de proteínas, glicoproteínas y proteoglicanos. Las proteínas constituyen entre el $20-55 \%$ del total de la masa en la PM (Zimmermann, 1975). Estas proteínas varían en tamaño desde 15 hasta 220 kDa. 
La función que posee la MP en el intestino medio es proteger la superficie del mismo de los daños causados por el material abrasivo, los alimentos y para limitar el acceso de los microorganismos. También permite la transferencia de sustancias líquidas y digeridas a las células epiteliales del intestino medio, pero impide el paso de las partículas de comida más grandes. Es desgastado por el paso de los alimentos y se regenera a partir de las células epiteliales.

El ciclo de los baculovirus se divide en dos etapas: la infección primaria y la infección secundaria. En los lepidópteros, el estado larval es el más susceptible. Las larvas ingieren los cuerpos de oclusión que se encuentran contaminando su alimento (Fig. 1.6).

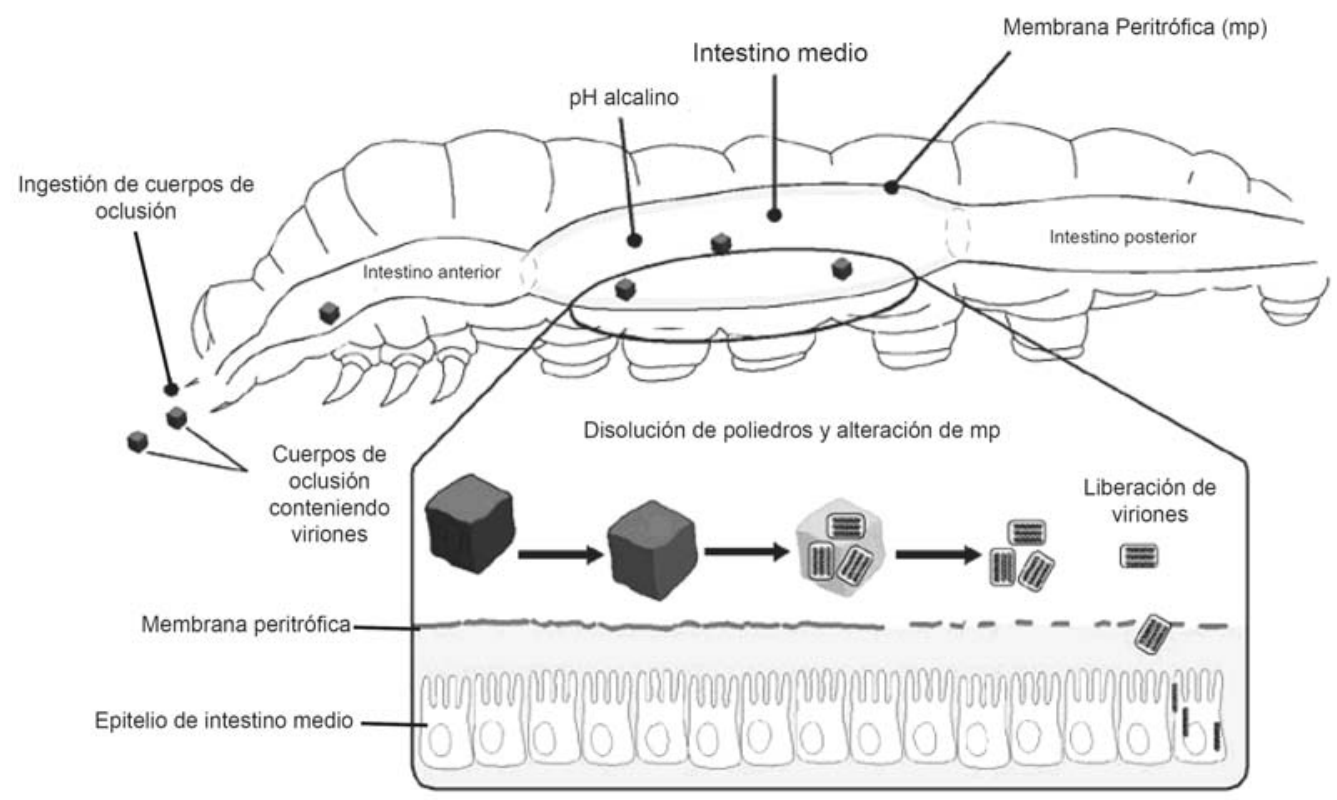

Fig. 1.6: Fase primaria de infección de un baculovirus (NPV)

Los $\mathrm{OB}$ ingeridos, al alcanzar el intestino medio, son rápidamente disueltos debido a la acción de proteasas alcalinas presentes en los jugos intestinales $(\mathrm{pH}>9.5)$ y se liberan los viriones derivados de los cuerpos de oclusión (ODV). La primera barrera 
que encuentran dichos viriones es la membrana peritrófica (Eisemann \& Binnington, 1994; Lehane, 1997).

Los viriones se unen luego a las microvellosidades del epitelio intestinal mediante la fusión de sus membranas, permitiendo que las nucleocápsides (NC) contenidas en su interior sean liberadas en el citosol (Flipsen et al., 1995). Es en esta etapa, cuando las proteínas presentes en la envoltura del ODV, como las anteriormente mencionadas P74 y PIFs, juegan un rol importante en la fusión a las células del intestino medio (Ohkawa et al., 2005).

Las NC liberadas en el citosol son transportadas al núcleo y el DNA desnudo entra por el poro nuclear iniciando la expresión y replicación del DNA (Granados \& Lawler, 1981) (Fig.1.7). La mayor parte de las proteínas necesarias para la replicación del DNA viral están incluidas en el ODV: DNA polimerasa, helicasas, IE1, LEF1 y LEF3 (Braunagel et al., 2003). La incorporación al azar dentro del ODV no está descartada, aunque es probable que este proceso sea altamente específico (Rohrmann, 2008). Una vez replicado el material genético e iniciada la cascada transcripcional de los genes virales que permite la formación de nuevas NC, estas salen del núcleo posiblemente por brotación llevando una envoltura procedente de la membrana nuclear que contiene al menos una proteína viral (GP16) (Gross et al., 1993). Esta membrana es posteriormente perdida en el citoplasma.

En la fase secundaria de la infección, las NC formadas son transportadas a la membrana celular, desde donde abandonan la célula por brotación o a través de la membrana basal. Previamente, grandes cantidades de proteínas virales (GP64 o proteína F) son acumuladas sobre la membrana celular que constituirá la envoltura del BV (Braunagel et al., 2003; Pearson et al., 2001b).

Los BV una vez que abandonan la célula migran a células vecinas, adonde entran por endocitosis, probablemente mediada por la interacción de GP64/F con un receptor de la superficie celular. Una vez que la vesícula endosomal es liberada en el citosol, el endosoma se acidifica, su membrana y la del BV se fusionan, liberando la nucleocápside en el citoplasma.

Durante la infección secundaria, en las infecciones producidas por NPV, los viriones que permanecen en el núcleo parecen obtener una membrana de microvesículas 
que tendría su origen en la membrana nuclear interna y que habría sido modificada por el agregado de proteínas virales especificas (Braunagel \& Summers, 2007). En esta etapa ocurre la hiperexpresión de genes tardíos resultando en altos niveles de producción de proteínas como $\mathrm{P} 10$ y poliedrina. Esta última se acumula en el núcleo rodeando a los viriones y se sabe que al menos una proteína (Ac68) interviene en este proceso de oclusión de los viriones dentro de la matriz proteica del cuerpo de oclusión (Xu et al., 2008a). La proteína P10 parece estar íntimamente involucrada en el ensamblado de la envoltura del poliedro sobre el cuerpo de oclusión (Rohrmann, 2008) (Fig. 1.7).

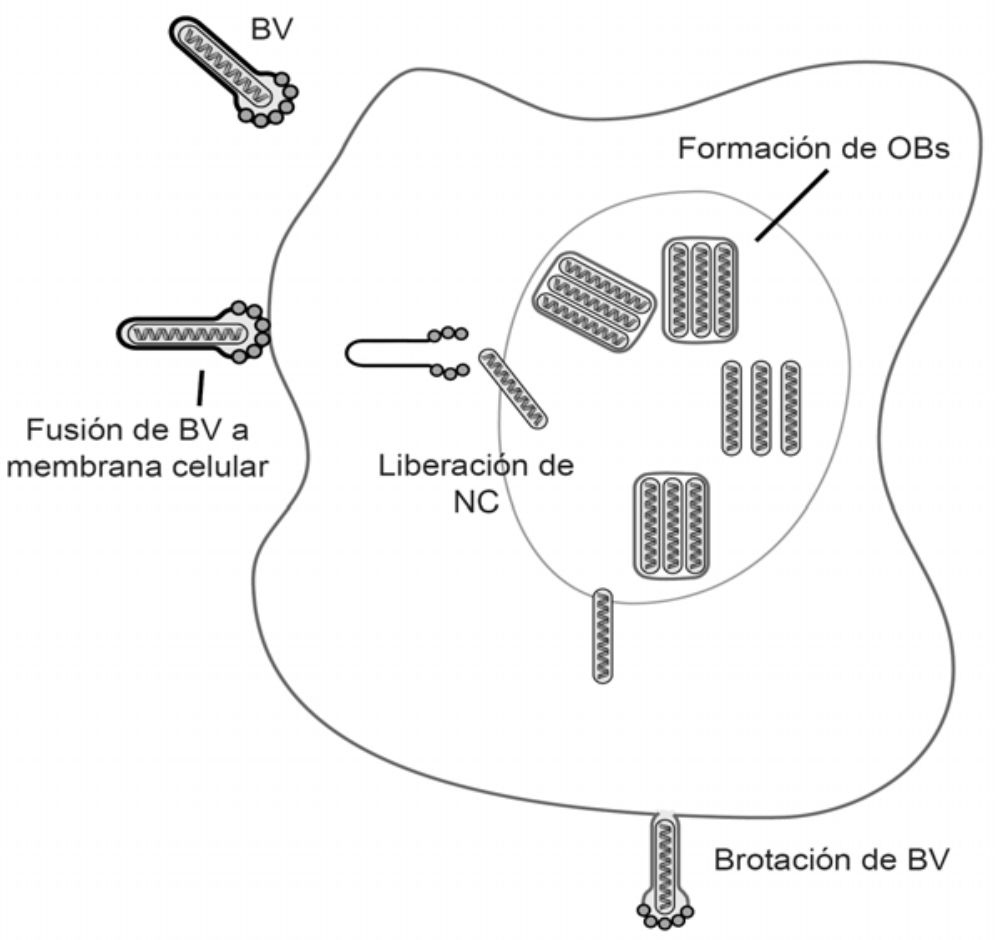

Fig. 1.7. Fase secundaria de infección. Viriones brotantes (BV) ingresan, mediante fusión de su membrana con la membrana celular, a células susceptibles dentro del hospedador en las cuales continuarán con la generación de BV y con la formación de cuerpos de oclusión (OB). Estos últimos serán liberados al medio posteriormente a la muerte y ruptura del tegumento del hospedador. 
Avanzada la infección se produce la lisis celular, adquiriendo la hemolinfa una característica coloración blanquecina debido a la acumulación de cuerpos de oclusión. En tal sentido, estudios realizados con AcMNPV, BmNPV y SeMNPV en células de insecto mostraron que este último proceso es dependiente de la presencia de $\mathrm{P} 10$, de la acción de una proteína quinasa y de catepsina codificadas por el virus (Williams et al., 1989; Van Oers et al., 1993; Lanier et al., 1996; Williams \& Faulkner, 1997). En infecciones in vivo, cuando la mayor parte de los tejidos susceptibles se ven afectados, el insecto muere. El tegumento de la larva se rompe y se liberan los OBs en el ambiente, ayudado este proceso por la acción de una quitinasa codificada por el mismo virus (Hawtin et al., 1995; Wang et al., 2005).

Los cuerpos de oclusión liberados estabilizan a los viriones en el exterior del huésped, permitiendo la transmisión horizontal de la infección cuando las larvas de insectos susceptibles ingieren alimento por ellos contaminados (Miller, 1996).

\section{Uso de baculovirus en el control biológico de plagas}

El control biológico de plagas se relaciona con el uso de los enemigos naturales: predadores, parásitos, parasitoides y patógenos. El manejo de patógenos de insectos (entomopatógenos) tiene como objetivo reducir las poblaciones y los efectos de las plagas.

Para que un patógeno sea efectivo como agente de control microbiano de plagas, debe reunir algunas características deseables, entre las que se encuentran alta virulencia, inocuidad hacia otras formas de vida (incluidos insectos benéficos, vertebrados y plantas), acción rápida, larga permanencia a campo y producción fácil y económica.

Los baculovirus junto con la bacteria esporulada Bacillus thuringiensis y algunas especies de hongos, representan los tres grupos de entomopatógenos que mayor atención han recibido para su desarrollo como bioinsecticidas (Tabla 1.1). A nivel mundial el uso de virus bioinsecticidas muestra diferencias regionales. Su uso en las regiones templadas de Europa, Estados Unidos y Canadá con sistemas de producción extensiva está limitado actualmente al control de plagas forestales y de frutales (Caballero et al, 2001). En cambio, la situación en los países en vías de 
desarrollo es más favorable y se destaca sobre todos, el programa de control de Anticarsia gemmatalis llevado a cabo en Brasil exitosamente por más de veinte años (Moscardi \& Sosa Gomez, 2007)

Tabla 1.1. Listado de plagas agronómicas y forestales controladas mediante el uso baculovirus incluidos en formulaciones comerciales. (Fuente: Control de Plagas Agrícolas. Autores: J.A. Jacas y A. Urbaneja Ed. Phytoma, 2008).

\begin{tabular}{|c|c|c|c|c|}
\hline Insecto & Virus & $\begin{array}{l}\text { Nombre del } \\
\text { bioinsecticida }\end{array}$ & Empresa & Cultivo \\
\hline Adoxophyes orana & GV & Capex & Andermatt Biocontrol AG & Manzano \\
\hline Anticarsia gemmatalis & NPV & $\begin{array}{l}\text { Baculo-Soja } \\
\text { Baculovirus Nitral } \\
\text { Coopervirus PM } \\
\text { Protege }\end{array}$ & $\begin{array}{l}\text { Nova Era Biotecnologia Agrícola } \\
\text { Nitral Urbana Laboratorios } \\
\text { Coop. Central Agropecuaria DTE } \\
\text { Milenio Agro Ciencias }\end{array}$ & Soja \\
\hline Autographa californica & NPV & VPN-80 & Agricola El Sol & $\begin{array}{l}\text { Hortalizas, } \\
\text { algodón, etc. }\end{array}$ \\
\hline Cydia pomonella & GV & $\begin{array}{l}\text { Carpovirusine } \\
\text { Madex } \\
\text { CYD-X }\end{array}$ & $\begin{array}{l}\text { Natural Plant Protection } \\
\text { Andermatt Biocontrol AG } \\
\text { Certis }\end{array}$ & $\begin{array}{l}\text { Manzano } \\
\text { y Peral }\end{array}$ \\
\hline Cryptophlebia leucotreta & GV & Cryptex & Andermatt Biocontrol AG & Citricos, algodón \\
\hline Erinnyis ello & GV & - & Biocaribe SA & Yuca \\
\hline Helicoverpa armigera & NPV & $\begin{array}{l}\text { Helicovex } \\
\text { Heliokill }\end{array}$ & $\begin{array}{l}\text { Andermatt Biocontrol AG } \\
\text { Ajay Bio-Tech }\end{array}$ & $\begin{array}{l}\text { Hortalizas, } \\
\text { algodón }\end{array}$ \\
\hline H. zea y Heliothis virescens & NPV & $\begin{array}{l}\text { Elcar } \\
\text { GemStar LC }\end{array}$ & $\begin{array}{l}\text { Sandoz } \\
\text { Certis }\end{array}$ & $\begin{array}{l}\text { Algodón, } \\
\text { hortalizas, etc. }\end{array}$ \\
\hline Hyphantria cunea & NPV & Virin-ABB & & Forestales \\
\hline Lymantria dispar & NPV & $\begin{array}{l}\text { Gypchek } \\
\text { Disparvirus } \\
\text { Virin-ENSh }\end{array}$ & $\begin{array}{l}\text { USDA ForestService } \\
\text { Corporation CCIP Inc. }\end{array}$ & Forestales \\
\hline Mamestra brassicae & NPV & $\begin{array}{l}\text { Mamestrin } \\
\text { Virin-EKS }\end{array}$ & Natural Plant Protection & Hortalizas \\
\hline Mamestra configurata & NPV & Virosoft CP4 & Biotepp Inc. & Manzano \\
\hline Neodripion sertifer y $N$. lecontei & NPV & $\begin{array}{l}\text { Virox } \\
\text { Neochek S } \\
\text { Leconteivirus }\end{array}$ & $\begin{array}{l}\text { Microbial Resources } \\
\text { USDA Forest Service } \\
\text { Canadian Forest Service }\end{array}$ & Forestales \\
\hline Orgya pseudotsugata & NPV & $\begin{array}{l}\text { TM Biocontrol-1 } \\
\text { Virtuss }\end{array}$ & $\begin{array}{l}\text { USDA Forest Service } \\
\text { Corporation CCIP Inc. }\end{array}$ & $\begin{array}{l}\text { Forestales, } \\
\text { ornamentales }\end{array}$ \\
\hline Phthorimaea operculella & GV & PTM baculovirus & Varias & Patatas \\
\hline Pieris rapae & GV & - & Wuhan University & Hortalizas \\
\hline Spodoptera exigua & NPV & $\begin{array}{l}\text { Spod-X } \\
\text { Spexit } \\
\text { Ness-E }\end{array}$ & $\begin{array}{l}\text { Certis } \\
\text { Andermatt Biocontrol AG } \\
\text { Applied Chem. Thail. }\end{array}$ & $\begin{array}{l}\text { Hortalizas, } \\
\text { ornamentales }\end{array}$ \\
\hline Spodoptera frugiperda & NPV & - & Embrapa & Maiz, sorgo \\
\hline Spodoptera littoralis & NPV & Spodopterin & Natural Plant Protection & $\begin{array}{l}\text { Hortalizas, } \\
\text { algodón, etc. }\end{array}$ \\
\hline Spodoptera litura & NPV & Yro & Zhongshan University & $\begin{array}{l}\text { Hortalizas, } \\
\text { algodón, arroz }\end{array}$ \\
\hline Spodoptera sunia & NPV & VPN-82 & Agrícola El Sol & Hortalizas \\
\hline
\end{tabular}


En nuestro país, durante la campaña 2003 se realizó en el Valle Inferior del Río Negro (Prov. de Río Negro), la primera experiencia de control de la plaga de manzanos y perales "carpocapsa" (Cydia pomonella) mediante el uso del granulovirus homónimo (CpGV). El producto utilizado fue Carpovirus Plus, registrado en la Argentina por el INTA. Durante más de 7 años, se desarrolló un trabajo intensivo y sostenido de evaluación de la eficacia de control en las distintas regiones productoras de nuestro país. Dados los resultados positivos de su aplicación, su uso sigue en aumento. Más recientemente fue aprobado el registro para el uso experimental de una formulación a base de Epinotia aporema Granulovirus (EpapGV) (exp. SENASA E241).

\section{Lepidópteros plaga de importancia agronómica regional y agentes de biocontrol utilizados.}

\section{Epinotia (=Crocidosema) aporema (Wals)}

Conocido vulgarmente como "barrenador de los brotes del soja", es un insecto incluido en el Orden Lepidoptera, Familia Tortricidae. Esta plaga se encuentra distribuida en Centro y Sudamérica. Ataca diversas leguminosas de importancia económica tales como el poroto, arvejas, garbanzo, soja, maní y alfalfa (Villata \& Ayessa, 1994).

Es considerada como una de las plagas claves o principales en las leguminosas cultivadas. Los daños en los cultivos los realizan los estadios larvales que inicialmente raspan la superficie de la epidermis de los foliolos y luego barrenan el brote terminal y principal de las leguminosas. En poroto y soja, en caso de una fuerte infestación, daña también los brotes laterales, los que se secan y mueren; posteriormente perforan el tallo en el ápice, penetrando en él y formando canales hacia abajo. Como consecuencia de sus ataques las plantas infestadas paralizan su desarrollo y quedan raquíticas, produciendo vainas muy pequeñas y de mala calidad.

Exteriormente la infestación se manifiesta por los excrementos que son expulsados hacia fuera del canal y por la deformación del los folíolos de los brotes, que se 
encuentran unidos por hilos de seda (Fig. 1.8). También pueden alimentarse de hojas, vainas e inclusive flores. Un daño secundario es la entrada de microorganismos a la vaina a través de los orificios que las larvas realizan al penetrar en ellas (Liljesthröm \& Rojas-Fajardo, 2005)

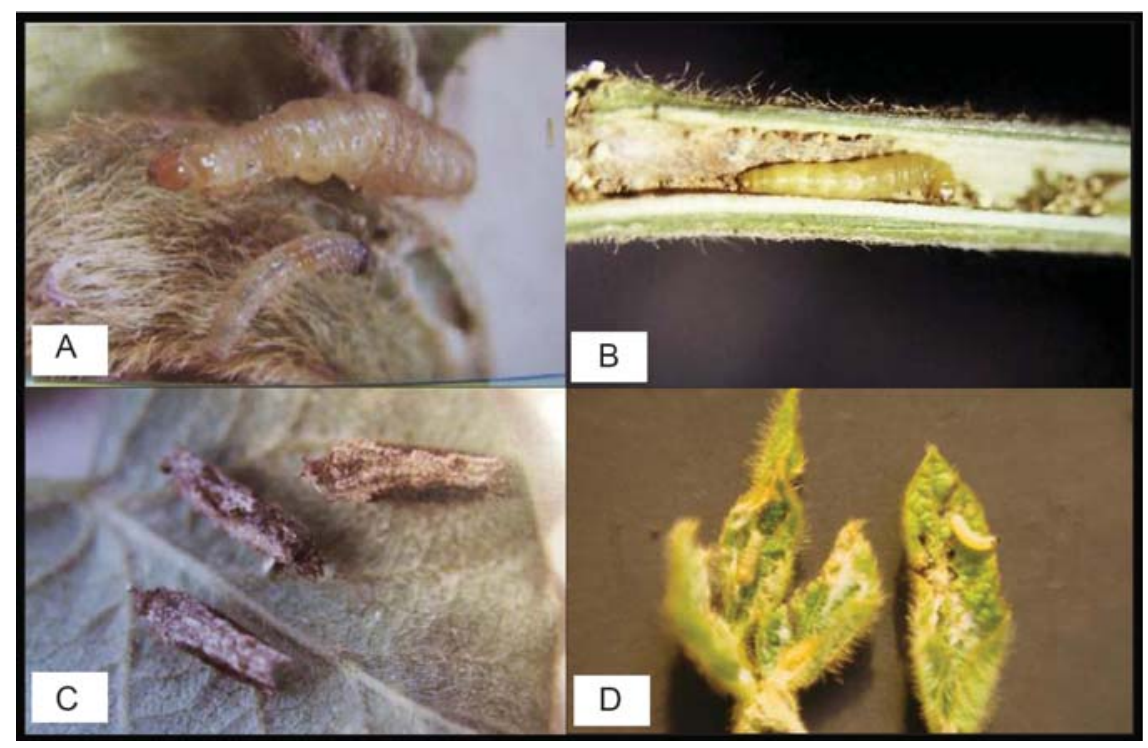

Fig. 1.8. Epinotia aporema (Walls). (Fuente: www.inta.gov.ar/imyza/index.

A. Estadios larvales sobre hojas del cultivo de soja. B. Larva barrenando tallo de leguminosas. C. Adultos. D. Daño producido en brotes y hojas de soja.

En nuestro país, el daño producido por esta plaga en cultivos de soja representa el segundo en importancia económica, determinándose pérdidas de un rendimiento de hasta $40 \%$. En la actualidad, se utilizan para su control insecticidas químicos de amplio espectro y alta toxicidad, que además de ser contaminantes, limitan la implementación de un correcto manejo integrado de plagas debido a su escasa selectividad. 


\section{Virus de la granulosis de Epinotia aporema}

En el año 1982 se colectaron por primera vez en Chile, larvas de Epinotia aporema muertas con signos característicos de infección viral (Ripa, 1982). Posteriormente, investigadores de la EEA INTA Oliveros (Santa Fe), llevaron a cabo estudios sobre la dinámica poblacional de la plaga en cultivos de soja e identificaron sus principales agentes de control biológico natural. Producto de dichas investigaciones, se detectó un baculovirus con alta incidencia en la mortalidad natural de larvas de dicha especie (Diaz y Diez, 1989)

Mediante trabajos conjuntos entre el IBBM (CONICET, UNLP) y el IMYZA (INTA, Castelar) se realizó la caracterización morfológica y bioquímica de un aislamiento a partir de larvas muertas de E. aporema colectadas en Oliveros, al cual se lo denominó Epinotia aporema Granulovirus (EpapGV) (Sciocco-Cap et al., 2001; Goldberg et al., 2002) (Fig 1.9)

El virus fue evaluado bajo condiciones controladas y se establecieron metodologías para el control de la calidad de un formulado insecticida a base de EpapGV (Parola et al., 2003; Manzán et al., 2008). Sobre la base de esos antecedentes, se obtuvo ante SENASA el registro de uso experimental de una formulación para el control de este insecto plaga (SENASA E-256). Además, se obtuvo un mapa físico y una secuencia parcial del genoma, caracterizándose funcionalmente algunos genes de interés (Manzán et al., 2002; Parola et al., 2003). 


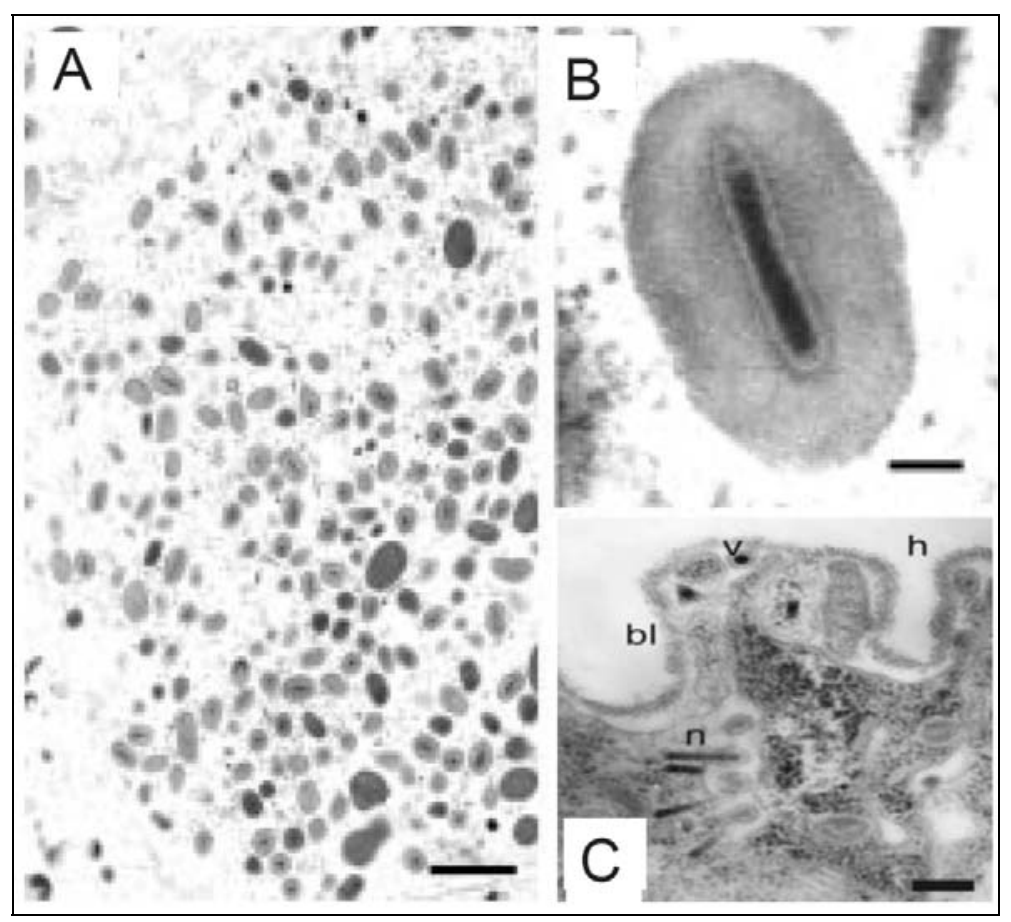

Fig. 1.9. Estudios de miscroscopía para la caracterización de EpapGV (Fuente: Sciocco et al., 2001 y Goldberg et al., 2002). A: Corte de células epidérmicas mostrando viriones y gránulos (barra, $1 \mathrm{~mm}$ ). B: Sección longitudinal de un OB (barra, $100 \mathrm{~nm}$ ). C. Nucleocápsides (n) brotando de estructuras vesiculares. Lámina basal (bl), virión (v), Hemolinfa (h).

\section{Orugas defoliadoras}

\section{Anticarsia gemmatalis (Hübner)}

Fue descripta por primera vez en 1903 en Florida (Hinds, 1931). Se la encuentra en todo el continente americano y es una plaga principal en los cultivos de soja en Brasil. En nuestro país, se encuentra en la región Pampeana, Mesopotamia y Norte (Fig.1.10). Las mayores infestaciones se han producido en las provincias de Córdoba y Santa Fe (lannone, 2007) coincidente con la mayor área sembrada de soja, su planta predilecta. Además, puede encontrarse en maní, alfalfa, poroto y otras plantas diferentes a leguminosas que incluyen el algodón, trigo, lino y algunas hortalizas. Las hembras depositan entre 900 y 1000 huevos, en forma aislada, en el envés de las hojas. La oruga llega a medir 35 a $40 \mathrm{~mm}$ de largo y se presenta en dos formas: una de color verde intenso y otra de color verde oscuro a negro, con 
una serie de líneas longitudinales blancas. Presentan 6 estadios y requieren 15 a 20 días para alcanzar su máximo desarrollo (Aragón et al., 1998).

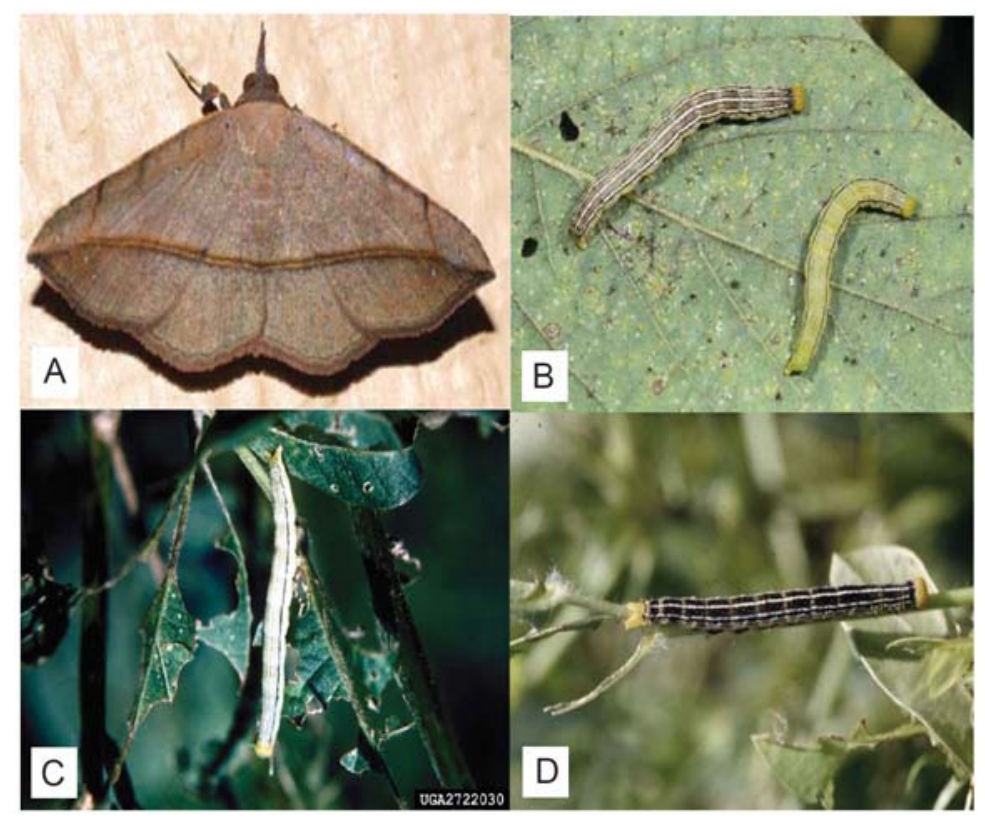

Fig. 1.10. Anticarsia gemmatalis. A: Adulto; B: larvas de quinto estadio. C y D: daño foliar producido por las larvas

Las larvas de primer estadio se alimentan del parénquima foliar, dejando la epidermis superior de las hojas casi intacta. En el segundo estadio, se alimentan de la porción intermedia del tejido y de las nervaduras más pequeñas. A medida que aumenta su desarrollo su voracidad también se incrementa (Gutierrez, 1978).

Las larvas son esencialmente filófagas, pero en ocasiones atacan también las vainas que aún no formaron granos. Una larva llega a consumir entre 100 y $110 \mathrm{~cm}^{2}$ de hojas de soja, también pueden dañar, total o parcialmente, vainas tiernas (Flores, 2006).

Sumados a los controles culturales y químicos existen herramientas de control biológico. La utilización a campo en gran escala de aislamientos de un baculovirus, denominado Anticarsia gemmatalis Nucleopolyhedrovirus (AgMNPV), ha hecho de este virus el más utilizado a nivel mundial (Oliveira et al., 2006) . 


\section{Nucleopoliedrovirus de Anticarsia gemmatalis (AgMNPV)}

Este virus fue aislado en Brasil en el año 1977 y desde 1980 es utilizado como bionsecticida y aplicado en forma extensiva (Fig.1.11).

AgMNPV es principalmente infectivo hacia $A$. gemmatalis, aunque otras especies como Pseudoplusia includens, Rachiplusia nu y Spodoptera sp., resultan ser susceptibles pero a dosis que resultan antieconómicas en aplicaciones en campo.

El proceso de infección desde su inicio hasta la muerte en la larva dura entre seis y siete días, pero al tercer día prácticamente deja de alimentarse y sus movimientos se reducen al mínimo, dirigiéndose generalmente a la parte superior de la planta, donde queda colgada de las falsas patas abdominales o espuripedios, en posición muy característica.

En los primeros dos días después de la muerte, la larva presenta un color amarillocremoso, el cual se va oscureciendo hasta quedar completamente negro; es en esta fase se produce la ruptura del tegumento, liberando gran cantidad de poliedros sobre la superficie foliar, que van a servir como fuente de inóculo para infectar a otras larvas presentes en el cultivo.

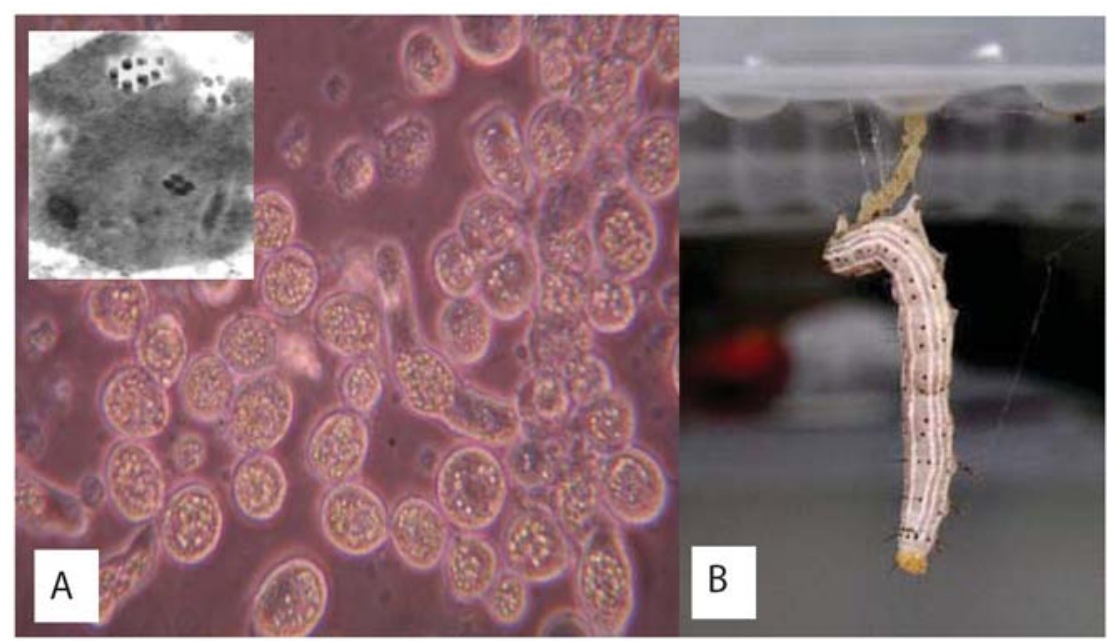

Fig.1.11. A: Microscopia electrónica de transmisión de un corte ultrafino de un poliedro de AgMNPV y células (UFIAg-286) infectadas con AgMNPV, observadas bajo microscopio óptico. B: larva de Anticarsia gemmatalis muerta por acción de AgMNPV. 
Recientemente se publicó la secuencia completa del genoma de AgMNV (Oliveira et al., 2006) lo que facilitará el diseño de modificaciones que optimicen su acción insecticida.

\section{Spodoptera frugiperda (Smith)}

La "oruga cogollera", Spodoptera frugiperda (Smith) (Lepidoptera: Noctuidae), es una especie polifitófaga nativa del trópico, con amplia distribución geográfica, desde Argentina y Chile, hasta el sur de Estados Unidos. En maíz, prefiere hojas y brotes tiernos, especialmente los cogollos (Fig.1.12). Entre los cultivos frecuentemente atacados se destacan entre otros, algodón, sorgo, soja, girasol y maíz. (Alonso Alvarez, 1991; Murillo, 1991). Es la plaga principal del noroeste y noreste argentino (Willink y col., 1990). Los maíces de siembra tardía son los más afectados y se requieren hasta 3 aplicaciones de insecticidas para controlar la plaga (Sosa, 2002). Las larvas son activas de noche y de día, atacan a la planta de maíz actuando como cortadoras, defoliadoras y cogolleras según el momento de su desarrollo, produciendo daños directos cuando se alimentan de los granos de la espiga (Willink y col., 1993).

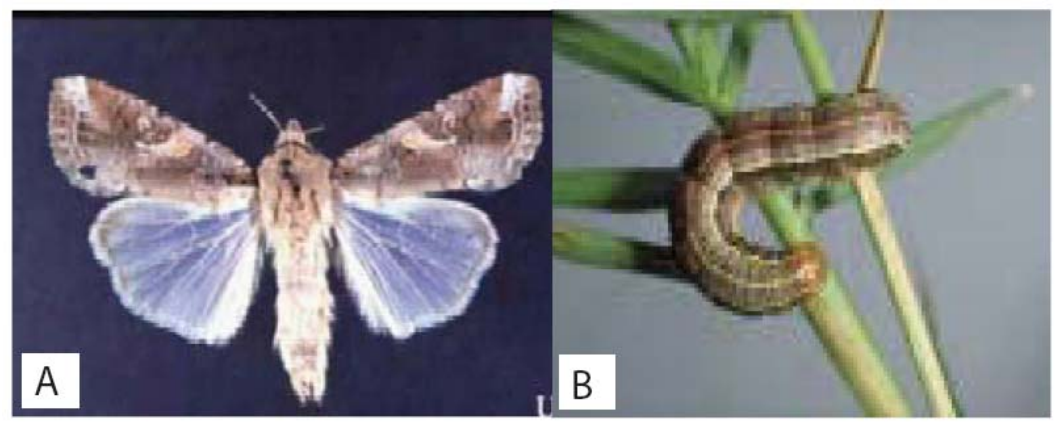

Fig. 1.12. Spodoptera frugiperda (J.E. Smith) (Lepidoptera: Noctuidae).

A: Adulto; B: Larva de cuarto estadio (Fotos: J. L. Capinera, USDA).

Esta plaga presenta 6 a 8 estadios en su estado larval. Durante los dos primeros, las larvas roen la epidermis de las hojas, dejando manchas translúcidas; a partir del tercero, consumen toda la lámina foliar dejando huecos irregulares en el follaje, luego migran hacia el cogollo, donde encuentran protección. Por otra parte a esa edad, tienen hábitos caníbales, razón por la cual se encuentra una sola por cogollo. 
El mayor consumo, $80 \%$ de la ingesta, lo realizan en los dos últimos estadios (Alonso Alvarez, 1991). El control de la plaga en nuestro país se realiza mediante agentes químicos y prácticas culturales.

\section{Contexto de trabajo}

Los baculovirus son utilizados como agentes de control de plagas agrícolas y forestales. Actualmente existe la posibilidad de modificarlos genéticamente con el objeto de aumentar su eficacia como agentes insecticidas. Desde el punto de vista teórico se consideran dos tipos de modificaciones: por un lado, disminuir su especificidad, es decir ampliar su rango de hospedantes y por otro, modificar los factores de eficacia insecticida del virus, es decir la velocidad de acción y la dosis efectiva. Centrándonos en este último punto de vista, existen antecedentes que demuestran la existencia de factores proteicos codificados en algunos baculovirus, los cuales son capaces de incrementar su acción insecticida. Estos factores fueron descubiertos mediante el uso de mezclas virales, que evidenciaron el incremento de la patogenicidad de uno de los virus (Derksen \& Granados, 1988; Lepore et al., 1996; Peng et al., 1999; Slavicek \& Popham, 2005; Tanada et al., 1973; Wang \& Granados, 1997; Wang et al., 2004)

La utilización de mezclas virales permite determinar el tipo de interacción que se establece entre los agentes virales utilizados y, a su vez, buscar los agentes proteicos responsables del efecto observado.

\section{Hipótesis}

Mediante trabajos conjuntos entre el IBBM y el IMYZA (INTA) se realizó la caracterización biológica y molecular del granulovirus Epinotia aporema (EpapGV), el cual se encuentra bajo registro de uso experimental como bioinsecticida (Goldberg, 2003; Goldberg et al., 2002; Parola, 2004; Parola et al., 2002; ScioccoCap et al., 2001). Según resultados preliminares de ensayos realizados por nuestro equipo de investigación, la administración conjunta de EpapGV y AgMNPV potencia 
la actividad insecticida de AgMNPV en larvas de la especie homónima acortando el tiempo letal. Debido a que EpapGV no sería infectivo hacia $A$. gemmatalis, se postula que tal incremento en la virulencia podría estar asociado a la presencia de ciertas proteínas presentes en las preparaciones de cuerpos de oclusión de EpapGV.

En este contexto, los objetivos incluyen la búsqueda y caracterización de genes asociados a la virulencia en EpapGV, el estudio de su función en el ciclo de infección viral mediante la generación de recombinantes de AcMNPV y el desarrollo de estrategias que permitan optimizar la utilización a campo de EpapGV, aislado o en combinación con AgMNPV.

El análisis del genoma de AgMNPV recientemente publicado muestra que posee 132239 pb y codifica 152 marcos de lectura abiertos (Open Reading Frames: ORF) (Oliveira et al., 2006). En este genoma se encuentran ausentes los genes gp37, chiA y $v$-cath que se han hallado dispuestos en bloque en el genoma de EpapGV.

En base a los antecedentes resumidos en la Introducción, a las diferencias en contenidos génicos y a los resultados preliminares mencionados, se espera poder utilizar al sistema AgMNPV-A. gemmatalis como sistema modelo para el estudio de estos genes de EpapGV y sus productos, a fin de evaluar su potencial de utilización en el mejoramiento de la eficacia insecticida del mismo y otros Nucleopolyhedrovirus de importancia agrícola. A diferencia de otros sistemas modelo, tanto AgMNPV como EpapGV son patógenos de plagas de interés agronómico.

Es dentro de este contexto que surge el plan de trabajo de Tesis y los objetivos generales y particulares planteados. 


\section{Objetivo general de la Tesis}

Caracterización biológica y molecular de genes involucrados en la virulencia de baculovirus y utilización de los mismos para el mejoramiento genético de virus de importancia agronómica en nuestro país.

\section{Objetivos Particulares}

- Evaluación de la interacción de los virus de EpapGV y AgMNPV en mezclas virales aplicadas sobre larvas de Anticarsia gemmatalis y Epinotia aporema.

- Identificación, clonado, secuenciación y estudio funcional de genes de EpapGV relacionados con la virulencia y con posible actividad potenciadora de la infección.

- Generación de virus recombinantes (rAcMNPV y AgMNPV) que expresen genes candidatos para el mejoramiento genético de su eficacia insecticida. 


\section{Referencias}

Afonso, C. L., Tulman, E. R., Lu, Z., Balinsky, C. A., Moser, B. A., Becnel, J. J., Rock, D. L. \& Kutish, G. F. (2001). Genome sequence of a baculovirus pathogenic for Culex nigripalpus. J Virol 75, 11157-11165.

Alonso Alvarez, R. 1991. Reseña histórica y aspectos bioecológicos del gusano cogollero del maíz Spodoptera frugiperda (J. E. Smith). In Memorias Seminario Spodoptera frugiperda (El gusano cogollero) en sorgo, maíz y otros cultivos. Zuluaga, J. L. Muñoz, G. (comp., ed.) Calí, Colombia 96p. Pag. 12-14.

Bergold, G. H. (1952). Demonstration of the polyhedral virus in blood cells of silkworms. Biochim Biophys Acta 8, 397-400.

Braunagel, S. C., Russell, W. K., Rosas-Acosta, G., Russell, D. H. \& Summers, M. D. (2003). Determination of the protein composition of the occlusion-derived virus of Autographa californica nucleopolyhedrovirus. Proc Natl Acad Sci U S A 100, 97979802.

Braunagel, S. C. \& Summers, M. D. (2007). Molecular biology of the baculovirus occlusionderived virus envelope. Curr Drug Targets 8, 1084-1095.

Caballero, P., Lopez-Ferber, M. \& Williams, T. (2001). Los baculovirus y sus aplicaciones bioinsecticidas en el control biologico de plagas. Universidad Pública de NavarraPhytoma, España, 518 pp.

Cheley, S., Kosik, K. S., Paskevich, P., Bakalis, S. \& Bayley, H. (1992). Phosphorylated baculovirus p10 is a heat-stable microtubule-associated protein associated with process formation in Sf9 cells. J Cell Sci 102 ( Pt 4), 739-752.

Derksen, A. C. \& Granados, R. R. (1988). Alteration of a lepidopteran peritrophic membrane by baculoviruses and enhancement of viral infectivity. Virology 167, 242-250. 
Diaz, B. D., S. (1989). Presencia de un virus de la granulosis en larvas de Epinotia aporema (Wals.),en cultivos de soja. In IV Conferencia Mundial de Investigación en soja, pp 1588-1592 Buenos Aires, Argentina

Dow, J. A. (1992). pH gradients in lepidopteran midgut. J Exp Biol 172, 355-375.

Eisemann, C. H. \& Binnington, K. C. (1994). The peritrophic membrane: its formation, structure, chemical composition and permeability in relation to vaccination against ectoparasitic arthropods. Int J Parasitol 24, 15-26.

Flipsen, J. T., Martens, J. W., van Oers, M. M., Vlak, J. M. \& van Lent, J. W. (1995). Passage of Autographa californica nuclear polyhedrosis virus through the midgut epithelium of Spodoptera exigua larvae. Virology 208, 328-335.

Flores, J. R. A. y. F. (2006). Control integrado de plagas en soja en el sudeste de Córdoba.

Funk, J., Braunagel, S. C. \& Rohrmann, G.F. 1997. Baculovirus structure. pp. 7-32. En: The Baculoviruses. L. Miller (ed.). Plenum Press, New York

Goldberg, A. V. (2003). Estudio biológico y molecular del proceso de infección de un virus de la granulosis de Epinotia aporema y evaluación de su potencial como agente de control biológico. Tesis Facultad de Ciencias Exactas y Naturales. Universidad Nacional de Buenos Aires

Goldberg, A. V., Romanowski, V., Federici, B. A. \& Sciocco de Cap, A. (2002). Effects of the Epap granulovirus on its host, Epinotia aporema (Lepidoptera: Tortricidae). J Invertebr Pathol 80, 148-159.

Granados, R. R. \& Lawler, K. A. (1981). In vivo pathway of Autographa californica baculovirus invasion and infection. Virology 108, 297-308.

Gross, C. H., Russell, R. L. \& Rohrmann, G. F. (1994). Orgyia pseudotsugata baculovirus p10 and polyhedron envelope protein genes: analysis of their relative expression levels and role in polyhedron structure. J Gen Virol 75 ( Pt 5), 1115-1123. 
Gross, C. H., Wolgamot, G. M., Russell, R. L., Pearson, M. N. \& Rohrmann, G. F. (1993). A baculovirus encoded 16-kDa glycoprotein localizes near the nuclear membrane of infected cells. Virology 192, 386-390.

Gutierrez, B. P., J. (1978). Ciclo de vida y hábitos de Anticarsia gemmatalis plaga de la Boya en el Valle del Cauca. Rev Colomb Entomol 4, 3-9.

Hashimoto, Y., Corsaro, B. G. \& Granados, R. R. (1991). Location and nucleotide sequence of the gene encoding the viral enhancing factor of the Trichoplusia ni granulosis virus. J Gen Virol 72 ( Pt 11), 2645-2651.

Hinds, W. O. (1931). The soybean caterpillar in Louisiana. Journal of Economic Entomology $24,1168-1173$.

lannone, N. (2007). Alerta! Plaga de la soja. http://www.elsitioagricola.com/plagas/intaperga 20070117soja.asp

Jehle, J. A., Blissard, G. W., Bonning, B. C., Cory, J. S., Herniou, E. A., Rohrmann, G. F., Theilmann, D. A., Thiem, S. M. \& Vlak, J. M. (2006). On the classification and nomenclature of baculoviruses: a proposal for revision. Arch Virol 151, 1257-1266.

Kalmakoff, J. K., J. M. (1982). Enzootic virus control of Wiseana spp. in the pasture environment. . In Microbial and Viral Pestides, pp 435-448 Edited by G Kurstak New York: Marcel Dekker

Lapointe R. Characterization of two Autographa californica nucleopolyhedrovirus proteins, Ac145 and Ac150, which affect oral infectivity in a host-dependent manner. J Virol 2004;78(12):6439-48.

Lehane, M. J. (1997). Peritrophic matrix structure and function. Annu Rev Entomol 42, 525 550.

Lepore, L. S., Roelvink, P. R. \& Granados, R. R. (1996). Enhancin, the granulosis virus protein that facilitates nucleopolyhedrovirus (NPV) infections, is a metalloprotease. $J$ Invertebr Pathol 68, 131-140. 
Liljesthröm, G. \& Rojas-Fajardo, G. (2005). Parasitismo larval de Crocidosema (=Epinotia) aporema (Lepidoptera: Tortricidae) en el noreste de la provincia de Buenos Aires (Argentina). Revista de la Sociedad Entomológica Argentina 64, 37-44.

McCarthy, C. B. \& Theilmann, D. A. (2008). AcMNPV ac143 (odv-e18) is essential for mediating budded virus production and is the 30th baculovirus core gene. Virology $375,277-291$.

Minion (1979). Characterization of the polyhedral envelope of the nuclear polyhedrosis virus of Heliothis virescens. . J Invertebr Pathol 34:303-307.

Monsma, S. A., Oomens, A. G. \& Blissard, G. W. (1996). The GP64 envelope fusion protein is an essential baculovirus protein required for cell-to-cell transmission of infection. $J$ Virol 70, 4607-4616.

Moscardi, F. and S. Gomez. D. (2007). Microbial control of insect pest of soybean. Chapter VII-5, pp 411-426. En: Field Manual of Techniques in Insect Pathology, H Kaya and L Lacey (eds).Springer. The Netherlands.

Murillo, A. 1991. Distribución, importancia y manejo del complejo Spodoptera en Colombia. In Memorias Seminario Spodoptera frugiperda (El gusano cogollero) en sorgo, maíz y otros cultivos. Zuluaga, J. L. Muñoz, G. (comp., ed.). Calí. Colombia 96p. Pag. 1523.

Ohkawa, T., Washburn, J. O., Sitapara, R., Sid, E. \& Volkman, L. E. (2005). Specific binding of Autographa californica M nucleopolyhedrovirus occlusion-derived virus to midgut cells of Heliothis virescens larvae is mediated by products of pif genes Ac119 and Ac022 but not by Ac115. J Virol 79, 15258-15264.

Oliveira, J. V., Wolff, J. L., Garcia-Maruniak, A., Ribeiro, B. M., de Castro, M. E., de Souza, M. L., Moscardi, F., Maruniak, J. E. \& Zanotto, P. M. (2006). Genome of the most widely used viral biopesticide: Anticarsia gemmatalis multiple nucleopolyhedrovirus. J Gen Virol 87, 3233-3250. 
Olszewski, J. \& Miller, L. K. (1997). A role for baculovirus GP41 in budded virus production. Virology 233, 292-301.

Oomens, A. G., Monsma, S. A. \& Blissard, G. W. (1995). The baculovirus GP64 envelope fusion protein: synthesis, oligomerization, and processing. Virology 209, 592-603.

Paillot, A. (1926). Sur une nouvelle maladie du noyau au grasserie des chenilles de P. brassicae et un nouveau groupe de microoganismes parasites. Compt Rend $1926 ; 182: 180-2$

Parola, A. D. (2004). Caracterización molecular de un virus de la granulosis de Epinotia aporema. Tesis Doctoral; Universidad Nacional de La Plata.

Parola, A. D., Manzan, M. A., Lozano, M. E., Ghiringhelli, P. D., Sciocco-Cap, A. \& Romanowski, V. (2002). Physical and genetic map of Epinotia aporema granulovirus genome. Virus Genes 25, 329-341.

Pearson, M. N., Russell, R. L. \& Rohrmann, G. F. (2001a). Characterization of a baculovirus-encoded protein that is associated with infected-cell membranes and budded virions. Virology 291, 22-31.

Pearson, M. N., Russell, R. L. \& Rohrmann, G. F. (2001b). Characterization of a baculovirus-encoded protein that is associated with infected-cell membranes and budded virions. Virology 291, 22-31.

Peng, J., Zhong, J. \& R, R. G. (1999). A baculovirus enhancin alters the permeability of a mucosal midgut peritrophic matrix from lepidopteran larvae. J Insect Physiol 45, 159166.

Perera, O. P., Valles, S. M., Green, T. B., White, S., Strong, C. A. \& Becnel, J. J. (2006). Molecular analysis of an occlusion body protein from Culex nigripalpus nucleopolyhedrovirus (CuniNPV). J Invertebr Pathol 91, 35-42.

Peters, W. (1992). Peritrophic Membranes. Berlin. Springer. 1st ed.

Ripa, R. (1982). Presencia de dos nuevos patógenos en Epinotia aporema Wals. . Agricultura Técnica 41,55-56 
Rohrmann, G. (2008). Introduction to the baculoviruses and their taxonomy. www.ncbi.nlm.nih.gov/bookshelf/picrender.fcgi?book=bacvir...pdf

Sciocco-Cap, A., Parola, A. D., Goldberg, A. V., Ghiringhelli, P. D. \& Romanowski, V. (2001). Characterization of a granulovirus isolated from Epinotia aporema Wals. (Lepidoptera: Tortricidae) larvae. Appl Environ Microbiol 67, 3702-3706.

Slavicek, J. M. \& Popham, H. J. (2005). The Lymantria dispar nucleopolyhedrovirus enhancins are components of occlusion-derived virus. J Virol 79, 10578-10588.

Sosa, M. A. (2002). Estimación de daño de Spodoptera frugiperda Smith (Lepidoptera: Noctuidae) en maíz con infestación natural en tres fechas de siembra en el noreste santafesino. INTA. EEA Reconquista - Setiembre 2002

Tanada, Y., Himeno, M. \& Omi, E. M. (1973). Isolation of a factor, from the capsule of a granulosis virus, synergistic for a nuclear-polyhedrosis virus of the armyworm Pseudaletia unipuncta. J Invertebr Pathol 21, 31-40.

van Oers, M. M. \& Vlak, J. M. (2007). Baculovirus genomics. Curr Drug Targets 8, 10511068.

Vanarsdall, A. L., Pearson, M. N. \& Rohrmann, G. F. (2007). Characterization of baculovirus constructs lacking either the Ac 101, Ac 142, or the Ac 144 open reading frame. Virology 367, 187-195.

Vigdorovich, V., Miller, A. D. \& Strong, R. K. (2007). Ability of hyaluronidase 2 to degrade extracellular hyaluronan is not required for its function as a receptor for jaagsiekte sheep retrovirus. J Virol 81, 3124-3129.

Villata, C. A. A., A. M Ayessa. (1994). Manejo integrado de plagas en soja. Agro de Cuyo 7 , 71.

Wang, P. \& Granados, R. R. (1997). An intestinal mucin is the target substrate for a baculovirus enhancin. Proc Natl Acad Sci U S A 94, 6977-6982. 
Wang, P., Li, G. \& Granados, R. R. (2004). Identification of two new peritrophic membrane proteins from larval Trichoplusia ni: structural characteristics and their functions in the protease rich insect gut. Insect Biochem Mol Biol 34, 215-227.

Waterhouse (1953). The occurrence and significance of ther peritrophic membrane, with special reference to adult Lepidoptera and Diptera.Aust. J. Zool. .

Whitford, M. \& Faulkner, P. (1992). A structural polypeptide of the baculovirus Autographa californica nuclear polyhedrosis virus contains O-linked $\mathrm{N}$-acetylglucosamine. J Virol $66,3324-3329$.

Whitt, M. A. \& Manning, J. S. (1988). A phosphorylated 34-kDa protein and a subpopulation of polyhedrin are thiol linked to the carbohydrate layer surrounding a baculovirus occlusion body. Virology 163, 33-42.

Wigglesworth (1930). The formation of peritrophic membranes in insects, with special reference to the larvae of mosquitoes. Q. J. Microsc. Sci. 73:593-616

Willink, E., M. A. Costilla. y. V. M. Osores (1990). Principales plagas del maíz: Daños, pérdidas y recomendaciones para la siembra. Avance Agroindustrial Alo II (42):1719

Willink, E. V. M. Osores y. M. A. Costilla (1993). Daños, pérdidas y niveles de daño económico por Spodoptera frugiperda (Lepidoptera: Noctuidae) en maíz. Rev Ind y Agric de Tucumán 70(1-2): 49-52

Xu, H. J., Yang, Z. N., Zhao, J. F., Tian, C. H., Ge, J. Q., Tang, X. D., Bao, Y. Y. \& Zhang, C. X. (2008a). Bombyx mori nucleopolyhedrovirus ORF56 encodes an occlusionderived virus protein and is not essential for budded virus production. J Gen Virol 89, 1212-1219.

Yang, S. \& Miller, L. K. (1998). Expression and mutational analysis of the baculovirus very late factor 1 (vlf-1) gene. Virology 245, 99-109. 
Yin, F., Wang, M., Tan, Y., Deng, F., Vlak, J. M., Hu, Z. \& Wang, H. (2008). A functional F analogue of Autographa californica nucleopolyhedrovirus GP64 from the Agrotis segetum granulovirus. J Virol 82, 8922-8926.

Zimmermann (1975). Investigations on the transport function and structure of peritrophic membranes of the blowfly Calliphora erythrocephala Mg. Comp. Biochem. Physiol. 51B:181-86 
Capítulo 2

Evaluación de los efectos de EpapGV como incrementador de virulencia de nucleopoliedrovirus 


\section{Indice temático}

Introducción

Materiales y métodos

Resultados y discusión

Ensayos de interacción

Detección de agentes virales

Efecto sobre membrana peritrófica 


\section{Introducción}

Existen seis categorías de relaciones biológicas interespecíficas: antagonismo, mutualismo, comensalismo, amensalismo, competencia y neutralismo. Estas pueden ser aplicadas a la interacción entre virus, y entre los mismos y las células susceptibles de los insectos (Begon et al., 1996). Aquí nos referiremos sólo a tres de ellas: antagonismo, neutralismo y mutualismo. El antagonismo implica que una especie se beneficie a expensas de otra, esto caracteriza por ejemplo, a la depredación y el parasitismo en los organismos celulares, mientras que en los virus, el antagonismo se refiere a la replicación de un virus que va en detrimento de la replicación de otro virus. En el neutralismo, dos especies interactúan sin causarse daño o beneficio. El neutralismo en las interacciones virales queda representado cuando dos especies de virus infectan a las células, sin interferir la infección de uno con la del otro. También se le llama neutralismo de proliferación independiente (Lowe \& Paschke, 1968). En las interacciones mutualistas, un virus se beneficia de la presencia de otro.

En el caso particular de los baculovirus, se sugiere que el neutralismo es probablemente el menos frecuente en la naturaleza, ya que todas las especies interactúan unas con otras en cierta forma. Es posible que la sensibilidad de los métodos de detección utilizados en el estudio de los procesos de interacción pueda afectar la interpretación del fenómeno (Cheng \& Lynn, 2009)

Como ejemplo de interacción entre dos virus se puede citar a los virus ThorSNPV y ThorMNPV que fueron originalmente aislados en la poblaciones naturales de las larvas de Thysanoplusia orichalcea en el Oeste de Java, Indonesia (Cheng \& Carner, 2000; Cheng et al., 2005a). Las muestras originales consistieron de una mayoría de virus de ThorSNPV y una mínima cantidad de ThorMNPV. La forma de los OBs de ThorSNPV es tetraédrica y la forma de los OBs de ThorMNPV es poliédrica (Cheng \& Carner, 2000; Cheng et al., 2005) por lo cual eran fácilmente diferenciables. La propagación inicial de ambos virus fue llevada a cabo en larvas de la oruga desfoliadora de la soja, Pseudoplusia includens. Pasajes sucesivos realizados a partir del inóculo original dieron como resultado una reducción progresiva de ThorSNPV y un aumento de la ThorMNPV (Cheng \& Carner, 2000; Cheng et al., 2005c). ThorSNPV y ThorMNPV fueron separados y purificados para 
realizar bioensayos sobre $P$. includens. Los dos virus replican en el tejido graso y en matriz traqueal de $P$. includens pero los dos tipos de OBs no se encontraron en las mismas células (Cheng et al., 2005). Por lo tanto, es muy probable, que la interacción entre ThorSNPV y ThorMNPV en larvas de $P$. includens sea del tipo neutralista (Cheng \& Lynn, 2009).

El mutualismo puede ser favorecido evolutivamente ya que ambas especies se benefician en la interacción. Como ejemplo, se puede mencionar baculovirus aislados de Choristoneura fumiferana que constituyen una mezcla de al menos dos tipos de Nucleopolyhedrovirus, el CfMNPV y CfDEFNPV (Arif \& Doerfler, 1984; Lauzon et al., 2005a). El CfDEFNPV es considerado defectuoso, ya que no puede infectar larvas de C. fumiferana vía per os debido a que no puede pasar al epitelio intestinal para luego entrar en el hemocele y replicar en otros tejidos, mientras que CfMNPV es infectivo vía per os en larvas de C. fumiferana (Lauzon et al., 2005a). En una infección con ambos virus, el CfDEFNPV es en estas condiciones capaz de replicar en hemocele y otros tejidos de C. fumiferana. Por lo tanto, la acción de CfDEFNPV se ve favorecida por la presencia del virus de CfMNPV, mediante un mecanismo poco conocido. Una vez que ambos virus están en el hemocele, CfDEFNPV de alguna manera facilita la infección de CfMNPV ya que este último en la progenie viral siempre predomina (Lauzon et al., 2005b).

Otro ejemplo de interacciones mutualistas existe en ciertas poblaciones naturales de Spodoptera frugiperda Nucleopolyhedrovirus (SfMNPV) caracterizadas por presentar diferentes genotipos, algunos con deleciones de hasta $15 \mathrm{~kb}$ en comparación con el genoma completo de SfMNPV (Lopez-Ferber et al., 2003). Estos mutantes se encuentran con una frecuencia de alrededor del $35 \%$ en poblaciones naturales de SfMNPV y no son capaces de infectar a las larvas de $S$. frugiperda por vía oral debido a la ausencia de genes pifs (per os infectivity factors) que están localizados en la región eliminada en la deleción descripta (Kikhno et al., 2002; Lopez-Ferber et al., 2003). Se ha demostrado que existe una mayor patogenicidad en poblaciones naturales que contienen ambos genotipos que las poblaciones constituidas por virus que solo contienen el genoma completo, lo que sugiere una interacción de tipo mutualista entre estos genotipos virales (LopezFerber et al., 2003). En esta interacción, los genotipos sin los genes pif no producen infección per os, pero se benefician al ser co-ocluidos en los OBs de los virus con 
genotipo completo. Una vez que el virus delecionado se encuentra en el hemocele, probablemente replican más rápido que el genotipo completo debido a la corta longitud de su genoma (Barrett \& Dimmock, 1986; Lopez-Ferber et al., 2003).

En el caso de inoculaciones conjuntas entre baculovirus de distintos géneros, se demostró una asociación sinérgica entre un NPV (PuNPV) y un GV (PsunGV) cuando se co-inocularon larvas de Pseudaletia unipuncta (Tanada \& Hara, 1975; Tanada et al., 1973). Efectos similares fueron registrados para las combinaciones NPV-GV en larvas de Pseudaletia separata (PuNPV y PsunGV) (Hukuhara et al, 1987), Trichoplusia ni (TnGV y AcMNPV) (Derksen \& Granados, 1988), Xestia cnigrum (XcNPV y XcGV) (Goto, 1989) y Mamestra brassicae (MbNPV y XcGV) (Mukawa \& Goto, 2007). Al factor responsable de este aumento de la virulencia, se lo denominó factor acrecentador de virulencia (viral enhancing factor, enhancin o VEF) y se lo encontró en varios GVs y en algunos NPVs (Bischoff \& Slavicek, 1997; Peng et al., 1999; Slavicek \& Popham, 2005; Wang \& Granados, 1997b). Los VEF son una clase de metaloproteasas que facilitan la infección viral por degradación de proteínas de alto peso molecular presentes en la matriz de la membrana peritrófica (MP) del intestino medio del insecto (Derksen \& Granados, 1988; Slavicek \& Popham, 2005). Las proteínas de la MP, son el blanco de acción de los VEF (Wang \& Granados, 1997b). Sin embargo, la interacción puede resultar antagónica como se puede ejemplificar en una infección mixta con un NPV y un GV, descripta en larvas de Pseudaletia unipuncta (Tanada \& Watanabe, 1971). En la este caso, el GV ayuda a la infección del NPV pero la patogenicidad de la mezcla es menor que la del GV solo. Esto se debe a que en la coinfección, las proteínas VEF presentes en los gránulos del GV alteran la MP facilitando el pasaje de los ODVs del NPV hacia las células intestinales susceptibles pero cuando ambos virus están presentesen el hemocele, la replicación del NPV interfiere con la replicación del GV (Roelvink et al., 1995; Wang \& Granados, 1997a; Tanada \& Watanabe, 1971).

Debido al efecto que produce sobre la MP, el gen vef es de interés no solamente para el mejoramiento genético de los baculovirus sino también para la obtención de plantas transgénicas que mediante su expresión intentan desequilibrar la homeostasis intestinal de los insectos plaga de cultivos de interés económico (Cao et al., 2002; Liu et al., 2006).

Considerando que E. aporema y A. gemmatalis son especies que se presentan en 
ciertas áreas como plagas simultáneas (para las cuales se dispone de formulaciones baculovirales para ser evaluadas en el campo) y sobre la base de los antecedentes mencionados, se procedió al estudio de la posible interacción entre ambos virus, en larvas de $A$. gemmatalis y de E. aporema. En colaboración con otros miembros del grupo de trabajo, se evaluó el efecto de mezclas virales con los virus de EpapGV y AgMNPV en larvas de E. aporema y A. gemmatalis (Biedma, 2009). En este capítulo se detallan dichos estudios y se analizan las potenciales causas de la interacción, con el fin de avanzar en la identificación de genes de EpapGV con posible incidencia en el aumento de la virulencia natural de nucleopoliedrovirus. 


\section{Materiales y métodos}

Insectos. Las larvas de Epinotia aporema y Anticarsia gemmatalis, empleadas para la multiplicación de virus y los bioensayos, fueron provistas por el insectario del IMYZA-INTA, Castelar. La cría de los insectos se realizó bajo condiciones controladas de temperatura $\left(26 \pm 1^{\circ} \mathrm{C}\right)$, humedad relativa $(50-70 \%)$, fotoperíodo (14:10 L/O) y fue mantenida en dieta artificial (Greene et al., 1976).

Virus. Los virus EpapGV (aislamiento argentino) y AgMNPV (aislamiento brasileño 2D) fueron multiplicados en larvas de cuarto estadio de sus respectivos hospedantes. La propagación se realizó por contaminación superficial de la dieta (sin formaldehído) con cuerpos de oclusión $\left(1 \times 10^{3} \mathrm{OBs} / \mathrm{mm}^{2}\right)$. Las larvas fueron mantenidas bajo condiciones controladas de temperatura $\left(26 \pm 1^{\circ} \mathrm{C}\right)$ y humedad $(50 \%)$ hasta el momento de recolección del material infectado.

Bioensayos. Los ensayos in vivo fueron realizados según la metodología descripta por Hughes y Wood (1986). Para ello, larvas de A. gemmatalis fueron mantenidas en recipientes individuales, sin alimento, durante 12 hs. A continuación se les suministró una gota de la suspensión viral a evaluar dispuesta sobre Parafilm, utilizándose en la misma suspensión sacarosa al 1\% como fagoestimulante y Coomassie Brillant Blue al $0,1 \%$ como colorante para la verificación final de la ingesta. Para la realización del ensayo se tuvieron en cuenta los datos de volúmenes ingeridos por larvas de tercer estadio de $A$. gemmatalis (155 $\pm 13,9 \mathrm{nl})$ (Kunimi \& Fuxa, 1996), la $\mathrm{DL}_{50}$ de AgMNPV (168 OB/larva) y los antecedentes acerca de la ausencia de virulencia de EpapGV hacia $A$. gemmatalis (Sciocco-Cap et al., 2001)

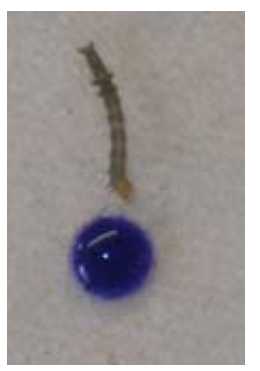

Fig. 2.1: Método utilizado para aplicación de virus: A las larvas de Anticarsia gemmatalis de tercer se les ofreció la suspensión coloreada como alimento y se seleccionaron aquellas que mostraron coloración hasta la mitad del tracto intestinal. 
Los ensayos se realizaron en una cámara climatizada a $26 \pm 1^{\circ} \mathrm{C}$ y $50 \%$ de humedad relativa. Se ensayaron dos dosis de AgMNPV (50 y 300 OB/larva) y una de EpapGV (6000 OB/larva) sobre 30 individuos por tratamiento, realizándose tres repeticiones. Se utilizaron como inóculo tanto los virus individuales (AgMNPV-2D y EpapGV) como la mezcla (AgMNPV/EpapGV en relación 50/6000 OB/larva y 300/6000 OB/larva, respectivamente) (Tabla 2.1).

Tabla 2.1. Tratamientos y dosis utilizadas sobre larvas del $3^{\mathrm{er}}$ estadio de Anticarsia gemmatalis.

\begin{tabular}{|c|c|}
\hline Tratamiento & Dosis \\
\hline $1 a$ & 50 OB de AgMNPV \\
\hline $1 b$ & 300 OB de AgMNPV \\
\hline $2 a$ & 50 OB de AgMNPV +6000 OB de EpapGV \\
\hline $2 b$ & 300 OB de AgMNPV + 6000 OB de EpapGV \\
\hline 3 & 6000 OB de EpapGV \\
\hline
\end{tabular}

Las larvas control fueron tratadas en forma idéntica con soluciones que no contenían virus. Una vez ingerida la dosis, las larvas fueron transferidas a recipientes individuales conteniendo dieta artificial. La mortalidad fue registrada a intervalos de $12 \mathrm{~h}$. El cálculo de los respectivos tiempos de supervivencia medios se realizó utilizando el programa Vistat ${ }^{\circledR}$ (Cornell University). Los resultados fueron analizados estadísticamente mediante el análisis de varianza (ANOVA) usando el software InfoStat (versión 2008). Para la comparación de los valores obtenidos $\left(T_{50}\right)$ se utilizó el test de Menor Diferencia Significativa (LSD) con un grado de significación $(\alpha)$ de 0,05.

Extracción de DNA total a partir de larvas utilizadas en bioensayos. Las larvas recolectadas fueron homogeneizadas en baño hielo-agua y la suspensión resultante se filtró a través de una gasa colocada en un tubo eppendorf de 0,5 ml perforado en su base. El filtrado fue tratado con $\mathrm{Na}_{2} \mathrm{CO}_{3}$ a concentración final de 0,1 $\mathrm{M}$ durante 30 min, se neutralizó la solución mediante agregado de Tris- $\mathrm{HCl}(\mathrm{pH} \mathrm{6,2)}$. Las muestras fueron hervidas por 5 min y se utilizó $1 \mu$ le esta solución para la reacción 
de PCR (Manzan et al., 2008).

PCR. La presencia de DNA viral de AgMNPV y EpapGV fue determinada mediante PCR utilizando primers específicos que amplifican el ORF de poliedrina (orf-I y orf-f) y el ORF de granulina (Gr-up y Gr-down), respectivamente (Arana et al., 2001; Parola et al., 2002). Como controles positivos se utilizaron DNAs de AgMNPV y de EpapGV. Los productos de amplificación fueron analizados en geles de agarosa al $1 \%$ y visualizados bajo luz UV mediante tinción con bromuro de etidio.

Preparación de cuerpos de oclusión y extracción de DNA. Las larvas infectadas obtenidas del bioensayo fueron maceradas en mortero agregando agua para favorecer la homogeneización, esta mezcla se incubó a temperatura ambiente durante una semana. Posteriormente, la suspensión se filtró a través de gasa y se agregó SDS a concentración final de 0,1\%. Se centrifugó 2 min a 2000 rpm en rotor SS34 (Sorvall) para eliminar todos los restos celulares. El sobrenadante se centrifugó a $7000 \mathrm{rpm}$ durante 20 minutos, a $4^{\circ} \mathrm{C}$. El pellet se resuspendió en agua y se centrifugó por 20 min a 5000 rpm; este paso se realizó tres veces a modo de lavado. Finalmente, se resuspendieron en agua y se verificó su limpieza por medio de observación al microscopio de contraste de fase (400X). A una suspensión de 1 $x 10^{9}$ OBs en $500 \mu \mathrm{l}$ de agua, se le agregó $55 \mu \mathrm{l}$ de $\mathrm{Na}_{2} \mathrm{CO}_{3} 1 \mathrm{M}$ y se incubó $30 \mathrm{~min}$ a temperatura ambiente para permitir la disolución de los OBs y la liberación de los viriones. Cuando la solución se tornó transparente se agregaron $55 \mu \mathrm{l}$ de Tris- $\mathrm{HCl} 1$ M pH 7,6 para neutralizar la suspensión. Se centrifugó a 7000 rpm durante 2 min para sedimentar los cuerpos de oclusión no disueltos. El sobrenadante se llevó a una concentración final de $10 \mathrm{mM}$ Tris- $\mathrm{HCl}(\mathrm{pH} 7,6), 10 \mathrm{mM}$ EDTA, 0,25\% SDS y $500 \mu \mathrm{g} / \mathrm{ml}$ proteinasa $\mathrm{K}$, se incubó durante 14 hs a $37^{\circ} \mathrm{C}$ con agitación suave. Se realizaron tres extracciones sucesivas (fenol/fenol-cloroformo-isoamílico/cloroformoisoamílico) agregando $500 \mu \mathrm{l}$ de solvente orgánico en cada caso. Se llevó la fase acuosa a una concentración final de $0,2 \mathrm{M} \mathrm{NaCl}$, se agregó $500 \mu \mathrm{l}$ de isopropanol para precipitar y posteriormente se lavó el pellet con $500 \mu \mathrm{l}$ de etanol $70 \%$ y se centrifugó a 14000 rpm 10 min. El pellet se resuspendió en $50 \mu \mathrm{l}$ de TE. 
Extracción de membranas peritróficas y SDS-PAGE. Larvas del $3^{\circ}$ estadio de $A$. gemmatalis fueron alimentadas con inóculos conteniendo las dosis ensayadas previamente (50 poliedros de AgMNPV, mezclas de 300 poliedros y 6000 gránulos, con 6000 gránulos de EpapGV) y únicamente con la solución fagoestimulante. Confirmada la ingesta, las larvas fueron depositadas en recipientes de forma individual y 12 horas post-infección diseccionadas para la extracción de sus membranas peritróficas. Las mismas fueron lavadas en agua destilada, eliminando el contenido intestinal y rápidamente homogeneizadas en buffer de corrida y sus proteínas separadas por electroforesis en gel de poliacrilamida al 10\% (SDS-PAGE) (Laemmli, 1970) usando el equipo Mini-protean II (Bio-Rad). Posteriormente el gel fue teñido con Coomasie Blue.

Búsqueda por PCR de vef (viral enhancing factor) en el genoma de EpapGV. El alineamiento de secuencias de vef encontradas en la base de datos de GenBank permitió la identificación de secuencias conservadas que fueron utilizadas para el diseño de los primers enh-fw 5' TTGTTTCGTTTCAGAGG 3' y enh-rev 5' TGTTCGGGTGTCATCG 3' (Ta $48.9^{\circ} \mathrm{C}$ ). El producto de amplificación (212 pb) fue analizado en geles de agarosa al $1 \%$ y visualizados bajo luz UV mediante tinción con bromuro de etidio. Como control positivo se utilizó DNA de Xestia c-nigrum GV (XcGV) el cual codifica en su genoma cuatro vefs. EI DNA fue enviado gentilmente por la Dra. Chie Goto (National Agricultural Research Center, Tsukuba, Japón) .

Microscopia electrónica de barrido de membranas peritróficas (MP). Para la realización de este estudio se siguió la metodología descripta por Mitsuhashi et al., (2007). Larvas de $3^{\circ}$ estadio de $A$. gemmatalis se alimentaron con inóculos conteniendo las dosis ensayadas previamente (50 poliedros de AgMNPV, mezclas de 300 poliedros y 6000 gránulos, con 6000 gránulos de EpapGV) y únicamente con la solución fagoestimulante. Confirmada la ingesta, las larvas fueron depositadas en recipientes de forma individual y a las 18 hs postratamiento, las larvas fueron utilizadas para la extracción de sus MP. Cada larva fue inmovilizada en hielo y posteriormente diseccionada para la extracción de la MP. Las mismas se lavaron en PBS $0,1 \%$ y se fijaron a temperatura ambiente en glutaraldehído al $1 \%$. Cada 
muestra se deshidrató en una serie de etanol (50,70, 90, y 100\%). Las muestras resultantes se deshidrataron mediante la realización de punto crítico (BAL-TEC, modelo CP-30) y metalizadas con oro (JEOL mod. Fine Coat lon Sputter). Posteriormente se examinaron de forma individual en microscopio de barrido (JEOL, modelo JSM-6360 LV). 


\section{Resultados y discusión}

\section{Ensayos de interacción}

Inicialmente, se realizó una primera evaluación sobre el efecto que produce el agregado de preparaciones de cuerpos de oclusión de EpapGV cuando es aplicado de forma conjunta con cuerpos de oclusión de AgMNPV, en larvas de Anticarsia gemmatalis.

En el siguiente gráfico se muestra el porcentaje de mortalidad acumulada de cada muestra ensayada (Fig. 2.2). Se comenzó registrar mortalidad a partir del cuarto día postratamiento.

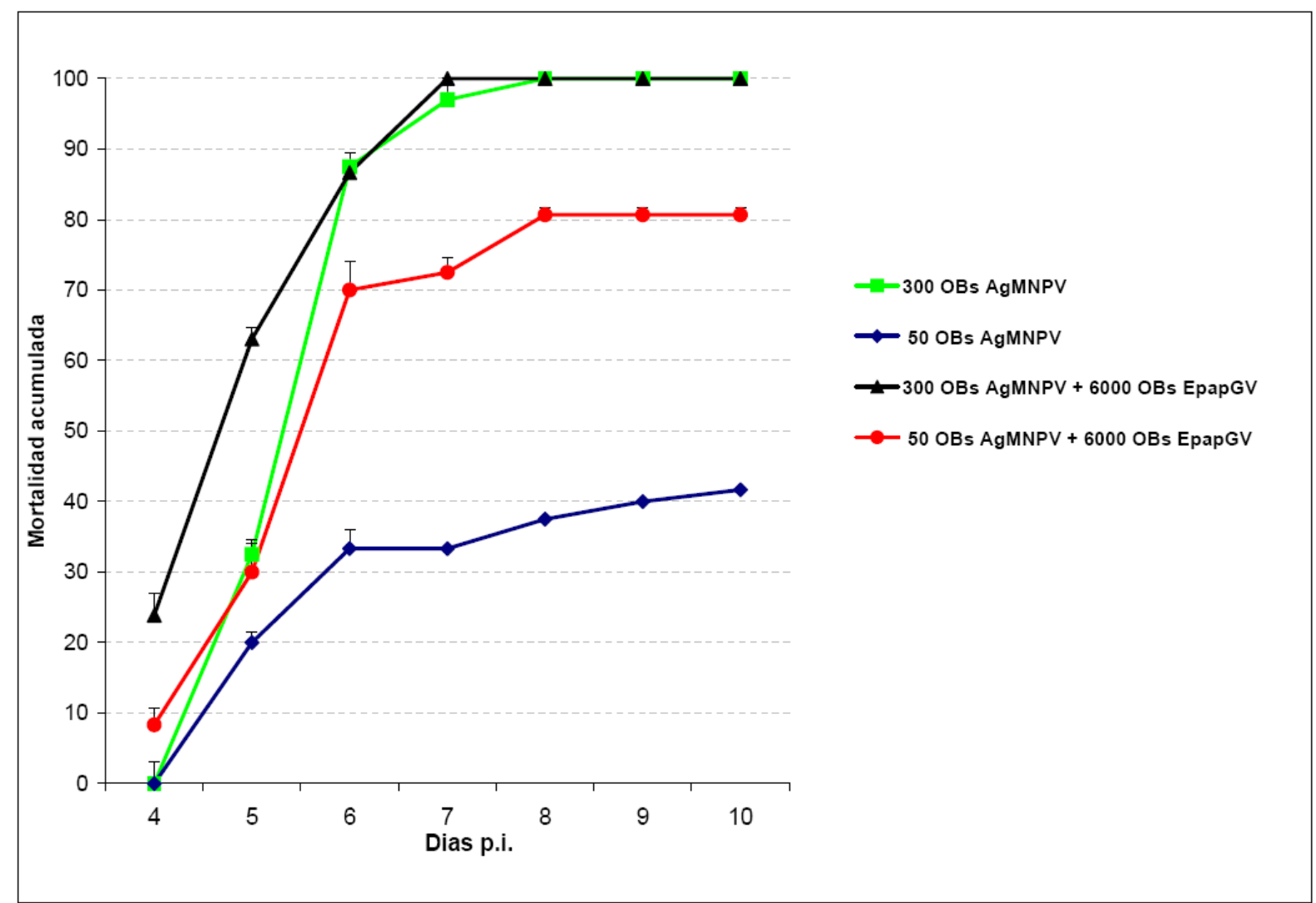

Fig. 2.2: Porcentaje de mortalidad acumulada vs. días post-infección (p.i.). Bioensayos realizados sobre larvas de $A$. gemmatalis de tercer estadio, tratadas con AgMNPV sólo (300 y 50 poliedros, OB por larva) o con la mezcla viral AgMNPV/EpapGV (300/6000 o 50/6000, poliedros/gránulos, OBs por larva). No se observó mortalidad en los controles, ni en el tratamiento con EpapGV solo. Las desviaciones estándar oscilaron entre $\pm 2,33$ hs (50 OBs AgMNPV) y $\pm 10,61$ hs (300/6000 mezcla viral). 
Con los datos de mortalidad obtenidos, para cada uno de los tratamientos y dosis ensayadas, se calculó el Tiempo Letal Medio $\left(\mathrm{TL}_{50}\right)$. Posteriormente se realizó un análisis de varianza, obteniéndose los resultados que se presentan en la Tabla 2.2. Como puede observarse en la misma, el menor $\mathrm{TL}_{50}$ se registró con la mayor dosis de AgMNPV en combinación con EpapGV (Tratamiento $2 b$ ). Entre los tratamientos $1 b$ y $2 a$ no se observaron diferencias significativas, a pesar de que se utilizó en el tratamiento $1 \mathrm{~b}$ una dosis de AgMNPV seis veces menor que en $2 \mathrm{a}$.

Tabla 2.2: Valores estimados de Tiempo Letal Medio $\left(T L_{50}\right)$ y análisis de la varianza de los distintos tratamientos y dosis utilizados en los bioensayos

\begin{tabular}{|c|c|c|c|}
\hline Tratamiento & AgMNPV (OBs) & EpapGV (OBs) & $\mathrm{TL}_{50}$ en días $\left.{ }^{* *}\right)$ \\
\hline $1 \mathrm{a}$ & 50 & & $7.7^{\mathrm{c}}$ \\
\hline $1 \mathrm{~b}$ & 50 & 6000 & $5.7^{\mathrm{b}}$ \\
\hline $2 \mathrm{a}$ & 300 & & $5.6^{\mathrm{b}}$ \\
\hline $2 \mathrm{~b}$ & 300 & 6000 & $5.1^{\mathrm{a}}$ \\
\hline
\end{tabular}

$\left.{ }^{* *}\right)$ Las letras diferentes indican diferencias significativas en los valores de $\mathrm{TL}_{50}$ $(p<0.05)$.

De estos datos se desprenden dos resultados a destacar: el primero muestra que el agregado de gránulos de EpapGV permitiría utilizar una menor dosis de AgMNPV para obtener un mismo $\mathrm{TL}_{50}$; el segundo comprueba la existencia de una interacción positiva entre las preparaciones de AgMNPV y EpapGV, que favorece el uso de la mezcla viral en comparación con el uso del virus de AgMNPV solo.

Los lepidópteros plaga E. aporema y A. gemmatalis pueden detectarse sobre el mismo cultivo en la misma época del año. De cada uno de estos organismos se aislaron baculovirus capaces de controlar de manera eficiente a su hospedador, evitando los daños que ocasionan sobre los cultivos. En este trabajo se realizaron estudios tendientes a evaluar la interacción entre estos diferentes virus y el efecto de ambos aplicados conjuntamente. El efecto del uso de las mezclas virales es más notorio en larvas de $A$. gemmatalis inoculadas con 50 OB de AgMNPV mezclados con 6000 OB de EpapGV, tratamiento con el que se obtuvo tanto una disminución 
significativa del $\mathrm{TL}_{50}$ como un efecto sinérgico (mayor mortalidad larval) a igual dosis de AgMNPV.

Si bien tanto en los tratamientos de 300 OB y $300 / 6000$ OB se alcanzó el $100 \%$ de mortalidad de las larvas tratadas, las sometidas a la segunda dosis presentaron un $\mathrm{TL}_{50}$ significativamente menor. Por los resultados obtenidos se puede aseverar que el agregado de gránulos de EpapGV en combinación con AgMNPV incrementa la eficacia insecticida de este último sobre su propio hospedador.

\section{Detección de agentes virales}

Para verificar si esta disminución observada fue consecuencia de una coinfección viral, se realizó una PCR sobre el DNA total obtenido del conjunto larvas muertas de A. gemmatalis con síntomas de infección. Para identificar a los virus se realizaron reacciones de PCR individuales sobre el DNA extraído. En la detección de EpapGV se utilizó un juego de primers que amplifican el gen de granulina del mismo, dando un producto de $830 \mathrm{pb}$; mientras que para identificar la presencia de AgMNPV se utilizó un juego de primers dirigidos al gen de poliedrina, dando un producto de 750 $\mathrm{pb}$.

Como se observa en la Fig. 2.3, en larvas muertas de $A$. gemmatalis y con la utilización de los primers para amplificar el gen de poliedrina (gel B) solo se detectó la presencia del AgMNPV cuando este agente fue utilizado sólo ( $\mathrm{Gel} \mathrm{B}$, calle 3) o en combinación con EpapGV (Gel B, calle 4). Utilizando el DNA extraído de las mismas larvas y utilizando primers para amplificar el ORF de granulina, la PCR resultó negativa. Estos datos indicarían que el agente causal de la mortalidad de las larvas de A. gemmatalis, fue en todos los casos, el virus homónimo. 

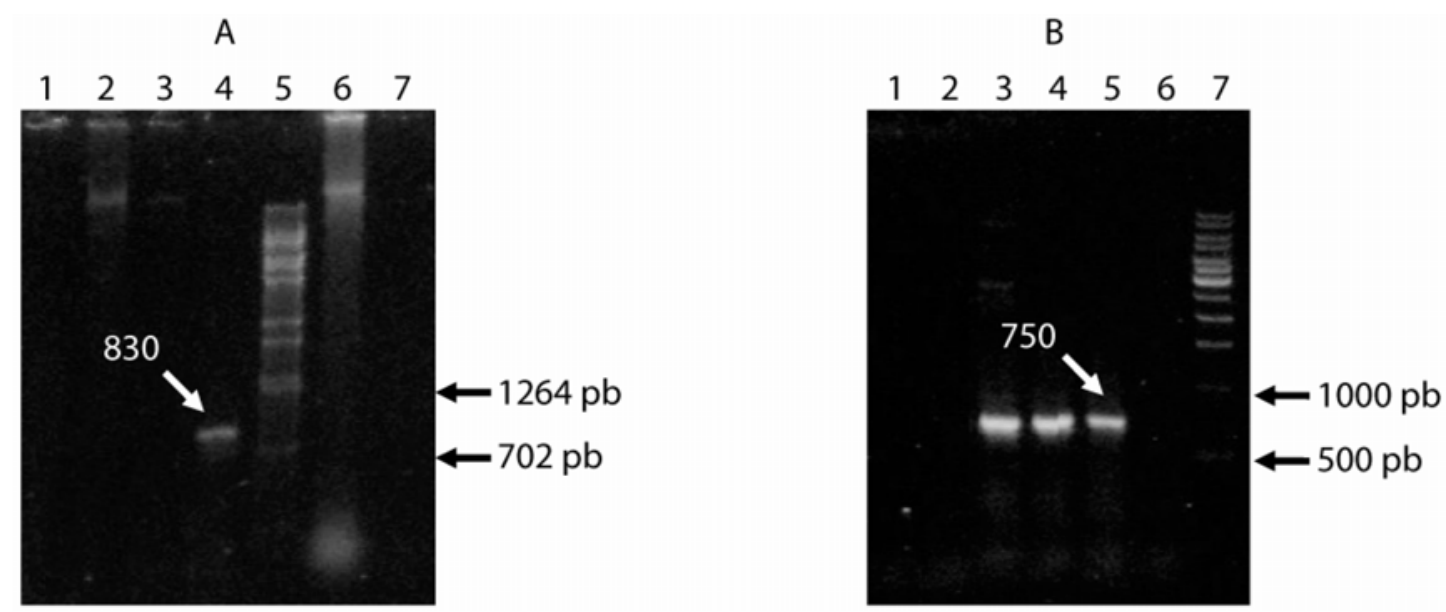

Fig. 2.3: Productos de PCR obtenidos utilizando primers específicos que amplifican granulina (gel A) y poliedrina (gel B). En A: Calles 1-3, DNA de larvas tratadas con: 1: AgMNPV, 2: AgMNPV/EpapGV, 3: EpapGV; 4: DNA EpapGV (control positivo), 5: DNA/BstEIl, 6: DNA de larvas sin tratar (control negativo), 7: DNA de AgMNPV (control negativo). En B: Calle 1: DNA EpapGV (control negativo); calles 2-4, DNA de larvas tratadas con: 2: EpapGV, 3: AgMNPV, 4: AgMNPV/EpapGV; 5: DNA de AgMNPV (control positivo), 6: Control larvas (control negativo), 7: 500 pb. Las flechas blancas señalan la banda de interés; a la izquierda del gel se indican los tamaños de algunas de las bandas del marcador de PM.

En coinfecciones con baculovirus con alta a moderada homología, se describieron eventos de recombinación tanto en cultivo de células (Croizier \& Ribeiro, 1992; Hajos et al., 2000), (Kondo \& Maeda, 1991) como en larvas de insecto (Kamita et al., 2003; Merryweather-Clarke et al., 1994). Por tal motivo, para confirmar los datos obtenidos por PCR se procedió a verificar la identidad del virus obtenido a partir de las larvas muertas sometidas a las mezclas virales (tratamientos $1 \mathrm{~b}$ y $2 \mathrm{~b}$ ). Para tal fin, se realizó una extracción de DNA a partir de los OBs obtenidos de las larvas y se lo digirió con enzimas de restricción. Como se observa en la Figura 2.4 el perfil restricción obtenido para el DNA extraído de los cuerpos de oclusión de las larvas muertas, corresponde al de AgMNPV. 


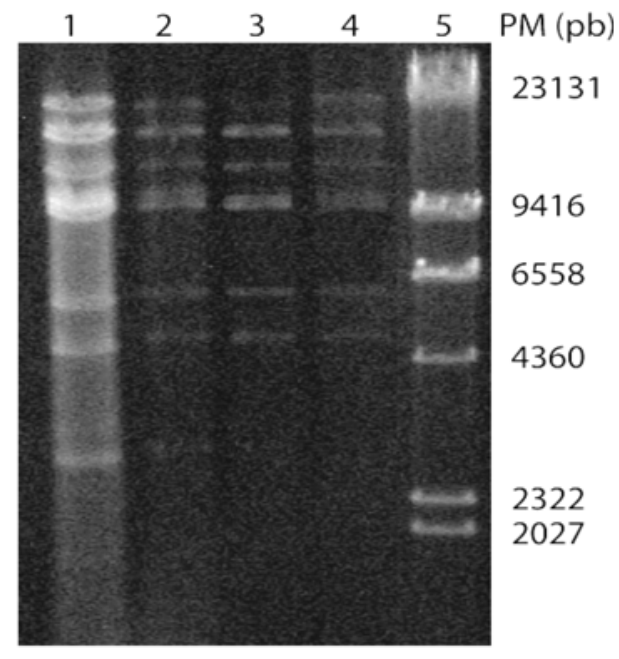

Fig. 2.4: Patrón de restricción de DNA obtenido a partir de OBs extraídos de larvas de $A$. gemmatalis sometidas a distintos tratamientos. DNA extraído de OBs presentes en: Calle 1: control AgMNPV extraído de cultivo celular. Calle 2: larvas infectadas con la mezcla 50 OBs AgMNPV/6000 OBs EpapGV. Calle 3: larvas infectadas con la mezcla 300 OBs AgMNPV/6000 OBs EpapGV .Calle 4: larvas infectadas con AgMNPV sólo. Calle 5: marcador de peso molecular ( $\lambda /$ HindIII).

Entre la búsqueda de las causas del efecto observado se evaluó la hipótesis de una infección cruzada. Los resultados negativos de detección mediante PCR del genoma viral de EpapGV en larvas de A. gemmatalis y de AgMNPV en larvas de $E$. aporema mostraron la falta de infectividad en el huésped evaluado. Esto confirmó los resultados obtenidos previamente respecto al rango de hospedantes de EpapGV (Sciocco-Cap et al., 2001). Por consiguiente, se puede inferir que el aumento de la virulencia a partir de la mezcla viral sobre larvas de A. gemmatalis, estaría asociada a la adición de preparaciones de cuerpos de oclusión de EpapGV y no a una coinfección.

\section{Efecto sobre la membrana peritrófica y SDS-PAGE}

Como se mencionó anteriormente, existen factores codificados en el genoma de ciertos GVs que poseen la capacidad de incrementar la infectividad de NPVs (Derksen \& Granados, 1988; Lara-Reyna et al., 2003; Lepore et al., 1996; Peng et al., 1999; Rao et al., 2004). Los más estudiados actúan sobre la membrana peritrófica (MP) del hospedador, la cual posee entre sus funciones impedir el pasaje de agentes potencialmente dañinos. Esta membrana, compuesta principalmente por quitina y proteínas, es alterada en su estructura por componentes presentes o asociados al cuerpo de oclusión viral (Derksen \& Granados, 1988). La consecuencia de este daño, deriva en un mayor pasaje de los viriones a través de la MP facilitando el contacto entre el virión y el epitelio intestinal. Con el fin de verificar si algún factor proteico presente en el cuerpo de 
oclusión de EpapGV fue el agente causal de la disminución del $\mathrm{TL}_{50}$ observado en los ensayos previos, se realizó un patrón proteico de membranas peritróficas extraídas de las larvas sometidas a los distintos tratamientos evaluados (Fig. 2.5).

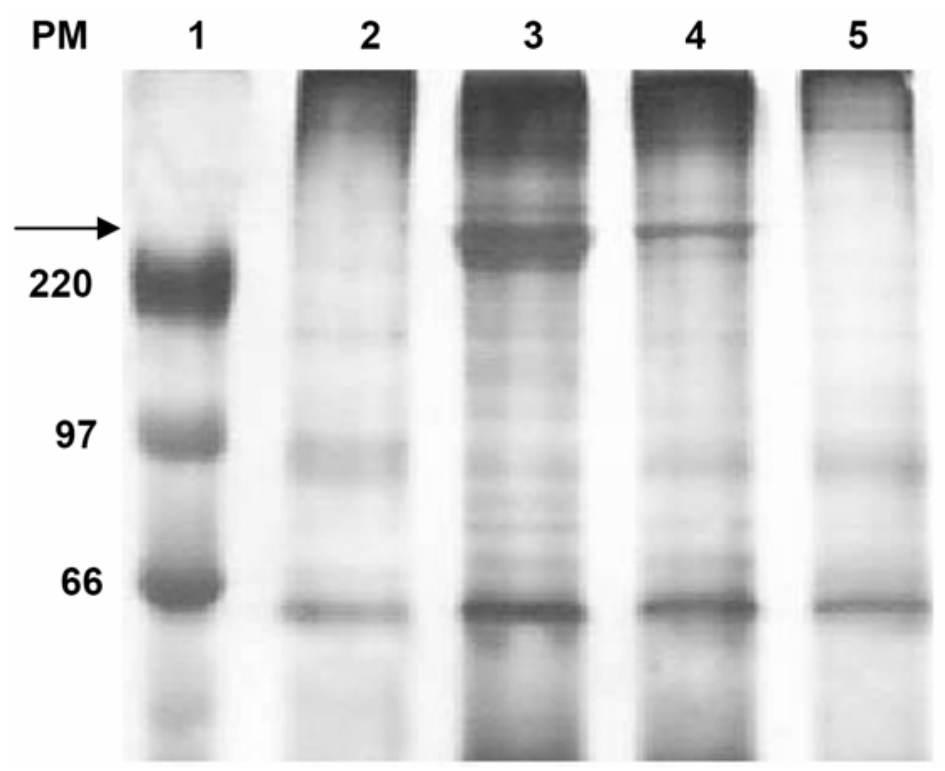

Fig. 2.5: SDS-PAGE de proteínas de membranas peritróficas extraídas de A. gemmatalis a los 90 minutos post-infección. Calle 1: Marcador de PM $(\mathrm{kDa})$. Calle2: Control (larvas sin infectar), calle 3: tratadas con AgMNPV + EpapGV (50/6000 OB/larva), calle 4: con EpapGV (6000 OB/larva), calle 5: con AgMNPV (50 OB/larva). Tinción con plata. La flecha productos de degradación de las proteínas de muy alto peso molécula.

Según los resultados obtenidos, se produciría una degradación de las proteínas de alto peso molecular en las membranas peritróficas de las larvas de $A$. gemmatalis sometidas al tratamiento con ambos virus (calle 3 ) y en las tratadas con EpapGV solo (calle 4); mientras que en las muestras correspondientes al tratamiento con AgMNPV (calle 5) como en el control (calle 2) las proteínas de alto peso molecular (cercanas al punto de siembra de la muestra) no fueron degradadas a productos de menor tamaño. Con el fin de confirmar esta hipótesis, se llevaron a cabo experimentos complementarios. 


\section{Búsqueda por PCR de vef (viral enhancing factor) en el genoma de EpapGV.}

En primer término, se procedió determinar la posible presencia del gen vef en el genoma de EpapGV. Con este fin, se realizaron alineamientos de las secuencias disponibles en las bases de datos y se diseñaron primers específicos para la búsqueda del ORF mediante amplificación genómica. Como control positivo se usó el DNA de Xestia c-nigrum Granulovirus (XcGV), que posee cuatro vefs en su genoma.

Se obtuvieron fragmentos del tamaño esperado (214 pb) para XcGV (control positivo), resultando negativa la amplificación sobre el DNA de EpapGV (Fig.3.4).

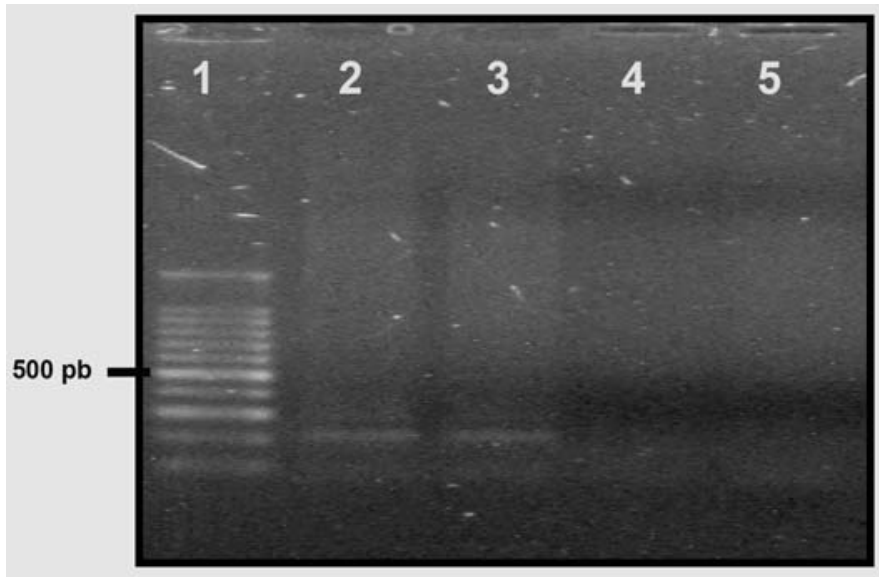

Fig. 3.4. PCR para la detección de un enhancin en el genoma de EpapGV. De izquierda a derecha. Calle 1: Marcador de peso molecular (100 pb). Calle 2: Control positivo, DNA de XcGV (dilución 1:10). Calle 3: Control positivo, DNA de XcGV (dilución 1:50). Calle 4: DNA de EpapGV. Calle 5: Control negativo

Estos resultados fueron luego confirmados al obtener la secuencia completa del genoma de EpapGV (Ferrelli, 2010).

\section{Microscopía electrónica de barrido de membranas peritróficas.}

Con el fin de complementar el análisis sobre el efecto de preparaciones de OBs de EpapGV en las membranas peritróficas de larvas de $A$. gemmatalis, se procedió a la observación de las mismas, bajo microscopio electrónico de barrido (Fig.2.6).

Los resultados muestran un deterioro en la estructura de la membrana peritrófica de larvas de A. gemmatalis tratadas con preparaciones de cuerpos de oclusión de EpapGV y, además, perforaciones asociadas a cuerpos cuerpos esferoidales de tamaño variable y con un diámetro promedio aproximado de aproximadamente 1 $\mu \mathrm{m}$. Su presencia indica que los mismos no fueron degradados tempranamente en 
el medio alcalino del intestino medio del hospedador, tal como ocurrió con los cuerpos de oclusión que encierran viriones en una matriz de poliedrina o de granulina. Este resultado fue luego confirmado mediante la observación de preparaciones de OBs tratadas con solución de $\mathrm{CO}_{3} \mathrm{Na}_{2}$ (ver Capítulo 3)
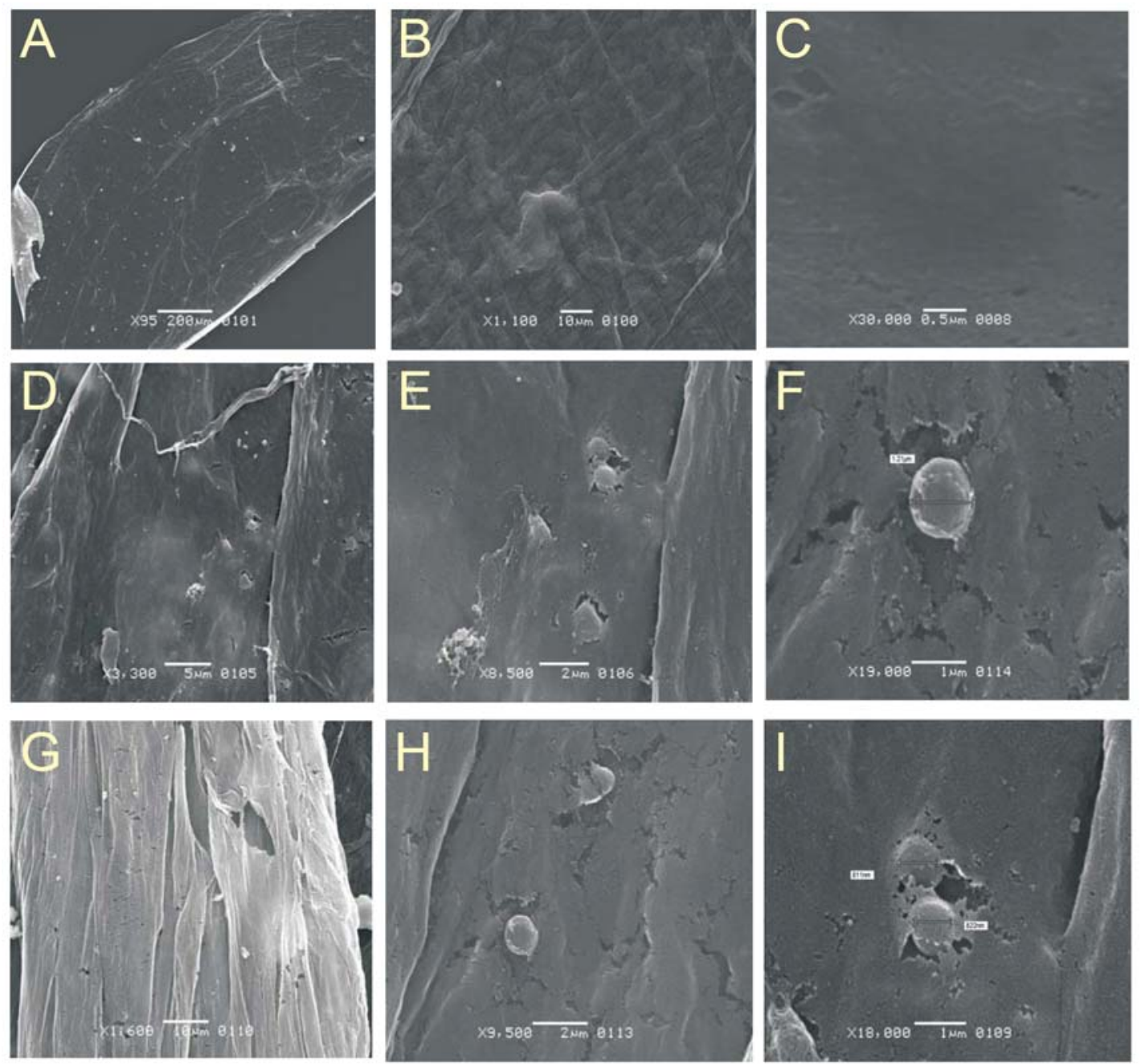

Fig. 2.6. Microscopía electrónica de barrido de membranas peritróficas de larvas del tercer estadio de Anticarsia gemmatalis infectadas solo con poliedros (A-C); mezcla de poliedros y gránulos (D- F) y solo con gránulos (G-I)

En estudios realizados previamente por nuestro grupo de trabajo, se observó la presencia de cuerpos electrodensos de mayor tamaño que los gránulos de EpapGV, tanto en cortes ultrafinos de tejidos infectados, como en preparaciones purificadas de OBs. Los mismos no contenían viriones y se asumió entonces que se trataba de cristales de granulina, tal como fuera sugerido por Hess y Falcon 
(1987) en estudios realizados sobre la patología producida por CpGV en larvas de Cydia pomonella (Goldberg, 2003) (Fig.2.7)

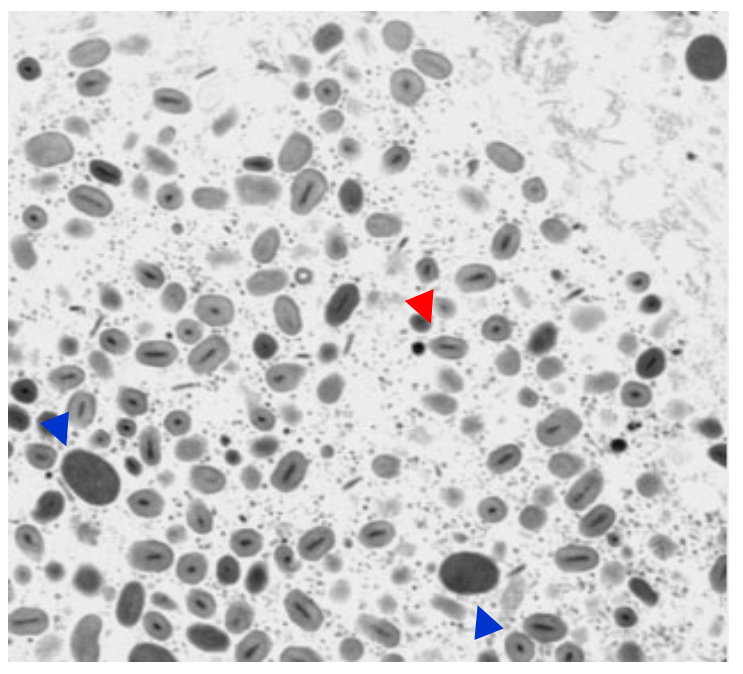

Fig. 2.7. Micrografía electrónica: con flechas rojas se indican los cuerpos de oclusión, que poseen una longitud promedio de $600 \mu \mathrm{m}$; con flechas azules se muestran cuerpos proteicos de aproximadamente 1 1,5 $\mu \mathrm{m}$ de largo (Foto: A. V. Goldberg).

El tamaño y la forma de estas estructuras son coincidentes con las observadas mediante microscopía de barrido, sobre las membranas peritróficas (MP) de las larvas tratadas con EpapGV.

Los resultados de todos los ensayos realizados estarían indicando la presencia de factores en los OBs o asociados a los mismos, capaces de actuar sobre la MP o sus componentes. Habiéndose confirmado la ausencia de genes vef, se realizó un análisis de las secuencias parciales disponibles del genoma de EpapGV (Parola, 2004), con el fin de ubicar otros genes descriptos en la literatura como posibles factores de incremento de virulencia. Se ubicó así un gen de interés a ser caracterizado y evaluado: gp37.

En relación a proteínas homólogas a GP37, cabe mencionar que en CfDEFMNPV (Gross et al., 1993; Liu \& Carstens, 1996) y en entomopoxvirus (otro grupo de virus entomopatógenos) (Dall et al., 1993; Gauthier et al., 1995; Mitsuhashi et al., 1998; Mitsuhashi \& Sato, 2000) se observó que pueden formar cristales, aunque hasta el presente no se ha descripto este tipo de inclusiones en el género Betabaculovirus. 


\section{Referencias}

Arif, B. M. \& Doerfler, W. (1984). Identification and localization of reiterated sequences in the Choristoneura fumiferana MNPV genome. EMBO J 3, 525-529.

Barrett, A. D. \& Dimmock, N. J. (1986). Defective interfering viruses and infections of animals. Curr Top Microbiol Immunol 128, 55-84.

Begon, M., Harper, J. L. \& Townsend, C. R. (1996). Ecology: individuals, populations, and communities. Oxford Press; Cambridge, Mass.: Blackwell Science.

Biedma, M. E. (2009). Desarrollo de un sistema de recombinación para su aplicación al estudio de determinantes genéticos que afectan la infectividad de baculovirus de interés agronómico. Tesis Doctoral; Universidad Nacional de La Plata.

Bischoff, D. S. \& Slavicek, J. M. (1997). Molecular analysis of an enhancin gene in the Lymantria dispar nuclear polyhedrosis virus. J Virol 71, 8133-8140.

Cao, J., Ibrahim, H., Garcia, J. J., Mason, H., Granados, R. R., and Earle, E. D. (2002). Transgenic tobacco plants carrying a baculovirus enhancin gene slows the development and increase the mortality of Trichoplusia ni larvae. . Plant Cell Rep $21: 244-250$

Croizier, G. R. \& Ribeiro, H. C. T. (1992). Recombination as a possible major cause of genetic heterogeneity in Anticarsia gemmatalis nuclear polyhedrosis virus wild populations. Virus Research 26, 183-196

Cheng, X. W., Carner, G. R., Lange, M., Jehle, J. A. \& Arif, B. M. (2005a). Biological and molecular characterization of a multicapsid nucleopolyhedrovirus from Thysanoplusia orichalcea (L.) (Lepidoptera: Noctuidae). J Invertebr Pathol 88, 126135.

Cheng, X. W., Carner, G. R., Lange, M., Jehle, J. A. \& Arif, B. M. (2005b). Biological and molecular characterization of a multicapsid nucleopolyhedrovirus from Thysanoplusia orichalcea (L.) (Lepidoptera: Noctuidae). J Invertebr Pathol 88, 126135. 
Dall, D., Sriskantha, A., Vera, A., Lai-Fook, J. \& Symonds, T. (1993). A gene encoding a highly expressed spindle body protein of Heliothis armigera entomopoxvirus. J Gen Virol 74 ( Pt 9), 1811-1818.

Derksen, A. C. \& Granados, R. R. (1988). Alteration of a lepidopteran peritrophic membrane by baculoviruses and enhancement of viral infectivity. Virology 167 , 242-250.

Gauthier, L., Cousserans, F., Veyrunes, J. C. \& Bergoin, M. (1995). The Melolontha melolontha entomopoxvirus (MmEPV) fusolin is related to the fusolins of lepidopteran EPVs and to the 37K baculovirus glycoprotein. Virology 208, 427-436.

Goto, C. (1989). Enhancement of a nuclear polyhedrosis virus (NPV) infection by a granulosis virus (GV) isolated from the spotted cutworm, Xestia c-nigrum L. (Lepidoptera:Noctuidae). Appl Entomol Zool 25, 135-137

Greene, G. L., Leppla, N. C. \& Dickerson, W. A. (1976). Velvetbean caterpillar: a rearing procedure and artificial medium. J Econ Entomol 69, 487-488.

Gross, C. H., Wolgamot, G. M., Russell, R. L., Pearson, M. N. \& Rohrmann, G. F. (1993). A 37-kilodalton glycoprotein from a baculovirus of Orgyia pseudotsugata is localized to cytoplasmic inclusion bodies. J Virol 67, 469-475.

Hajos, J. P., Pijnenburg, J., Usmany, M., Zuidema, D., Zavodszky, P. \& Vlak, J. M. (2000). High frequency recombination between homologous baculoviruses in cell culture. Arch Virol 145, 159-164.

Hukuhara, T., K. Tamura, Y. Zhu, H. Abe and Y. Tanada (1987). Synergistic factor shows specificity in enhancing nuclear polyhedrosis virus infections. Appl Entomol Zool 22, 235-236.

Kamita, S. G., Maeda, S. \& Hammock, B. D. (2003). High-frequency homologous recombination between baculoviruses involves DNA replication. J Virol 77, 1305313061. 
Kondo, A. \& Maeda, S. (1991). Host range expansion by recombination of the baculoviruses Bombyx mori nuclear polyhedrosis virus and Autographa californica nuclear polyhedrosis virus. J Virol 65, 3625-3632.

Kunimi, Y. \& Fuxa, J. R. (1996). Volumes ingested by four species of noctuids with reference to peroral droplet bioassay of baculoviruses. J Invertebr Pathol 68, 310311.

Laemmli, U. K. (1970). Cleavage of structural proteins during the assembly of the head of bacteriophage T4. Nature 227, 680-685.

Lara-Reyna, J., Del Rincon-Castro, M. C. \& Ibarra, J. E. (2003). Synergism between the nucleopolyhedroviruses of Autographa californica and Trichoplusia ni. Acta Virol 47, 189-194.

Lauzon, H. A., Jamieson, P. B., Krell, P. J. \& Arif, B. M. (2005). Gene organization and sequencing of the Choristoneura fumiferana defective nucleopolyhedrovirus genome. J Gen Virol 86, 945-961.

Lepore, L. S., Roelvink, P. R. \& Granados, R. R. (1996). Enhancin, the granulosis virus protein that facilitates nucleopolyhedrovirus (NPV) infections, is a metalloprotease. J Invertebr Pathol 68, 131-140.

Liu, J. J. \& Carstens, E. B. (1996). Identification, molecular cloning, and transcription analysis of the Choristoneura fumiferana nuclear polyhedrosis virus spindle-like protein gene. Virology 223, 396-400.

Liu, S., Li, H., Sivakumar, S. \& Bonning, B. C. (2006). Virus-derived genes for insectresistant transgenic plants. Adv Virus Res 68, 427-457.

Lopez-Ferber, M., Simon, O., Williams, T. \& Caballero, P. (2003). Defective or effective? Mutualistic interactions between virus genotypes. Proc Biol Sci 270, 2249-2255.

Lowe, R. E. \& Paschke, J. D. (1968). Pathology of a double viral infection of Trichoplusia ni. J Invertebr Pathol 12, 438-443. 
Manzán, M. A. (2002). Clonado molecular del genoma del virus de la granulosis de Epinotia aporema, EpapGV y caracterización del gen de la ecdisona glicosiltransferasa.Tesis Doctoral, Facultad de Ciencias Exactas, p. 156

Manzan, M. A., Aljinovic, E. M., Biedma, M. E., Sciocco-Cap, A., Ghiringhelli, P. D. \& Romanowski, V. (2008). Multiplex PCR and quality control of Epinotia aporema granulovirus production. Virus Genes 37, 203-211.

Merryweather-Clarke, A. T., Hirst, M. \& Possee, R. D. (1994). Recombination between genetically modified and unmodified Autographa californica nuclear polyhedrosis virus in Trichoplusia ni larvae. Acta Virol 38, 311-315.

Mitsuhashi, W., Furuta, Y. \& Sato, M. (1998). The spindles of an entomopoxvirus of coleoptera (Anomala cuprea) strongly enhance the infectivity of a nucleopolyhedrovirus in lepidoptera. J Invertebr Pathol 71, 186-188.

Mitsuhashi, W., Kawakita, H., Murakami, R., Takemoto, Y., Saiki, T., Miyamoto, K. \& Wada, S. (2007). Spindles of an entomopoxvirus facilitate its infection of the host insect by disrupting the peritrophic membrane. J Virol 81, 4235-4243.

Mitsuhashi, W. \& Sato, M. (2000). Enhanced Infection of a Nucleopolyhedrovirus in a Lepidopteran Pest (Spilosoma imparilis) by Spindles of a Coleopteran Entomopoxvirus (EPV) (Anomala cuprea EPV). Japanese Forestry Society

Mukawa, S. \& Goto, C. (2007). Enhancement of nucleopolyhedrovirus infectivity against Mamestra brassicae (Lepidoptera: Noctuidae) by proteins derived from granulovirus and a fluorescent brightener. J Econ Entomol 100, 1075-1083.

Parola, A. D. (2004). Caracterización molecular de un virus de la granulosis de Epinotia aporema. Tesis Doctoral; Universidad Nacional de La Plata.

Peng, J., Zhong, J. \& R, R. G. (1999). A baculovirus enhancin alters the permeability of a mucosal midgut peritrophic matrix from lepidopteran larvae. J Insect Physiol 45, 159-166.

Rao, R., Fiandra, L., Giordana, B., de Eguileor, M., Congiu, T., Burlini, N., Arciello, S., Corrado, G. \& Pennacchio, F. (2004). AcMNPV ChiA protein disrupts the 
peritrophic membrane and alters midgut physiology of Bombyx mori larvae. Insect Biochem Mol Biol 34, 1205-1213.

Roelvink, P. W., Corsaro, B. G. \& Granados, R. R. (1995). Characterization of the Helicoverpa armigera and Pseudaletia unipuncta granulovirus enhancin genes. $J$ Gen Virol 76, 2693-2705.

Sciocco-Cap, A., Parola, A. D., Goldberg, A. V., Ghiringhelli, P. D. \& Romanowski, V. (2001). Characterization of a granulovirus isolated from Epinotia aporema Wals. (Lepidoptera: Tortricidae) larvae. Appl Environ Microbiol 67, 3702-3706.

Slavicek, J. M. \& Popham, H. J. (2005). The Lymantria dispar nucleopolyhedrovirus enhancins are components of occlusion-derived virus. J Virol 79, 10578-10588.

Tanada, Y. \& Hara, S. (1975). Enzyme synergistic for insect viruses. Nature 254, 328-329.

Tanada, Y., Himeno, M. \& Omi, E. M. (1973). Isolation of a factor, from the capsule of a granulosis virus, synergistic for a nuclear-polyhedrosis virus of the armyworm. $J$ Invertebr Pathol 21, 31-40.

Tanada, Y. \& Watanabe, H. (1971). Disc electrophoretic and serological studies of the capsule proteins obtained from two strains of a granulosis virus of the armyworm, Pseudaletia unipuncta. J Invertebr Pathol 18, 307-312.

Wang, P. \& Granados, R. R. (1997a). An intestinal mucin is the target substrate for a baculovirus enhancin. Proc Natl Acad Sci U S A 94, 6977-6982. 


\section{Capítulo 3}

Estudio y caracterización de un homólogo a gp37 encontrado en el genoma de EpapGV 


\section{Indice temático}

$\begin{array}{ll}\text { Introducción } & 61\end{array}$

$\begin{array}{ll}\text { Materiales y métodos } & 65\end{array}$

$\begin{array}{ll}\text { Resultados y discusión } & 72\end{array}$

$\begin{array}{ll}\text { Sequenciación y caracterización de gp37 de EpapGV } & 72\end{array}$

$\begin{array}{ll}\text { Análisis filogenético de GP37 y homólogos } & 76\end{array}$

$\begin{array}{ll}\text { Expresión de GP37 en un sistema eucariota } & 78\end{array}$

Determinación de la presencia de GP37 en OB de EpapGV 80

$\begin{array}{ll}\text { Referencias } & 83\end{array}$

Este capítulo forma parte de la siguiente publicación

Analysis of EpapGV gp37 gene reveals a close relationship between granulovirus and entomopoxvirus. Salvador R, Ferrelli ML, Berretta MF, Mitsuhashi W, Biedma ME, Romanowski V, Sciocco-Cap A.

Virus Genes. 2012 Dec;45(3):610-3. doi: 10.1007/s11262-012-0800-3. Epub 2012 Aug 17. 


\section{Introducción}

Los estudios realizados sobre diferentes géneros integrantes de la familia Baculoviridae (Nucleopolyhedrovirus y Granulovirus) están orientados no sólo a ampliar la comprensión de los mecanismos de patogénesis viral, sino también, a optimizar su uso como agentes de biocontrol.

En tal sentido, en las últimas décadas se han registrado grandes avances en relación con el mejoramiento de la eficiencia de los nucleopoliedrovirus mediante ingeniería genética, encarándose investigaciones tendientes principalmente hacia el aumento de la velocidad de acción y ampliación el rango de hospedadores susceptibles, manteniendo las cualidades propias de los baculovirus en relación a su inocuidad hacia organismos no blanco (Chen et al., 1998; Maeda, 1989a; b; Zuidema et al., 1989). En la actualidad, este mejoramiento está orientado hacia la expresión de genes propios de los insectos o genes virales que alteren la fisiología del insecto blanco (Inceoglu et al, 2006).

Entre ellos, un gen con capacidad para aumentar la infectividad se describió en otra familia de virus entomopatógenos, los Entomopoxvirus (EPV). En estos, el cuerpo de oclusión viral está constituido por una proteína denominada esferoidina. Esta proteína presentó una alta homología respecto a secuencias obtenidas de baculovirus, a las que se designó como gp37 (Vialard et al., 1990). Estudios posteriores demostraron que la homología con la esferoidina era incorrecta, debido a que en los procesos de purificación de estos cuerpos de oclusión, la misma se encontraba contaminada con otros cuerpos cristalinos fusiformes constituidos por proteínas a las que se denominó fusolins (fusolinas) (Fig 3.1) (Gauthier et al., 1995). Por lo tanto, entre las fusolinas de los entomopoxvirus y gp37 de los baculovirus se estableció una relación determinada por la similitud a nivel de secuencia, no siendo muy claros hasta el momento los orígenes de este vínculo.

Tanto las secuencias aminoacídicas procedentes de los entomopoxvirus, como la descriptas inicialmente por Vialard y col. (1990) para AcMNPV, poseen 5 regiones de alta homología, así como potenciales sitios de glicosilación (Gauthier et al., 1995; Vialard et al., 1990). Según este estudio, el ORF está bajo un promotor de 
expresión. Si bien ambas familias virales no se encuentran vinculadas filogenéticamente, se postula un origen común de las fusolinas y las gp37 baculovirales (Vialard et al., 1990).
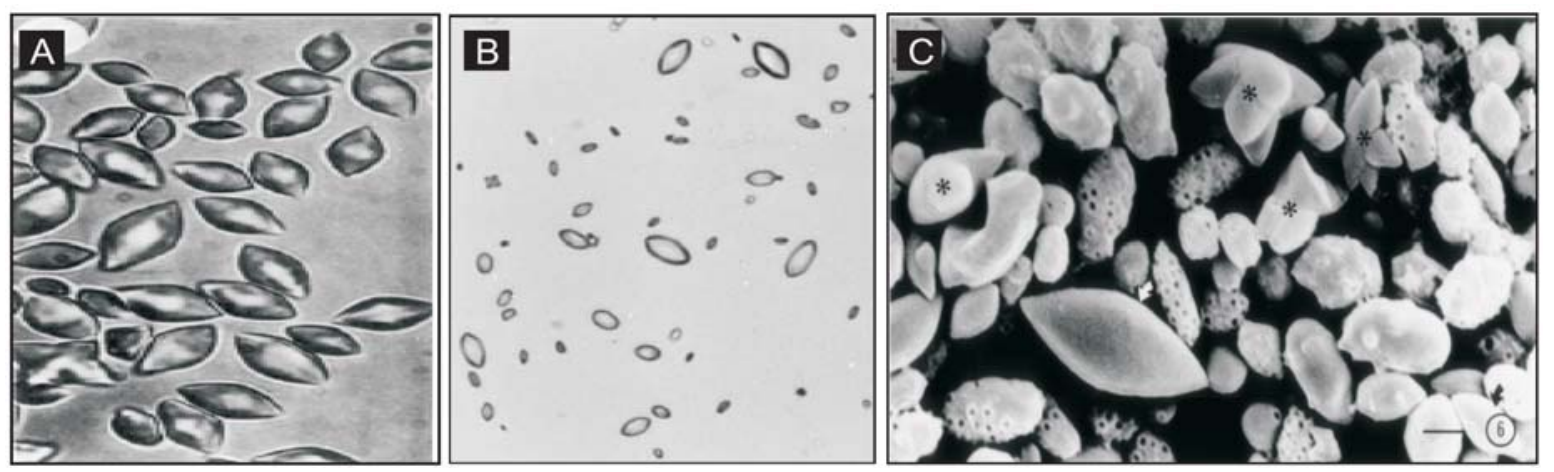

Fig 3.1. Morfología de los cristales de fusolinas obtenidas a partir de diferentes insectos infectados con entomopoxvirus (Fuente: A. Gauthier et al., 2005; B. Wijonarko et al., 1998; C. Lai-Fook et al., 2000).

Posteriormente, los estudios sobre GP37 estuvieron orientados a dilucidar su ubicación subcelular y su función en el ciclo de infección baculoviral. De esta manera su presencia comenzó a ser descripta en otros baculovirus, principalmente en los NPVs. Se demostró que GP37 del nucleopoliedrovirus Orgyia pseudosugata (OpMNPV) posee las regiones conservadas descriptas por Vialard y col. (1990) y que la región más conservada está presente en el extremo amino terminal, mientras que el extremo carboxilo muestra una mayor variabilidad (Gross et al., 1993). Estas observaciones fueron válidas para todas las secuencias descriptas posteriormente. A diferencia de lo encontrado en la descripción de AcMNPV, en OpMNPV la proteína GP37 no se encuentra asociada a la poliedrina, aunque se la encuentra altamente concentrada en el citoplasma formando cuerpos de inclusión (Gross et al., 1993). Esta última característica solo fue descripta nuevamente en el nucleopoliedrovirus Choristoneura fumiferana DEF (CfDEFNPV) (Li et al., 2000). Las causas que determinan la formación de inclusiones en algunos NPVs no están muy claras, asociándose la ausencia de cristalización de GP37 en otros virus, a un bajo nivel de expresión proteico (Li et al., 2003). Los estudios con tunicamicina indican que se trata de una glicoproteína (Phanis et al., 1999). Datos posteriores surgidos del estudio de gp37, le atribuyeron un papel importante en el proceso de 
duplicación del DNA viral debido al alto grado de conservación de la secuencia, su glicosilación y los dominios encontrados (Liu \& Carstens, 1996). Sin embargo, trabajos realizados con mutantes en los cuales gp37 fue deleteado, demostraron que no es esencial en el ciclo de replicación viral (Cheng et al., 2001).

Por otra parte, ensayos llevados a cabo con fusolinas evidenciaron que era capaz de potenciar la infección cuando estos cuerpos proteicos eran administrados junto a otros virus (Mitsuhashi et al., 1998; Wijonarko \& Hukuhara, 1998). Los siguientes trabajos centraron su atención sobre su acción sobre la MP del hospedador.

Más recientemente, se demostró que la GP37 de baculovirus presenta diferentes grados de glicosilación, que puede estar o no asociada a los cuerpos de oclusión, que el promotor es predominantemente tardío pero puede tener motivos tempranos en algunos casos, que están muy conservadas las 6 cisteínas aparentemente responsables de formaciones cristalinas en algunos hospedadores. Además, las 5 regiones conservadas (inicialmente descriptas en Autographa californica MNPV por Vialard y col., 1990) presentan un dominio de unión a quitina tipo 3, diferente al tipo 2 de las mucinas. La capacidad de unirse a la quitina de la membrana peritrófica quedó demostrada en ensayos realizados con GP37 de Spodoptera litura MNPV (Li et al., 2003).

En el caso de las fusolinas de EPV se ha demostrado alteran la estructura de la membrana peritrófica permitiendo de esta manera un mayor pasaje de viriones al sitio de replicación viral (Mitsuhashi et al., 2007). Sin embargo, en baculovirus no existen estudios que verifiquen la misma actividad de GP37.

Por otra parte, los antecedentes indican que genes hallados en el genoma de los baculovirus podrían tener su origen en otros organismos incluido el propio huésped (Wang et al., 2004b). La homología entre fusolinas y GP37 hace suponer un origen común (Vialard et al., 1990), no muy difícil de imaginar conociendo que representantes de ambas familias virales, esto es Entomopxviridae y Baculoviridae, pueden ser aislados de un mismo hospedador (Heliothis armigera o Choristoneura fumiferana , por ejemplo) (Dall et al., 1993; Lu et al., 2002);(de Jong et al., 2005; Lauzon et al., 2005; Li et al., 1997). Los análisis de filogenia que incluyen ambas familias los muestran como dos grupos bien separados (Phanis et al., 1999), pero los mismos no fueron realizados incluyendo la gran cantidad de secuencias 
disponibles en la actualidad en las bases de datos, ni tampoco incluyen organismos como las bacterias. Estas, por ejemplo, poseen proteínas con secuencias homólogas a las fusolinas y gp37, denominadas chitin binding proteins (cbps) cuya función parece estar involucrada en la optimización del proceso de degradación de la quitina (Vaaje-Kolstad et al., 2005).

Los resultados expuestos en el capítulo anterior indican la existencia de sinergismo entre el virus de AgMNPV y EpapGV cuando son aplicados de forma conjunta sobre larvas de Anticarsia gemmatalis. Además, se verificó la ausencia de genes vef. Por tal motivo, se consideró de interés realizar la caracterización del homólogo a gp37 encontrado en el genoma de EpapGV y establecer su posible participación en los efectos observados en los ensayos in vivo. 


\section{Materiales y métodos}

Insectos. Las larvas de E. aporema, empleadas para la multiplicación de virus, fueron provistas por el insectario del IMYZA-INTA, Castelar. La cría de los insectos se realizó bajo condiciones controladas de temperatura $\left(26 \pm 1^{\circ} \mathrm{C}\right)$, humedad relativa $(50-70 \%)$, fotoperíodo $(14: 10 \mathrm{~L} / \mathrm{O})$ y fue mantenida en dieta artificial (Greene et al., 1976).

Células de insectos. Células de Trichoplusia ni (HighFive) (Wickham et al., 1992) y Spodoptera frugiperda SF9 (Vaughn et al., 1977) fueron mantenidas a $27^{\circ} \mathrm{C}$ en medio TC100 suplementado con $10 \%$ de suero fetal bovino (BIOSER).

Virus. EpapGV fue multiplicado en larvas de cuarto estadio de su respectivo hospedante. La propagación se realizó por contaminación superficial de la dieta (sin formaldehído) con cuerpos de inclusión $\left(1 \times 10^{3} \mathrm{OBs} / \mathrm{mm}^{2}\right)$. Las larvas fueron mantenidas bajo condiciones controladas de temperatura $\left(26 \pm 1^{\circ} \mathrm{C}\right)$ y humedad $(50 \%)$ hasta el momento de recolección del material infectado.

Extracción de DNA de EpapGV. Las larvas recolectadas fueron maceradas en baño hielo agua, esta mezcla se filtró a través de una gasa colocada en un tubo eppendorf de $0,5 \mathrm{ml}$ perforado en su base. El filtrado fue tratado con $\mathrm{Na}_{2} \mathrm{CO}_{3} \mathrm{a}$ concentración final de $0,1 \mathrm{M}$ durante $30 \mathrm{~min}$, se neutralizó la solución mediante agregado de Tris- $\mathrm{HCl}(\mathrm{Ph} 6,2)$. Las muestras fueron hervidas por 5 min y se utilizó 1 $\mu \mathrm{l}$ de esta solución para la reacción de PCR (Manzán et al., 2008).

Extracción de cuerpos de oclusión a partir de larvas infectadas con EpapGV. Las larvas infectadas fueron recolectadas y maceradas con la ayuda de un mortero, se agregó agua para ayudar a la homogeneización, esta mezcla se incubó a temperatura ambiente una semana. Posteriormente, se filtró la mezcla a través de gasa, se midió el volumen y se agregó SDS a concentración final de $0,1 \%$. Se centrifugó 2 min a 2000 rpm en rotor SS34 (Sorvall) para eliminar todos los restos celulares. El sobrenadante se ubico sobre un gradiente de sacarosa de $35 \%$ a $65 \%$ 
y se centrifugó por una hora a $32.500 \mathrm{xg}$. La banda blanca correspondiente a los OBs se recupero y se diluyo en tres volúmenes de agua destilada y se centrifugo por 1 hora a $20.000 \mathrm{xg}$, este último paso se repitió tres veces para eliminar restos de sacarosa. El pellet fue finalmente resuspendido en agua destilada.

Secuenciación de gp37 de EpapGV. En base a la secuencia parcial del ORF de gp37 (Parola et al., 2002) se diseñó un primer de secuencia 5'CTGACAATCTTGGCACACC-3' (T 53,7 ${ }^{\circ} \mathrm{C}$ ) para continuar con la secuenciación. El análisis de la secuencia obtenida permitió identificar un codón de terminación y por lo tanto obtener la secuencia completa del ORF.

Amplificación por PCR del ORF de gp37 de EpapGV. Una vez obtenida la secuencia completa del ORF se diseñaron primers específicos para la amplificación de gp37 de EpapGV gp37-up-EcoRI (5'-GGAATTCCAGATATGATAGTACGATAAT ATTG'-3) gp37-down-Pstl (5'-AACTGCAGTTAAAACTCGTCATTTTGT'-3). Ambos primers fueron diseñados conteniendo los citados sitios de restricción (subrayados) El producto de amplificación fue analizado por electroforesis en gel de agarosa al $1 \%$ y visualizado bajo luz UV mediante tinción con bromuro de etidio.

Análisis filogenético. La secuencia teórica aminoacídica de GP37 de EpapGV fue comparada con un total de 37 secuencias obtenidas por BLAST en el EMBL/GenBank (Tabla 3.2). Las mismas se alinearon mediante el uso del programa CLUSTAL X (Thompson et al., 1997) con los siguientes parámetros: pairwise alignments; slow, gap opening 10, gap extension 0 \pm 1 , matrix BLOSUM, 30; multiple alignments; gap opening 10, gap extension 0 \pm 05 . Las 38 secuencias de proteínas completas se utilizaron en el alineamiento final. El análisis filogenético se realizó con el método del vecino más cercano (Neighbor-joining, $\mathrm{NJ}$ ) usando el conjunto de programas de MEGA 3.1 (D. L. Swofford). Los valores de bootstrap en NJ se obtuvieron después de 500 replicaciones. 
Tabla 3.2. Abreviaturas y números de acceso en GenBank de los organismos utilizados en este trabajo.

\begin{tabular}{|c|c|c|}
\hline & Abreviatura & $\mathrm{N}^{\circ}$ de acceso en GenBank \\
\hline \multicolumn{3}{|l|}{ Nucleopolyhedrovirus (NPV) } \\
\hline Agrotis ipsilon MNPV & AgipMNPV & NC_011345 \\
\hline Agrotis segetum NPV & AgseNPV & NC_007921 \\
\hline Autographa californica MNPV & AcMNPV & L22858 \\
\hline Bombyx mori NPV & BmNPV & L33180 \\
\hline Choristoneura fumiferana DEF MNPV & CfDEFMNPV & NC_005137 \\
\hline Chrysodeixis chalcites NPV & ChchNPV & YP_249671 \\
\hline Ecotropis obliqua NPV & EcoNPV & NC_008586 \\
\hline Epiphyas postvittana NPV & EppoMNPV & AY043265 \\
\hline Helicoverpa zea MNPV & HzMNPV & AF334030 \\
\hline Hyphantria cunea NPV & HycuNPV & NC_007767 \\
\hline Lymantria dispar MNPV & LdMNPV & AF081810 \\
\hline Mamestra brassicae MNPV & MbMNPV & AF108960 \\
\hline Mamestra configurata NPV & MacoNPV & U59461 \\
\hline Maruca vitrata MNPV & MaviMNPV & NC_008725 \\
\hline Plutella xylostella MNPV & PlxyMNPV & DQ457003 \\
\hline Rachiplusia ou MNPV & RouMNPV & NC_004323 \\
\hline Spodoptera exigua MNPV & SeMNPV & AF169823 \\
\hline Trichoplusia ni NPV & TniNPV & NC_007383 \\
\hline \multicolumn{3}{|l|}{ Granulovirus (GV) } \\
\hline Cydia pomonella $\mathbf{G V}$ & $\mathrm{CpGV}$ & U53466 \\
\hline Heliothis armigera GV & $\mathrm{HaGV}$ & D28558 \\
\hline Pieris rapae $\mathbf{G V}$ & PieraGV & GQ884143 \\
\hline Pseudaletia unipuncta GV & PsunGV & EU678671 \\
\hline Xestia c-nigrum GV & $\mathrm{XcGV}$ & AF162221 \\
\hline \multicolumn{3}{|l|}{ Entomopoxvirus (EPV) } \\
\hline Anomala cuprea EPV & AncuEPV & AB000780 \\
\hline Choristoneura biennis EPV & CbEPV & M34140 \\
\hline Choristoneura fumiferana EPV & CfEPV & U76536 \\
\hline Heliothis armigera EPV & $\mathrm{HaEPV}$ & L08077 \\
\hline Melolontha melolontha EPV & MmEPV & X77616 \\
\hline Pseudaletia separata EPV & PsEPV & D50590 \\
\hline \multicolumn{3}{|l|}{ Bacteria } \\
\hline Serratia marcescens & Serratia & BAA31569 \\
\hline Aeromonas hydrophila & Aeromonas & YP_855149 \\
\hline Vibrio coralliilyticus & Vibrio & ZP_05885129 \\
\hline Pseudoalteromonas tunicata & Pseudoalteromonas & ZP_01132952 \\
\hline Burkholderia thailandensis & Burkholderia & YP_443713 \\
\hline
\end{tabular}


Expresión de EpapGV gp37 en células de insectos. El producto obtenido por amplificación correspondiente al ORF completo de gp37 fue digerido con las enzimas EcoRI y Pstl (Promega) y clonado en el vector pBacPack 8 (Invitrogen) cortado con el mismo par de enzimas. Una vez ligados inserto y vector, se transformaron células $\mathrm{DH} 5 \alpha$ electrocompetentes. Las colonias, seleccionadas mediante la utilización de ampicilina, fueron chequeadas mediante colony PCR usando los primers que amplificaron el ORF y mediante los primers bac1 (5'AACCATCTCGCAAATAAATA-3') y bac2 (5'-AAGCGCTAGATTCTGTGCGT3') complementarios a regiones externas y flanqueantes a la región de inserción del ORF. El plásmido obtenido se denominó pbgp37 y fue utilizado para la generación de virus recombinantes que permiten la expresión del ORF clonado. El sistema de recombinación empleado se basa en el uso de un bácmido del virus AcMNPV (bacGOZA) el cual ha sido modificado genéticamente. Entre las modificaciones se incluye la inserción de un replicón mini-F, que permite la posibilidad de que este genoma sea mantenido en bacterias y la deleción parcial del ORF 1629 lo cual ocasiona la inviabilidad de este genoma. La porción faltante de este ORF esta incorporada en el plásmido de transferencia, por lo cual solo la ocurrencia del evento de recombinación homologa entre plásmido y bácmido en células transfectadas con ambos, posibilita la obtención de un recombinante viable. La presencia del recombinante es evidenciada por la aparición de poliedros (OBs) en las células co-transfectadas, ya que el bácmido posee el ORF de poliedrina bajo promotor de p10. El vector de transferencia transfiere al bácmido el ORF de interés bajo el promotor de poliedrina por lo cual se espera un alto nivel de expresión proteica. La viabilidad del recombinante solo es posible ante un evento de recombinación que indica la transferencia del ORF clonado en el vector de transferencia por lo cual este sistema es altamente eficiente en la generación de virus como vectores de expresión.

Las células SF-9 (sembradas en placas de $35 \mathrm{~mm}$ de diámeto; $0.5 \times 10^{6}$ células) fueron transfectadas con el plásmido pbacgp37, el DNA del bacGOZA y el reactivo de transfección Cellfectin (Invitrogen) siguiendo las especificaciones y recomendaciones del fabricante (Fig.3.3). Las células fueron mantenidas a $27^{\circ} \mathrm{C}$ por $4 \mathrm{~h}$ con la mezcla lípidos-DNA y luego la mezcla fue reemplazada por medio TC-100 suplementado con $10 \%$ de suero fetal bovino. La incubación a $27^{\circ} \mathrm{C}$ se 
extendió hasta observar la presencia de células con poliedros. El sobrenadante de la transfección fue utilizado para reinfectar células Sf9 y el segundo pasaje se realizó sobre células de Trichoplusia ni (HighFive).

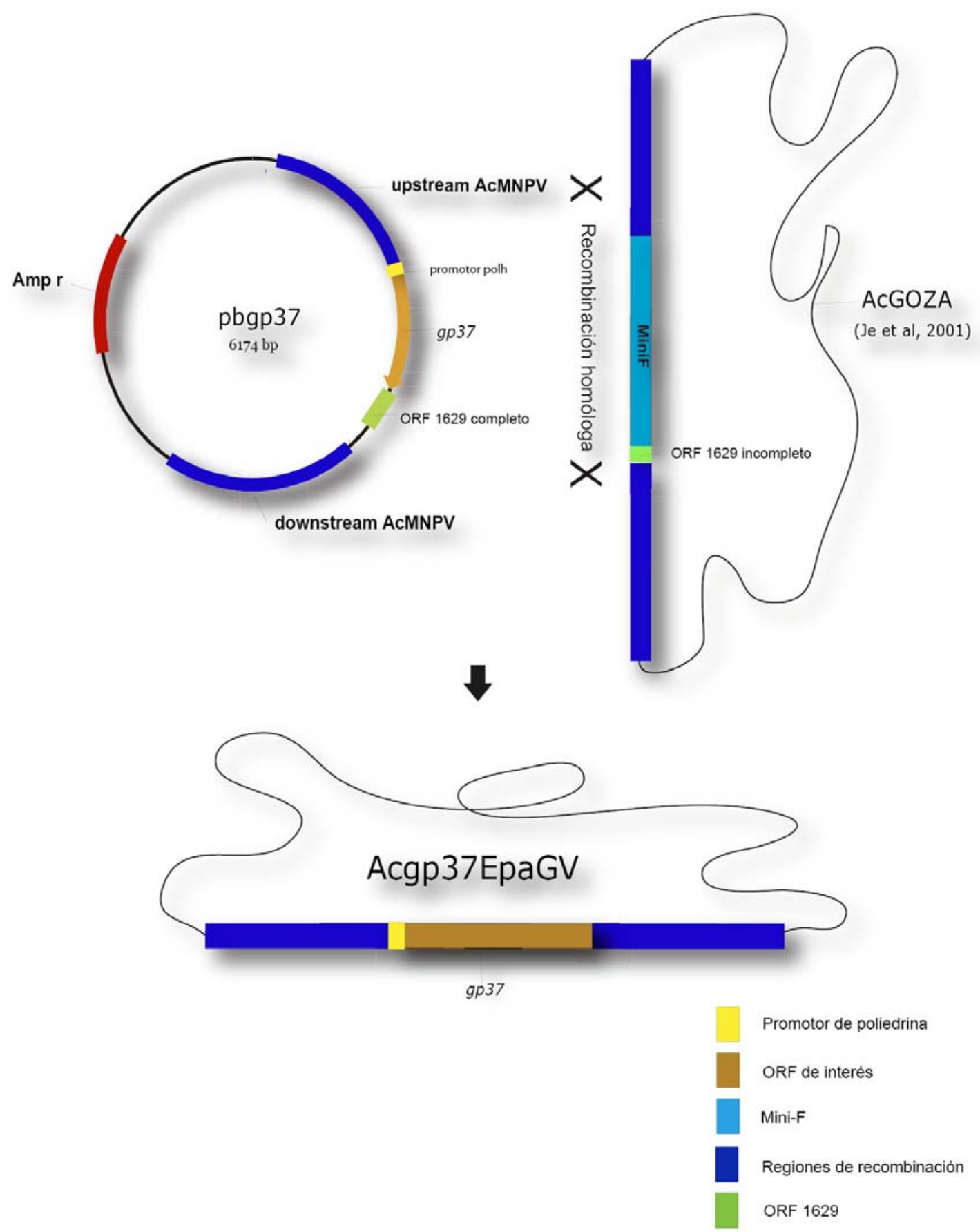

Fig. 3.3. Generación del recombinante Acgp37EpapGV mediante cotransfección de un plásmido de transferencia portador del ORF de interés y DNA de un bácmido de AcMNPV. 
Purificación de cuerpos de oclusión del rAcgp37EpapGV a partir de cultivos celulares. Monocapas de células infectadas con el virus rAcgp37EpapGV fueron resuspendidas 96 horas posinfección y centrifugadas a $6000 \mathrm{rpm}$ durante $5 \mathrm{~min}$. Posteriormente los pellets celulares se resuspendieron en un buffer de lisis y se sometieron a ultracentrifugación en gradientes de sacarosas. La fracción correspondiente a los poliedros fue extraída y lavada tres veces con agua destilada para eliminar los restos de sacarosa. La concentración de los OBs purificados se determinó mediante el uso de un hemocitómetro (cámara de Neubauer)

Producción de anticuerpos. Se separaron las proteínas a partir de extractos celulares infectados con Acgp37EpapGV, mediante SDS-PAGE. La banda correspondiente a GP37 fue retirada del gel y deshidratada a temperatura ambiente. Con ayuda de un mortero se pulverizó el fragmento de gel conteniendo GP37 para posteriormente ser resuspendido en adyuvante de Freund completo. Se inocularon ratones C57BL/6J por vía subcutánea, respetando el siguiente protocolo: día 0 , inoculación con adyuvante de Freund completo; día 15, inoculación con adyuvante de Freund incompleto y día 30, con adyuvante de Freund incompleto. Al día 45 se procedió al sangrado de los animales y a la extracción del suero.

Análisis mediante SDS-PAGE y Western Blot. Las células infectadas con el recombinante Acgp37EpapGV fueron levantadas 72 hs postinfección, lavadas dos veces con buffer PBS, centrifugadas y resuspendidas en SDS-PAGE sample buffer. Posteriormente, las muestras fueron separadas por electroforesis en gel de poliacrilamida al 10\% (SDS-PAGE) (Laemmli, 1970), usando el equipo Mini-protean Il (Bio-Rad). Las proteínas se transfirieron a una membrana de PVDF (ImmobilonPsq; Millipore, Bedford, MA) usando un aparato Trans-Blot $囚$ SD Semi-dry Transblot (Bio-Rad). La transferencia se realizó a $15 \mathrm{~V}$ por $30 \mathrm{~min}$. Posteriormente, las membranas se incubaron en una solución de bloqueo (PBS conteniendo $5 \%$ de leche descremada) por $1 \mathrm{~h}$ a temperatura ambiente. Las membranas fueron incubadas durante 1 hora a temperatura ambiente con una dilución 1:5.000 del anticuerpo anti-fusolin AcEPV (Mitsuhashi et al., 2007) y se lavó tres veces con PBS que contenía $0,05 \%$ de Tween 20 . A continuación, la membrana fue incubada $1 \mathrm{~h}$ con una dilución 1:5.000 de anticuerpos anti-lgG de ratón conjugados a HRP (Santa Cruz Biotechnology). Posteriormente se lavaron en PBS (0,05\% de Tween 20) y 
revelada con DAB (Sigma) y $\mathrm{H}_{2} \mathrm{O}_{2}$. Como controles se utilizaron células HighFive sin infectar y células infectadas con un recombinante de AcGOZA generado para expresar proteínas de virus (proteínas Z y GPC del virus Junín) no relacionadas con los baculovirus.

Secuenciación del extremo amino-terminal. Las proteínas procedentes de células infectadas con el virus Acgp37EpapGV fueron separadas por SDS-PAGE y transferidas a una membrana de nitrocelulosa (Trans-Blot ${ }^{\circledR} S D$, Semi-Dry Electrophoretic Transfer, BioRad). Posteriormente, la banda del peso molecular acorde al esperado se separó de la membrana y se envió al Instituto LANAIS-PRO (UBA) para su secuenciación N-terminal mediante el método de Edman.

Disolución de cuerpos de oclusión en $\mathrm{Na}_{2} \mathrm{CO}_{3}$. y análisis mediante Western Blot y microscopía electrónica de barrido. Los gránulos provenientes de larvas infectadas con EpapGV se resuspendieron en agua destilada. Alícuotas de $1 \mathrm{ml}$ de $1,5 \times 1010 \mathrm{OB} / \mathrm{ml}$ fueron tratadas con una solución de $\mathrm{Na}_{2} \mathrm{CO}_{3}$ (concentración final de $0,1 \mathrm{M}$ ) a diferentes tiempos (10 $\mathrm{min}, 6 \mathrm{~h}$ y $18 \mathrm{~h}$ ); la reacción de disolución fue detenida con el agregado de ácido clorhídrico diluido. Posteriormente cada muestra se centrifugó 5 min a 14000 rpm y el pellet resuspendido en 30 ul agua destilada. De cada tratamiento se tomaron 5 ul y se depositaron sobre placas de cobre para su metalización con oro y su posterior análisis mediante microscopia electrónica de barrido. El resto del volumen se utilizó para análisis mediante Western blot. 


\section{Resultados y discusión}

\section{Secuenciación y caracterización de gp37 de EpapGV}

El estudio de la secuencia parcial disponible del genoma de EpapGV (Parola et al., 2002), indicó la presencia de gp37 flanqueado por el ORF odv-e18 por un lado y catepsina ( $v$-cath) y quitinasa (chiA) en el otro extremo (Fig.3.5).

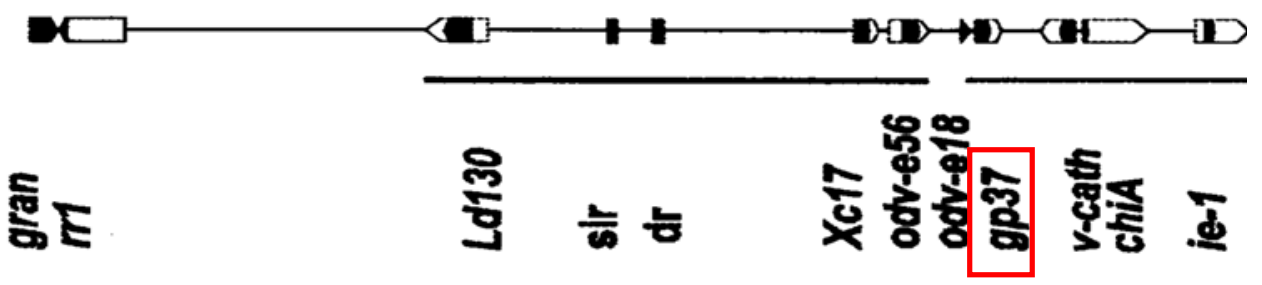

Fig. 3.5. Regiones flanqueantes de gp37 (en recuadro) en el genoma de EpapGV. Extraído de Parola et al., 2003.

Con la secuencia disponible (de aproximadamente 200 nucleótidos) se diseñó un primer específico que permitió encontrar un codón de stop y de esta forma obtener la secuencia completa del ORF de gp37. Del análisis de la secuencia obtenida se dedujo que el ORF posee 669 nt y que el codón de inicio esta bajo regulación de un promotor tardío (Figura 3.6).

La traducción teórica completa de gp37 de EpapGV determinó que codifica para una proteína de 221 aminoácidos de aproximadamente $25,4 \mathrm{kDa}$, en cuyo extremo amino terminal posee una región hidrofóbica que se correspondería con un péptido señal (Dall et al., 1993), seguido por un motivo His-Gly-Tyr. Este motivo es característico de las proteínas maduras tipo fusolinas y constituiría la secuencia consenso de clivaje del péptido señal. 
Met lle Val Leu lle lle Leu Leu Ser lle Val Ser Val His Gly His Gly Tyr Met Val Gin Pro Leu Ala Arg Gin Arg Tyr

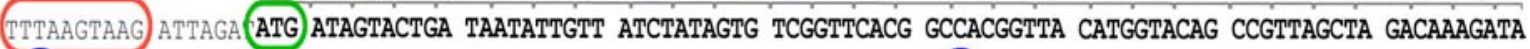
T. Cys Tyr Gln His Gin Asp Tyr Tyr Trp Pro lle Asn Gly Asp Gly lle Lys Asp Glu Ala Cys arg Ala Ala Phe Thr His Val Ala Leu Arg Ser Asn

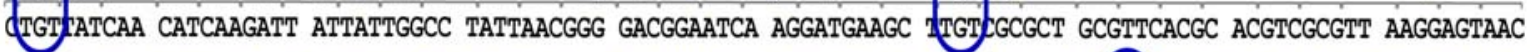
Glu Val Ser Ala Gin Tyr Met Phe Asn Gin Tyr Thr Glu Tyr Ala Ala Asn His Leu lle Gln His Thr Leu Cys Gly Ala Gly Ala Asn Asp Ser Asn Ala GAGGTIAGCG CACAATACAT GTTCAACCAG TACACCGAAT ATGCGGCGAA TCATCTCATA CAACACACAC Tn TGCSGGG AGGCGCTAAT GACTCCAACG -Ale Pro Phe Gly Asp Lys Ser Gly Val His Leu Pro Leu Thr lle Leu Ala His His Leu Leu Thr His Gly Pro Asn Glu Leu lle Phe Pys Pro Thr Ala. CGCCGTTGG CGACAAGTCG GGCGTTCACT TACCGCTGAC AATCTTGGCA CACCACCTTC TCACACATGG ACCCAACGAG CTTATATTC GICCAACCGC Ale Val His Glu Ser Ser Tyr Phe Glu Val Tyr lle Thr Gln Pro Lys Tyr Asn Tyr Ser Glu Pro lle Thr Trp Asn Asn Leu Met Leu lle Tyr Lys Gln CGTTCATGAA TCCAGCTATT TCGAGGTGTA CATAACTCAA CCAAAATACA ACTATTCCGA ACCTATTACG TGGAACAACC TGATGTTGAT TTATAAACAA Gly Ser Val Leu Thr Lys Lys Lys Val Asp Asn Cys His Ser Asp Leu Val Tyr Thr Met Val Val Asp lle Pro Tyr Arg Asp Asn Lys Phe Val Leu Phe GGCTCGGTTC TGACTAAGAA AAAAGTTGAC AAITGThACA GCGACCTGGT CTACACCATG GTGGTCGACA TTCCATATAG AGATAATAAA TTCGTTTTAT -Phe Thr Arg Trp Gin Arg Glu Asp lle Met Gly Glu Gly Phe Tyr Asn Cys Ala Asp Leu Gin Leu Thr Gln Asn Asp Glu Phe ... TCACTAGGTG GCAGCGTGAA GATATAATG GTGAGGGATT TTATAAqGG GCAGACCTTC AATTAACACA AAATGACGA TTITAA

Fig. 3.6: Secuencia nucleotídica y aminoacídica completa del ORF gp37. Con borde rojo :Promotor tardío (TTTAAGTAAG). Con borde verde: codones de inicio (ATG) y detención (TAA).con borde azul: cisteínas (Cys).

La secuencia proteica obtenida de EpapGV se comparó con secuencias disponibles en las diferentes bases de datos mediante el programa BLASTP. El alineamiento de GP37 de EpapGV con las secuencias obtenidas reveló que GP37 de CpGV es la proteína con mayor porcentaje de similitud (63\%), encontrándose también una similitud significativa con fusolinas de EPV y las denominadas chitin binding proteins (CBP) codificadas en algunas bacterias (Fig. 3.7). El análisis de GP37 de EpapGV, indicó que presenta un dominio de unión a quitina entre los aa 2 y 214 , clasificado como un Chitin-binding domain 3 (base de datos INTERPRO, número de acceso: IPR 4302). Dentro del mismo, GP37 presenta las cinco regiones conservadas descriptas por Vialard y col. (1990) (Fig.3.7). Estas no están totalmente conservadas en las CBP de bacterias, siendo las regiones 4 y 5 las menos variables en todas las secuencias analizadas.

En GP37 de EpapGV también se verificó la presencia de 6 cisteínas (Cys) que podrían estar involucradas en la formación de puentes disulfuros (Liu \& Carstens, 1996) (Fig. 3.6 y 3.7) y se observó la presencia de prolinas cercanas a las Cys mencionadas anteriormente. Notablemente, las cisteínas 4 y 5 están ausentes en las CBP de bacterias. Con respecto a otros motivos, la GP37 de EpapGV presenta dos motivos potenciales de glicosilación también descriptos en otras proteínas de esta familia. 


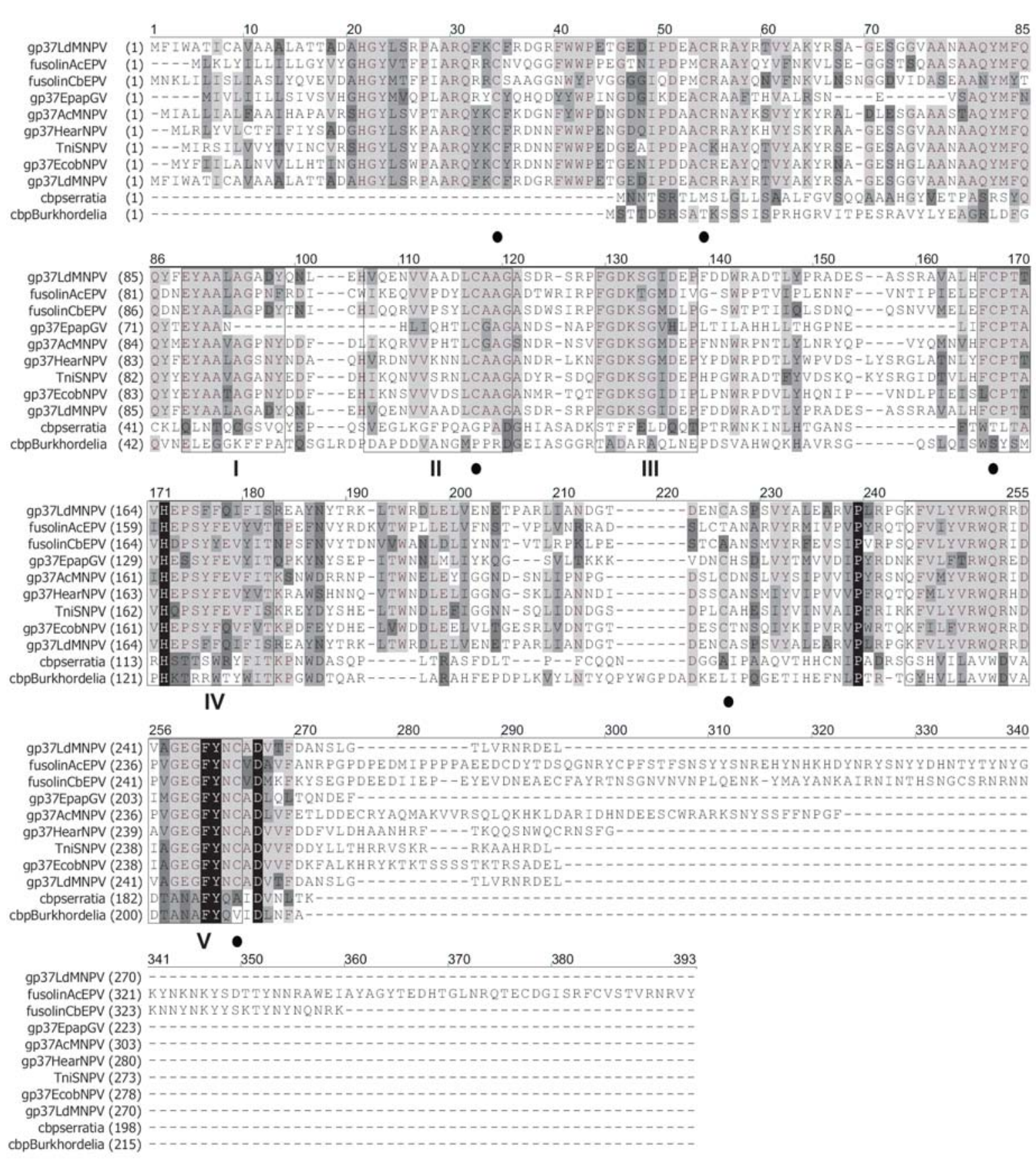

Fig. 3.7: Comparación esquemática de las secuencias aminoacídicas indicando con recuadros y números romanos (I-V) las cinco regiones descriptas por Vialard y col. (1990). Los puntos en negro debajo del alineamiento indican la presencia de cisteínas (C). Referencias: en fondo negro y letras blancas indican total identidad con secuencia consenso (no mostrada); fondo gris claro y letras negras indican alta identidad con secuencia consenso; fondo gris oscuro y letras negras muestran baja identidad con secuencia consenso y fondo blanco con letras negras residuos no similares a secuencia consenso. 
El análisis global de estas secuencias (GP37, fusolinas y CBP) en su conjunto muestra que poseen una longitud que va desde 200 aa a aproximadamente de 380 aa en baculovirus, hasta alcanzar una longitud cercana a los 400 aa en entomopoxvirus y algunas bacterias. El extremo amino-terminal es el más conservado y es donde ubica el dominio de unión a quitina. Recientemente en fusolinas de EPV, se demostró que en este extremo de la proteína se ubica la región responsable de la actividad tipo enhancin sobre la membrana (Takemoto et al., 2008). La región del extremo carboxilo se presenta sumamente variable en cuanto a secuencia y longitud (Li et al., 2003) (Fig. 3.8). En EPV este extremo es eliminado por la acción de enzimas presentes en el intestino medio y no posee ningún rol aparente en el aumento de la infectividad (Takemoto et al., 2008).

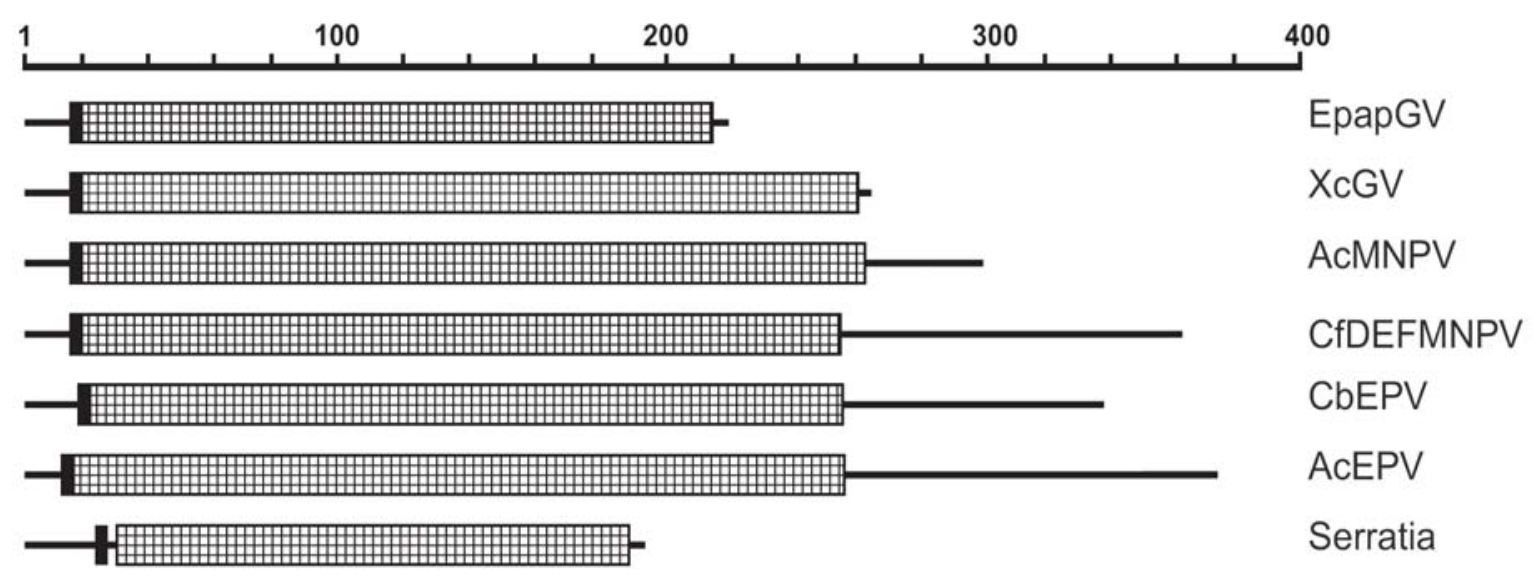

Fig. 3.8: Comparación esquemática de las secuencias aminoacídicas indicando longitud de las mismas y con rectángulo cuadriculado, la porción correspondiente al dominio de unión a quitina (Chitin-binding domain 3, INTERPRO database accesión number: IPR004302). El bloque en negro representa el sitio de clivaje del péptido señal y la línea negra indica la longitud en aa.

La secuencia aminoacídica completa deducida del ORF de gp37 de EpapGV muestra que es la más pequeña entre las de proteínas virales de este grupo, descriptas hasta el presente. Si bien posee una deleción entre las regiones 1 y 2 descriptas por Vialard y col. (1990), los dominios y señales característicos están presentes. El ORF está ubicado adyacente a los genes catepsina y quitinasa que juegan un rol importante en la degradación de la quitina en las etapas finales del ciclo infectivo y en la liberación de los cuerpos de oclusión en el medio ambiente. La 
disposición de estos tres genes está conservada en muchos de los baculovirus secuenciados hasta el momento. En las bacterias está demostrada una asociación funcional entre el homólogo a gp37 (las cbps) y las quitinasas, no demostrada hasta el momento en baculovirus (Techkarnjanaruk \& Goodman, 1999; Tsujibo et al., 2002; Watanabe et al., 1997).

\section{Análisis filogenético de GP37 y homólogos}

Es muy escaso el análisis filogenético que se describe en la bibliografía sobre esta familia de proteínas. El único realizado indica que los baculovirus y los entomopoxvirus (EPV) forman dos grupos claramente separados (Phanis et al., 1999). El mismo se realizó con un escaso número de secuencias (7 secuencias de NPV y 5 de EPV), sin secuencias de GVs ni de bacterias. En la actualidad se dispone de mayor cantidad de datos que nos permiten hacer un análisis más exhaustivo de las relaciones de estos organismos, basándonos en este gen y sus homólogos. Las secuencias (CBPs) de bacterias provienen en su mayoría de organismos del grupo taxonómico de las Gammaproteobacterias.

El análisis filogenético llevado a cabo en este trabajo incluye un total de 32 secuencias provenientes de baulovirus (NPVs y GVs), EPV y bacterias (Fig. 3.10). Los NPVs se agruparon acorde a lo descripto en otros análisis filogenéticos en los cuales se diferencian dos linajes (NPV I y NPV II) (Herniou \& Jehle, 2007). Los EPVs provenientes de lepidópteros (CbEPV, CfEPV, HaEPV y PsEPV) se separaron de los aislados de los coleópteros (AncuEPV y MmEPV). Contrario a lo esperado, los GVs no aparecen cercanos a los NPVs sino que se agrupan junto a los EPVs. Los GVs analizados se distribuyeron en dos grupos, por un lado XcGV, HearGV y PsunGV, cuyos hospedadores pertenecen a la Familia Noctuidae y por otro EpapGV, CpGV (hospedadores de la Familia Tortricidae) y PiraGV (de la Familia Pieridae).

Mediante el análisis filogenético se demuestra que el origen de este gen en los baculovirus sigue siendo incierto. La presencia de homólogos en entomopoxvirus y bacterias sugiere la posibilidad de eventos de transferencia horizontal de este gen entre estos grupos. Para el caso de los entomopoxvirus la suposición no es muy difícil de sostener ya que los EPV como los baculovirus poseen hospedadores 
comunes. como Choristoneura fumiferana y Heliothis armigera (Dall et al, 2001).En relación a la presencia de homólogos a gp37 en bacterias, está bien documentada la evidencia de que numerosos grupos de estos microorganismos viven como endosimbiontes en diferentes tejidos de lepidópteros $u$ otros grupos de insectos (Fukatsu et al., 2000; Broderik et al, 2004). No sería el primer caso de transferencia horizontal entre baculovirus y bacterias ya que otros trabajos sostienen que genes como la quitinasa fueron adquiridos partir de estas últimas (Wang et al., 2004a).

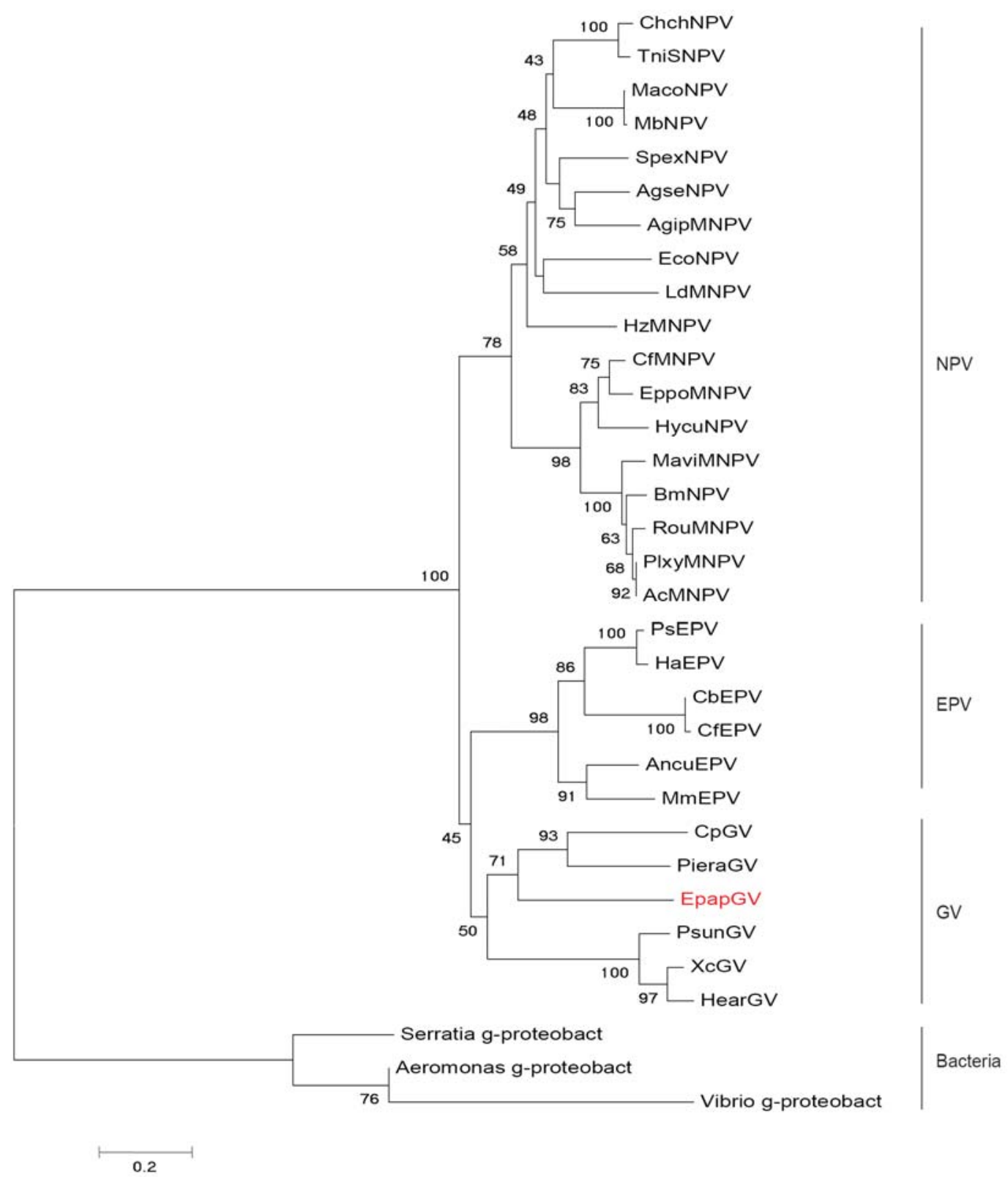

Fig.3.9. Análisis filogenético con 33 secuencias de organismos que poseen homólogos a gp37. A la derecha, el grupo en el cual se encuentra incluida cada secuencia 


\section{Expresión de GP37 en un sistema eucariota}

Habiendo obtenido la secuencia completa del gp37 de EpapGV, se diseñaron primers con sitios de restricción y se amplificó el ORF mediante PCR (Fig. 3.10). EI producto fue purificado, clonado en un vector de transferencia y cotransfectado en células de insecto Sf9 con un bácmido de AcMNPV (Je et al., 2001). Verificada la presencia de poliedros en la monocapa transfectada (Fig.3.11.A) se traspasó el sobrenadante de las mismas a células HighFive para proceder a la amplificación del virus.

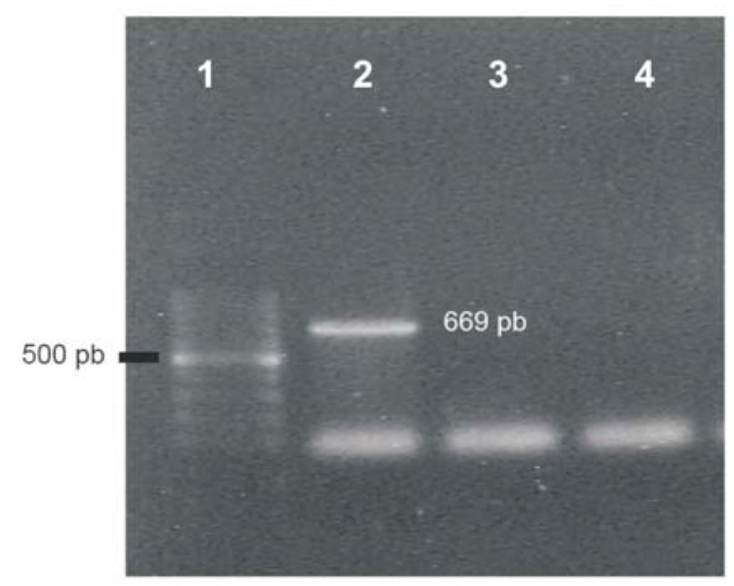

Fig. 3.10: PCR de amplificación de gp37 de EpapGV. El producto posee un tamaño de aproximadamente de $700 \mathrm{nt}$. De izquierda a derecha: calle 1: peso molecular (100 pb); calle 2: DNA EpapGV; calle 3: DNA AgMNPV; calle4: control negativo.

Los extractos de células (HighFive) infectadas con el virus Acgp37EpapgV se analizaron mediante SDS-PAGE (Fig. 3.11). La proteína expresada posee un peso acorde al calculado de manera teórica (aproximadamente $25 \mathrm{kDa}$ ). Como controles de la expresión se utilizaron otros recombinantes (AcGOZA) con ORFs no relacionados a gp37 (baculovirus que expresan genes $Z$ y GPC de virus Junín).

Con el objetivo de confirmar la identidad proteica de las bandas observadas por SDS-PAGE se procedió a la secuenciación de banda inferior. Los aminoácidos secuenciados desde el extremo aminoterminal confirmaron que la banda extraída se corresponde con la secuencia teórica de GP37 de EpapGV (datos no mostrados). 


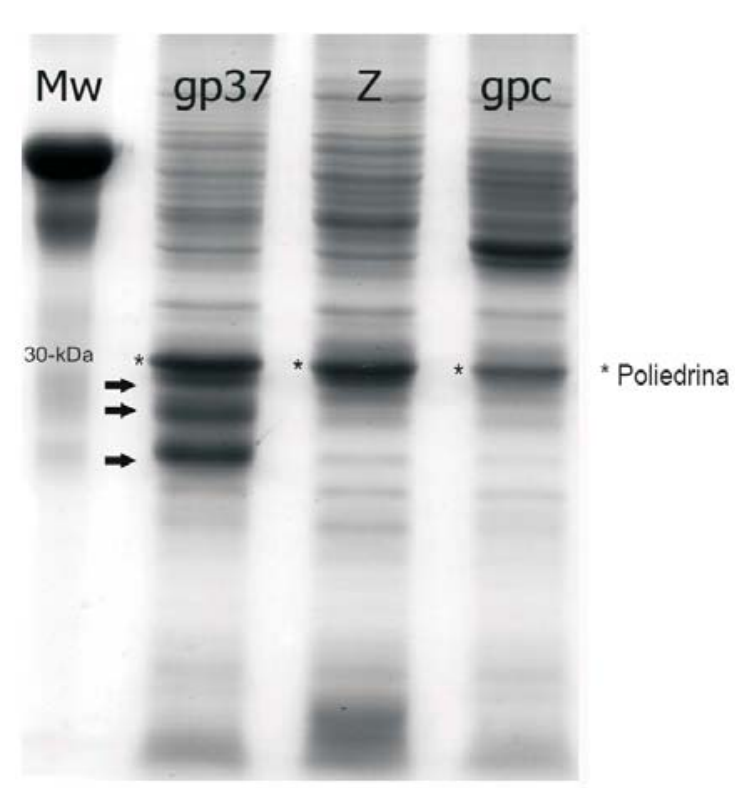

Fig. 3.11. SDS-PAGE con lisados de células infectadas con diferentes recombinantes de AcMNPV (AcGOZA). Flechas: bandas correspondientes a GP37. Asteriscos indican banda correspondiente a la poliedrina en cada una de las muestras.

Teniendo una alta expresión de GP37 se procedió a la obtención de anticuerpos en ratones. Una vez extraído el plasma, se evaluó los mismos mediante Western Blot sobre extractos proteicos de células infectadas con Acgp37EpapGV. Los resultados demostraron que los anticuerpos eran poco específicos, por lo cual se procedió a realizar un segundo intento de obtención. El segundo intento resultó poco satisfactorio y teniendo en cuenta el alto grado de similitud con las fusolinas descriptas en EPV, se solicitaron anticuerpos anti-fusolina de AncuEPV que fueron gentilmente enviados por el Dr. Wataru Mitsuhashi (National Institute of Agrobiological Sciences, Japón). El uso de estos anticuerpos permitió comprobar no solamente la identidad de GP37 de EpapGV (Fig. 3.12.A) sino también la similitud que existe a nivel de secuencia entre las fusolinas de los EPV y GP37 de granulovirus.

Mediante el uso de tunicamicina en cultivos celulares infectados con Acgp37EpapGV y Western blot, se pudo determinar que las bandas adicionales observadas en el análisis mediante SDS-PAGE (Fig. 3.11.) correspondian a diferentes grados de glicosilación del polipéptido. El agregado del inhibidor determinó la desaparición de las bandas de tamaños aparentes mayores y la observación de una única banda que se correspondería a GP37 de EpapGV sin glicosilar (Fig. 3.12.B). 


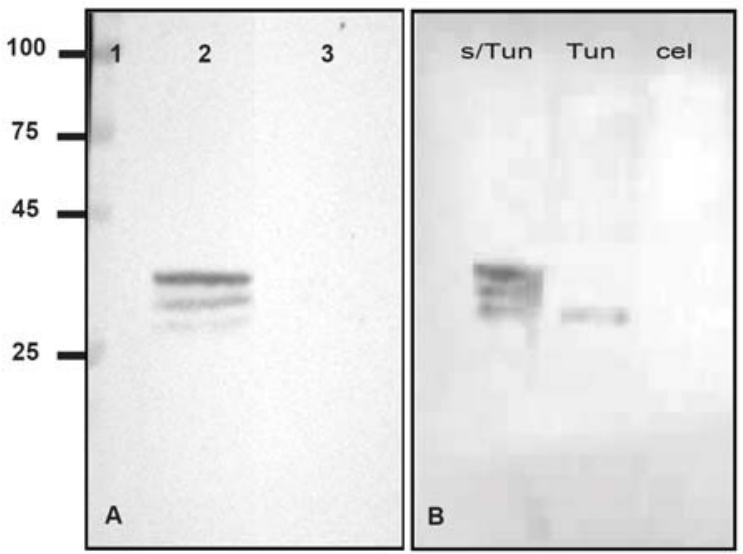

Fig. 3.12. A. Western Blot. Los tamaños del peso molecular figuran a la izquierda (en $\mathrm{kDa})$. Calle 1: marcadores de peso molecular. Calle 2: células infectadas con Acgp37EpapGV. Calle 3: células infectadas con AcZ. B. Western Blot. S/Tun: células infectadas con Acgp37EpapGV sin tunicamicina. Tun: células infectadas con Acgp37EpapGV sin tunicamicina. Cel. control no infectadascélulas.

La expresión en células de insecto infectadas con el recombinante Acgp37EpapGV y su reactividad inmunológica cruzada con anticuerpos contra fusolina confirmaron la identidad de GP37. La secuenciación del extremo amino de esta proteína y el tamaño del polipéptido expresado en presencia de tunicamicina coincidió con los datos predichos a partir de la secuencia nucleotídica y que, al menos, algunos de los sitios de glicosilación predichos son utilizados.

\section{Determinación de la presencia de GP37 en OB de EpapGV}

Se ha informado previamente que en algunos casos GP37 puede estar presente en el núcleo y ser incorporada en los cuerpos de oclusión (Vialard et al., 1990) o formar cristales debido el establecimiento de puentes disulfuro (Gauthier et al., 1995).

Los datos obtenidos en los ensayos sobre interacción entre AgMNPV y EpapGV presentados en el capítulo 2 sugieren la presencia de factores proteicos asociados a gránulos de EpapGV. En este contexto se podría especular que GP37 sería uno de estos factores. La aparición de inclusiones cristalinas constituidas por GP37 no es muy frecuente en infecciones producidas por NPVs (Gross et al., 1993; Li et al., 2000; Liu \& Carstens, 1996). En EPV, la fusolina cristaliza predominantemente en hospedadores del Orden Coleoptera (Gauthier et al., 1995) y hasta el momento no existen estudios de ningún tipo de GP37 en GVs.

Los cristales de fusolina, cuando son administrados oralmente para evaluar su efecto sobre MP, parecen resistir a los jugos intestinales manteniendo su estructura (Mitsuhashi et al., 2007). Lo observado en nuestro trabajo con microscopía electrónica de barrido, mostró la presencia de cuerpos esferoidales 18 hs después a 
la administración de mezclas conteniendo gránulos de EpapGV (Capítulo 2). Estos cuerpos no son OBs de EpapGV, ya que resultaron resistentes a la disolución en el medio alcalino del intestino medio de los lepidópteros.

La observación de gránulos de EpapGV expuestos durante diferentes períodos de tiempo a una solución alcalina de $\mathrm{Na}_{2} \mathrm{CO}_{3}$ mostró que en la mezcla de OBs existen partículas de 2 a $4 \mu \mathrm{m}$ resistentes a la disolución (Fig. 3.14).
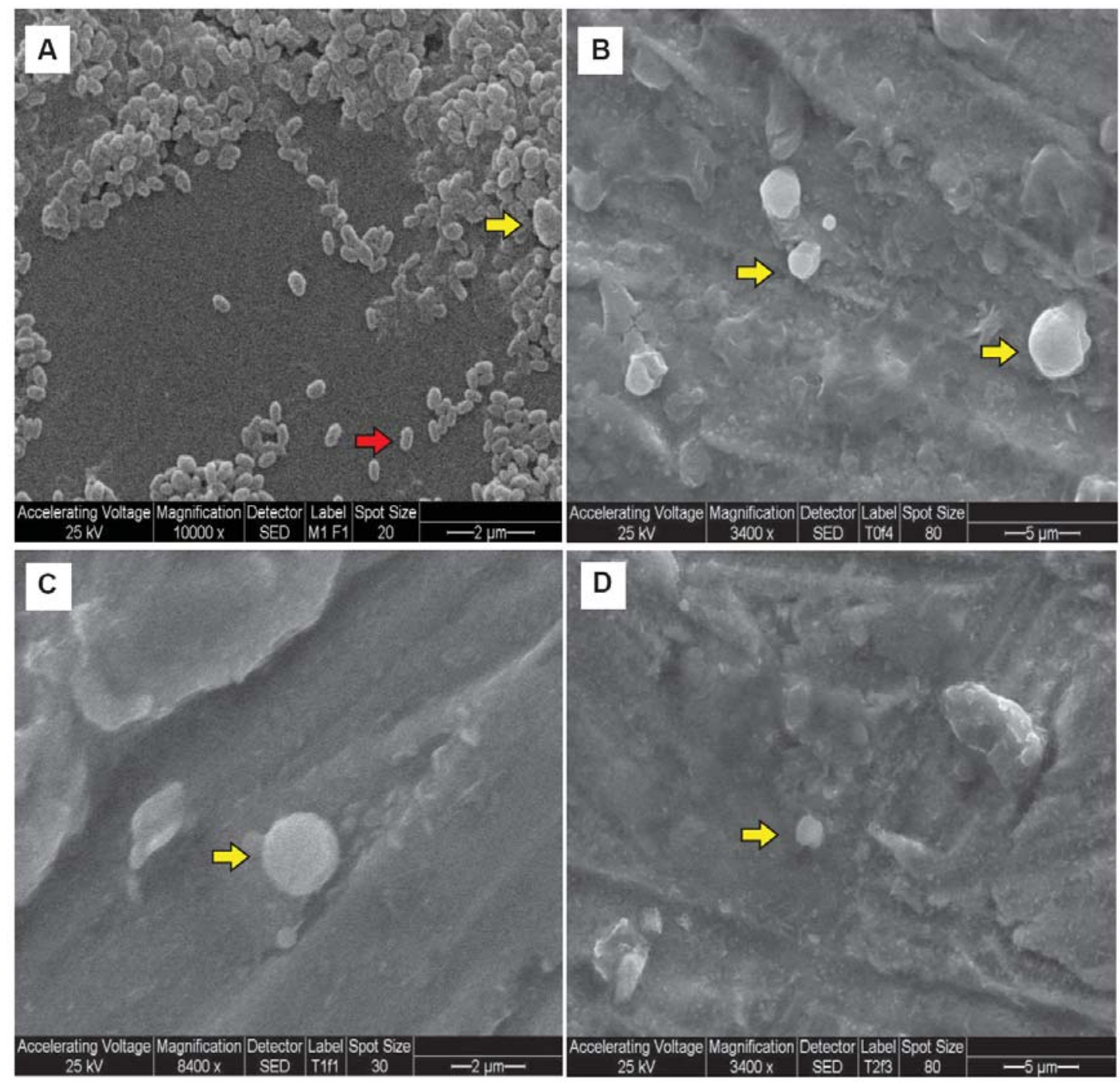

Fig. 3.14. Microscopía electrónica de barrido sobre suspensiones de gránulos de EpapGV disueltos por exposición durante distintos tiempos a una solución de $\mathrm{Na}_{2} \mathrm{CO}_{3}$. Con flecha roja se indica el $\mathrm{OB}$ y con flecha amarilla cuerpos proteicos. A: OBs de EpapGV sin disolver. B: gránulos expuestos a solución de carbonato la cual fue neutralizada con ácido clorhídrico a los 10 min. C: gránulos en solución de carbonato durante 6 horas. D: gránulos en solución de carbonato durante $18 \mathrm{hs}$. (barra de referencia en micrómetros en el ángulo inferior izquierdo). 
Como puede observarse, los OBs son inmediatamente disueltos ante el agregado de $\mathrm{Na}_{2} \mathrm{CO}_{3}$ (Fig. 3.14 B) y los cuerpos esferoidales de 2-4 $\mu \mathrm{m}$ siguen siendo visibles aún 18 hs posteriores al agregado de carbonato.

Con el fin de determinar si estos cuerpos podrían estar constituidos por GP37 se utilizaron los anticuerpos disponibles. La detección de GP37 en estos cuerpos mediante Western blot resultó negativa (datos no mostrados), quizás por una baja concentración de los mismos. El mismo ensayo se realizó sobre gránulos sin disolver y el resultado fue el mismo. Por tal motivo, no fue posible aún asociar los cristales observados por microscopía, con la proteína GP37. Se realizarán estos análisis con muestras de mayor tamaño. 


\section{Referencias}

Chen, C. J., Quentin, M. E., Brennan, L. A., Kukel, C. \& Thiem, S. M. (1998). Lymantria dispar nucleopolyhedrovirus hrf-1 expands the larval host range of Autographa californica nucleopolyhedrovirus. J Virol 72, 2526-2531.

Cheng, X., Krell, P. \& Arif, B. (2001). P34.8 (GP37) is not essential for baculovirus replication. J Gen Virol 82, 299-305.

Dall D, Luque T, O'Reilly D. Insect-virus relationships: sifting by informatics.Bioessays. 2001 Feb;23(2):184-93.

Dall, D., Sriskantha, A., Vera, A., Lai-Fook, J. \& Symonds, T. (1993). A gene encoding a highly expressed spindle body protein of Heliothis armigera entomopoxvirus. J Gen Virol 74 ( Pt 9), 1811-1818.

De Jong, J. G., Lauzon, H. A., Dominy, C., Poloumienko, A., Carstens, E. B., Arif, B. M. \& Krell, P. J. (2005). Analysis of the Choristoneura fumiferana nucleopolyhedrovirus genome. J Gen Virol 86, 929-943.

Fukatsu, T., Nikoh, N., Kawai, R. \& Koga, R. (2000). The secondary endosymbiotic bacterium of the pea aphid Acyrthosiphon pisum (Insecta: homoptera). Appl Environ Microbiol 66, 2748-2758.

Gauthier, L., Cousserans, F., Veyrunes, J. C. \& Bergoin, M. (1995). The Melolontha melolontha entomopoxvirus (MmEPV) fusolin is related to the fusolins of lepidopteran EPVs and to the 37K baculovirus glycoprotein. Virology 208, 427-436.

Greene, G. L., Leppla, N. C. \& Dickerson, W. A. (1976). Velvetbean caterpillar: a rearing procedure and artificial medium J Econ Entomol 69, 487-488.

Gross, C. H., Wolgamot, G. M., Russell, R. L., Pearson, M. N. \& Rohrmann, G. F. (1993). A 37-kilodalton glycoprotein from a baculovirus of Orgyia pseudotsugata is localized to 
cytoplasmic inclusion bodies. J Virol 67, 469-475.

Herniou, E. A. \& Jehle, J. A. (2007). Baculovirus phylogeny and evolution. Curr Drug Targets 8, 1043-1050.

Inceoglu, A. Bora, S. George Kamita, and Bruce D. Hammock (2006). Genetically modified baculoviruses: A historical overview and future outlook. Advances in Virus Research Vol 68, 323-360

Je, Y. H., Chang, J. H., Choi, J. Y., Roh, J. Y., Jin, B. R., O' Reilly, D. R. \& Kang, S. K. (2001). A defective viral genome maintained in Escherichia coli for the generation of baculovirus expression vectors. Biotechnol Lett 23, 575-582.

Laemmli, U. K. (1970). Cleavage of structural proteins during the assembly of the head of bacteriophage T4. Nature 227, 680-685.

Lai-Fook, J. \& Dall, D. J. (2000). Spindle bodies of Heliothis armigera entomopoxvirus develop in structures associated with host cell endoplasmic reticulum. $J$ Invertebr Pathol 75, 183-192.

Lauzon, H. A., Jamieson, P. B., Krell, P. J. \& Arif, B. M. (2005). Gene organization and sequencing of the Choristoneura fumiferana defective nucleopolyhedrovirus genome. J Gen Virol 86, 945-961.

Li, X., Barrett, J., Pang, A., Klose, R. J., Krell, P. J. \& Arif, B. M. (2000). Characterization of an overexpressed spindle protein during a baculovirus infection. Virology 268, 56-67.

Li, X., Barrett, J. W., Yuen, L. \& Arif, B. M. (1997). Cloning, sequencing and transcriptional analysis of the Choristoneura fumiferana entomopoxvirus spheroidin gene. Virus Res 47, 143-154.

Li, Z., Li, C., Yang, K., Wang, L., Yin, C., Gong, Y. \& Pang, Y. (2003). Characterization of a chitin-binding protein GP37 of Spodoptera litura multicapsid nucleopolyhedrovirus. Virus Res 96, 113-122.

Liu, J. J. \& Carstens, E. B. (1996). Identification, molecular cloning, and transcription 
analysis of the Choristoneura fumiferana nuclear polyhedrosis virus spindle-like protein gene. Virology 223, 396-400.

Lu, S. Y., Qi, Y. P. \& Ge, G. Q. (2002). Interaction of Heliothis armigera nuclear polyhedrosis viral capsid protein with its host actin. J Biochem Mol Biol 35, 562-567.

Maeda, S. (1989a). Expression of foreign genes in insects using baculovirus vectors. Annu Rev Entomol 34, 351-372.

Maeda, S. (1989b). Increased insecticidal effect by a recombinant baculovirus carrying a synthetic diuretic hormone gene. Biochem Biophys Res Commun 165, 1177-1183.

Mitsuhashi, W., Furuta, Y. \& Sato, M. (1998). The spindles of an entomopoxvirus of coleoptera (Anomala cuprea) strongly enhance the infectivity of a nucleopolyhedrovirus in lepidoptera. J Invertebr Pathol 71, 186-188.

Mitsuhashi, W., Kawakita, H., Murakami, R., Takemoto, Y., Saiki, T., Miyamoto, K. \& Wada, S. (2007). Spindles of an entomopoxvirus facilitate its infection of the host insect by disrupting the peritrophic membrane. J Virol 81, 4235-4243.

Parola, A. D., Manzan, M. A., Lozano, M. E., Ghiringhelli, P. D., Sciocco-Cap, A. \& Romanowski, V. (2002). Physical and genetic map of Epinotia aporema granulovirus genome. Virus Genes 25, 329-341.

Phanis, C. G., Miller, D. P., Cassar, S. C., Tristem, M., Thiem, S. M. \& O'Reilly, D. R. (1999). Identification and expression of two baculovirus gp37 genes. J Gen Virol 80 ( Pt 7), 1823-1831.

Takemoto, Y., Mitsuhashi, W., Murakami, R., Konishi, H. \& Miyamoto, K. (2008). The Nterminal region of an entomopoxvirus fusolin is essential for the enhancement of peroral infection, whereas the C-terminal region is eliminated in digestive juice. $J$ Virol 82, 12406-12415.

Techkarnjanaruk, S. \& Goodman, A. E. (1999). Multiple genes involved in chitin degradation from the marine bacterium Pseudoalteromonas sp. strain S91. Microbiology $145(\mathrm{Pt}$ 
4), 925-934.

Thompson, J. D., Gibson, T. J., Plewniak, F., Jeanmougin, F. \& Higgins, D. G. (1997). The CLUSTAL_X windows interface: flexible strategies for multiple sequence alignment aided by quality analysis tools. Nucleic Acids Res 25 , 4876-4882.

Tsujibo, H., Orikoshi, H., Baba, N., Miyahara, M., Miyamoto, K., Yasuda, M. \& Inamori, Y. (2002). Identification and characterization of the gene cluster involved in chitin degradation in a marine bacterium, Alteromonas sp. strain 0-7. Appl Environ Microbiol 68, 263-270.

Vaaje-Kolstad, G., Horn, S. J., van Aalten, D. M., Synstad, B. \& Eijsink, V. G. (2005). The non-catalytic chitin-binding protein CBP21 from Serratia marcescens is essential for chitin degradation. J Biol Chem 280, 28492-28497.

Vaughn, J. L., Goodwin, R. H., Tompkins, G. J. \& McCawley, P. (1977). The establishment of two cell lines from the insect Spodoptera frugiperda (Lepidoptera; Noctuidae). In Vitro 13, 213-217.

Vialard, J. E., Yuen, L. \& Richardson, C. D. (1990). Identification and characterization of a baculovirus occlusion body glycoprotein which resembles spheroidin, an entomopoxvirus protein. J Virol 64, 5804-5811.

Wang, H., Wu, D., Deng, F., Peng, H., Chen, X., Lauzon, H., Arif, B. M., Jehle, J. A. \& Hu, Z. (2004a). Characterization and phylogenetic analysis of the chitinase gene from the Helicoverpa armigera single nucleocapsid nucleopolyhedrovirus. Virus Res 100, 179189.

Wang, P., Li, G. \& Granados, R. R. (2004b). Identification of two new peritrophic membrane proteins from larval Trichoplusia ni: structural characteristics and their functions in the protease rich insect gut. Insect Biochem Mol Biol 34, 215-227.

Watanabe, T., Kimura, K., Sumiya, T., Nikaidou, N., Suzuki, K., Suzuki, M., Taiyoji, M., Ferrer, S. \& Regue, M. (1997). Genetic analysis of the chitinase system of Serratia 
marcescens 2170. J Bacteriol 179, 7111-7117.

Wickham, T. J., Davis, T., Granados, R. R., Shuler, M. L. \& Wood, H. A. (1992). Screening of insect cell lines for the production of recombinant proteins and infectious virus in the baculovirus expression system. Biotechnol Prog 8, 391-396.

Wijonarko, A. \& Hukuhara, T. (1998). Detection of a virus enhancing factor in the spheroid, spindle, and virion of an entomopoxvirus. $J$ Invertebr Pathol 72, 82-86.

Zuidema, D., Klinge-Roode, E. C., van Lent, J. W. \& Vlak, J. M. (1989). Construction and analysis of an Autographa californica nuclear polyhedrosis virus mutant lacking the polyhedral envelope. Virology 173, 98-108. 
Capítulo 4

Caracterización de la quitinasa de EpapGV 


\section{Indice temático}

$\begin{array}{ll}\text { Introducción } & 91\end{array}$

$\begin{array}{ll}\text { Materiales y métodos } & 93\end{array}$

$\begin{array}{ll}\text { Resultados y discusión } & 98\end{array}$

$\begin{array}{ll}\text { Análisis de la secuencia } & 98\end{array}$

Expresión y análisis de CHIA de EpapGV 100

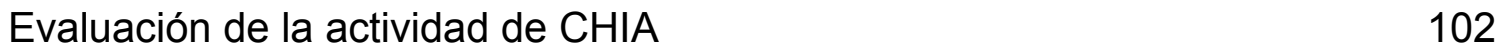

Organización genómica de las regiones flanqueantes de chiA de EpapGV y análisis filogenético

Referencias 


\section{Introducción}

La quitina es un polímero lineal constituido por monómeros de $(1,4)-\mathrm{N}$ acetilglucosamina (GlcNAc). Es uno de los componentes principales de las paredes celulares de los hongos, animales como anélidos y cnidarios y también está presente en el resistente exoesqueleto de los artrópodos (incluidos arácnidos, crustáceos e insectos). En estos últimos cumple funciones estructurales y se la encuentra constituyendo la cutícula adyacente a la epidermis y la tráquea. También, como se mencionó en el capítulo anterior, es un componente principal de la membrana peritrófica (MP) intestinal. Evolutivamente, una gran diversidad de organismos desarrolló la capacidad de metabolizar la quitina mediante catalizadores biológicos con diferentes propósitos. El conjunto de enzimas que participan en las rutas degradativas de la quitina son denominadas quitinasas. Las mismas se aislaron de los artrópodos, virus, bacterias, hongos, plantas, nematodos y varios vertebrados (Fukamizo, 2000).

En los insectos, las quitinasas desempeñan un papel importante en el metabolismo de la quitina, que es fundamental para el crecimiento de los insectos y la morfogénesis (Merzendorfer \& Zimoch, 2003). Las cutículas de los insectos forman un exoesqueleto que exhibe sólo una capacidad limitada para mantener el ritmo de crecimiento del cuerpo, porque es una estructura rígida debido a la presencia de quitina y de proteínas esclerotizadas. Para permitir el crecimiento y el desarrollo, los insectos se ven periódicamente obligados a reemplazar su vieja cutícula con una nueva y más flexible durante una muda (ecdisis). El fluido sintetizado durante este proceso contiene proteasas y quitinasas, que digieren y reciclan los principales componentes de la cutícula al mudar (Merzendorfer \& Zimoch, 2003; Reynolds, 1996).

Las quitinasas se clasifican en dos diferentes familias, 18 y 19 de las glicósidohidrolasas, sobre la base de su similitud aminoacídica y sus dominios catalíticos (Davies \& Henrissat, 1995; Henrissat \& Romeu, 1995). La Familia 18 incluye a las quitinasas de bacterias, hongos, virus, animales y las de algunas plantas (Clases III y V); en la familia 19 se incluyen a las de las plantas (clases I, II y IV). Las 
quitinasas de ambas familias no comparten similitud a nivel aminoacídico y las estructuras tridimensionales son diferentes por lo que se supone que evolutivamente tienen orígenes distintos (Henrissat, 1991)

Funcionalmente, las quitinasas se pueden clasificar como endo y exoquitinasas. Las endoquitinasas clivan la quitina al azar en sitios internos, liberando oligómeros solubles de GlcNAc (Sahai, 1993). Las exoquitinasas catalizan la liberación de dímeros de GlcNAc (N, N-diacetilquitobiosas) desde los extremos de las microfibrillas de la quitina para posteriormente generar monómeros de GIcNAc (Harman, 1993; Cohen-Kupiec \& Chet, 1998). Las quitinasas maduras se caracterizan a nivel proteico por poseer un dominio de unión a quitina, un dominio catalítico y una región bisagra que une ambos (Shinshi et al., 1990).

La familia 18 incluye a quitinasas presentes en bacterias, diversos eucariotas y virus, incluyendo a las codificadas por los baculovirus (Hawtin et al., 1995; Henrissat, 1999).

Hasta el presente, se han encontrado genes de quitinasa en la mayoría de los genomas baculovirales (Tabla 4.1). En AcMNPV, el gen que codifica para la síntesis de CHIA es expresado en la etapa tardía de la replicación del virus y posee actividad tanto endo como exoquitinasa (Hawtin et al., 1995; Rao et al., 2004). Sin embargo, dentro de los baculovirus existen variaciones y así, por ejemplo, la CHIA de Epiphyas postvittana nucleopoliedrovirus (EppoNPV) es una exoquitinasa con una baja actividad endoquitinasa (Young et al., 2005).

La función principal de las quitinasas encontradas en los baculovirus es intervenir en la licuefacción de los cadáveres de larvas infectadas (Fig. 4.1). La degradación de la cutícula de los insectos facilita la dispersión de los cuerpos de oclusion (OB) virales en el medio ambiente. Un gen denominado catepsina ( $V$-Cath), hallado en el genoma de los baculovirus contribuye también al proceso de licuefacción de las larvas infectadas (Ohkawa et al., 1994; Rawlings et al., 1992; Slack et al., 1995).

El producto del gen $V$-cath cumple la función de degradar las proteínas cuticulares y facilitar el acceso de CHIA a la quitina (Hawtin et al., 1997). En la infección de células con virus en los cuales chiA fue delecionado, se inhibe la síntesis de los precursores de la catepsina viral por lo que se postula que CHIA también puede servir de chaperona molecular para el plegado de $\mathrm{V}-\mathrm{CATH}$ en el retículo endoplasmático (Hom \& Volkman, 2000). 


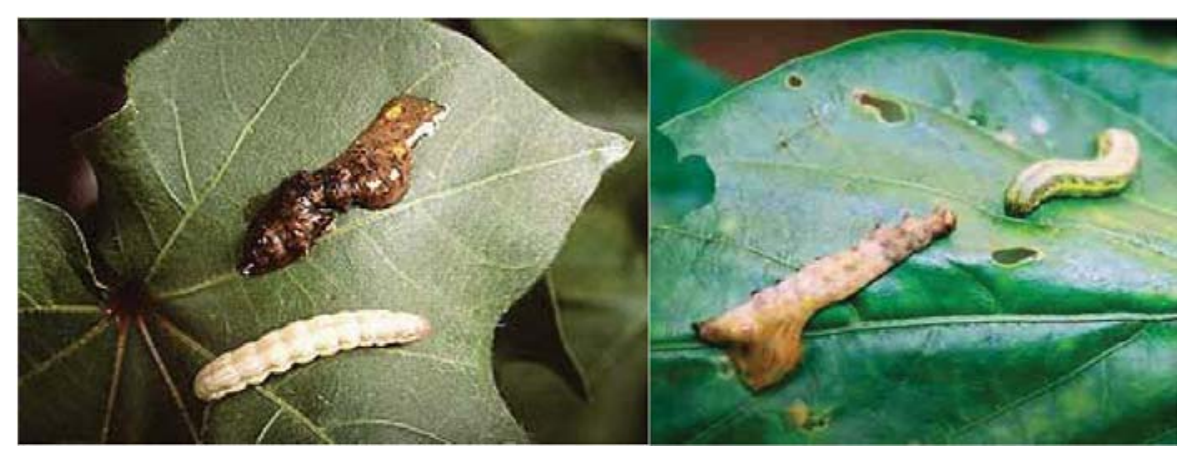

Fig. 4.1. Larvas infectadas por NPV en un estado temprano de infección (coloración blanquecina por la acumulación de OBs) y muertas. La ruptura del tegumento se debe a la licuefacción por acción de genes como quitinasa y catepsina.

La quitinasa de AcMNPV expresada en Escherichia coli fue capaz de perforar la MP de larvas de Bombyx mori, provocando un $100 \%$ de mortalidad cuando las mismas fueron alimentadas con la enzima en una concentración de $1 \mathrm{mg} / \mathrm{g}$ de peso corporal de las larvas. También se observó una reducción del crecimiento de las larvas cuando se alimentaron con dosis subletales de quitinasa ( $0,56 \mathrm{mg} / \mathrm{g}$ de lípidos) (Rao et al., 2004). Estas observaciones demuestran el potencial que posee la quitinasa como herramienta en el control biológico. Hasta el momento, no existen estudios que demuestren la actividad de CHIA baculoviral in vivo en las primeras etapas del ciclo infectivo, por tal motivo se iniciaron estudios tendientes a caracterizar la quitinasa presente en el genoma de EpapGV y determinar si puede tener un rol relevante en las primeras etapas de la infección viral. 


\section{Materiales y métodos}

Insectos. Las larvas de Epinotia aporema fueron empleadas para la multiplicación de virus y bioensayos, fueron provistas por el insectario del IMYZA-INTA, Castelar. La cría de los insectos se realizó bajo condiciones controladas de temperatura (26 \pm $\left.1^{\circ} \mathrm{C}\right)$, humedad relativa $(50-70 \%)$ y fotoperíodo $(14: 10 \mathrm{~L} / \mathrm{O})$ y fueron mantenidos en dieta artificial (Greene et al., 1976)

Células de insectos. Células de Trichoplusia ni (HighFive) (Wickham et al., 1992) y Spodoptera frugiperda SF9 (Vaughn et al., 1977) fueron mantenidas en medio TC100 y suplementadas con $10 \%$ de suero fetal Bovino (BIOSER).

Virus. EpapGV fue multiplicado en larvas de cuarto estadio de E. aporema. La propagación se realizó por contaminación superficial de la dieta (sin formaldehído) con cuerpos de inclusión $\left(1 \times 10^{3} \mathrm{OBs} / \mathrm{mm}^{2}\right)$. Las larvas fueron mantenidas bajo condiciones controladas de temperatura $\left(26 \pm 1^{\circ} \mathrm{C}\right)$ y humedad $(50 \%)$ hasta el momento de recolección del material infectado.

Extracción de DNA de EpapGV. Las larvas recolectadas fueron maceradas en baño hielo agua. Esta mezcla se filtró a través de una gasa colocada en un tubo eppendorf de $0,5 \mathrm{ml}$ perforado en su base. El filtrado fue tratado con $\mathrm{Na}_{2} \mathrm{CO}_{3} \mathrm{a}$ concentración final de $0,1 \mathrm{M}$ durante $30 \mathrm{~min}$, se neutralizó la solución mediante agregado de Tris-HCl (pH 6,2). Las muestras fueron hervidas por 5 min y se utilizó 1 $\mu \mathrm{l}$ de esta solución para la reacción de PCR.

Extracción de cuerpos de oclusión a partir de larvas infectadas con EpapGV. Las larvas infectadas fueron recolectadas y maceradas con la ayuda de un mortero, se agregó agua para ayudar a la homogeneización, esta mezcla se incubó a temperatura ambiente una semana. Posteriormente, se filtró la mezcla a través de gasa, se midió el volumen y se agregó SDS a concentración final de $0,1 \%$. Se centrifugó 2 min a 2000 rpm en rotor SS34 (Sorvall) para eliminar todos los restos celulares. Los OBs se purificaron por ultracentrifugación en gradientes de densidad de sacarosa (35-60\% p/p) a 20000 rpm en rotor Beckman SW 28 y posteriormente se extrajo la fracción correspondiente a los gránulos. La misma se diluyó 1:3 en 
agua destilada, se centrifugó $30 \mathrm{~min}$ a $10000 \mathrm{rpm}$ en rotor SS34 (Sorvall) y se resuspendió en agua para eliminar los restos de sacarosa. El pellet final fue resuspendido en agua.

Secuenciación y amplificación de chiA de EpapGV. Al momento de iniciar este trabajo, solo se conocía la secuencia parcial de chiA de EpapGV (Parola et al., 2002). Por este motivo, en base a la secuencia disponible se diseño un primer (dato no mostrado) que permitió obtener la secuencia completa de este ORF. Posteriormente, se diseñaron primers con sitios de restricción (señalados entre paréntesis): chiA-EpapGV (Kpnl) 5'-TGGTACCGTATGAAACTAGCAATTGTGTC-3' y chiA-EpapGV (Xhol) 5'-CGACGCGTCGTATGAAACTAGCAATTG-3', que permitieron la amplificación completa del ORF para su posterior clonado.

Análisis bioinformático y filogenético. La secuencia teórica aminoacídica de CHIA de EpapGV fue utilizada para la búsqueda de patrones y motivos característicos en InterProscan. También se comparó con secuencias obtenidas por BLASTP en el EMBL/GenBank. Las mismas se alinearon mediante el uso del programa CLUSTAL X (Thompson et al., 1997) con los siguientes parámetros: pairwise alignments; slow, gap opening 10, gap extension 0 \pm 1 , matrix BLOSUM, 30; multiple alignments; gap opening 10, gap extension $0 \pm 05$. En el alineamiento final se utilizó la secuencia completa de cada una de las proteínas utilizadas. El análisis filogenético se realizó con el método del vecino más cercano (Neighbor-joining ,NJ) usando el conjunto de programas de MEGA 3.1 (D. L. Swofford). Los valores de bootstrap en NJ se obtuvieron después de 500 replicaciones.

Orden y presencia de genes chiA-gp37 en genomas baculovirales. En el EMBL/GenBank se realizó la búsqueda de genomas completos baculovirales para el análisis de la presencia/ausencia de gp37 y chiA, así también como la posición relativa que ocupan en los mismos. Debido a la existencia de homólogos a estos dos genes (cbps-chiA) en bacterias, también se analizó la disposición de estos genes en los genomas bacterianos disponibles.

Expresión de chiA en un sistema eucariota. El producto correspondiente a chiA de EpapGV obtenido por amplificación, fue clonado inicialmente en el vector pGEM$\mathrm{T}$ (Promega) y luego digerido con las enzimas Kpnl y Xhol (Promega) para su 
clonado en el vector pBacPack 8 (Invitrogen) digerido con el mismo par de enzimas (Fig. 4.2).

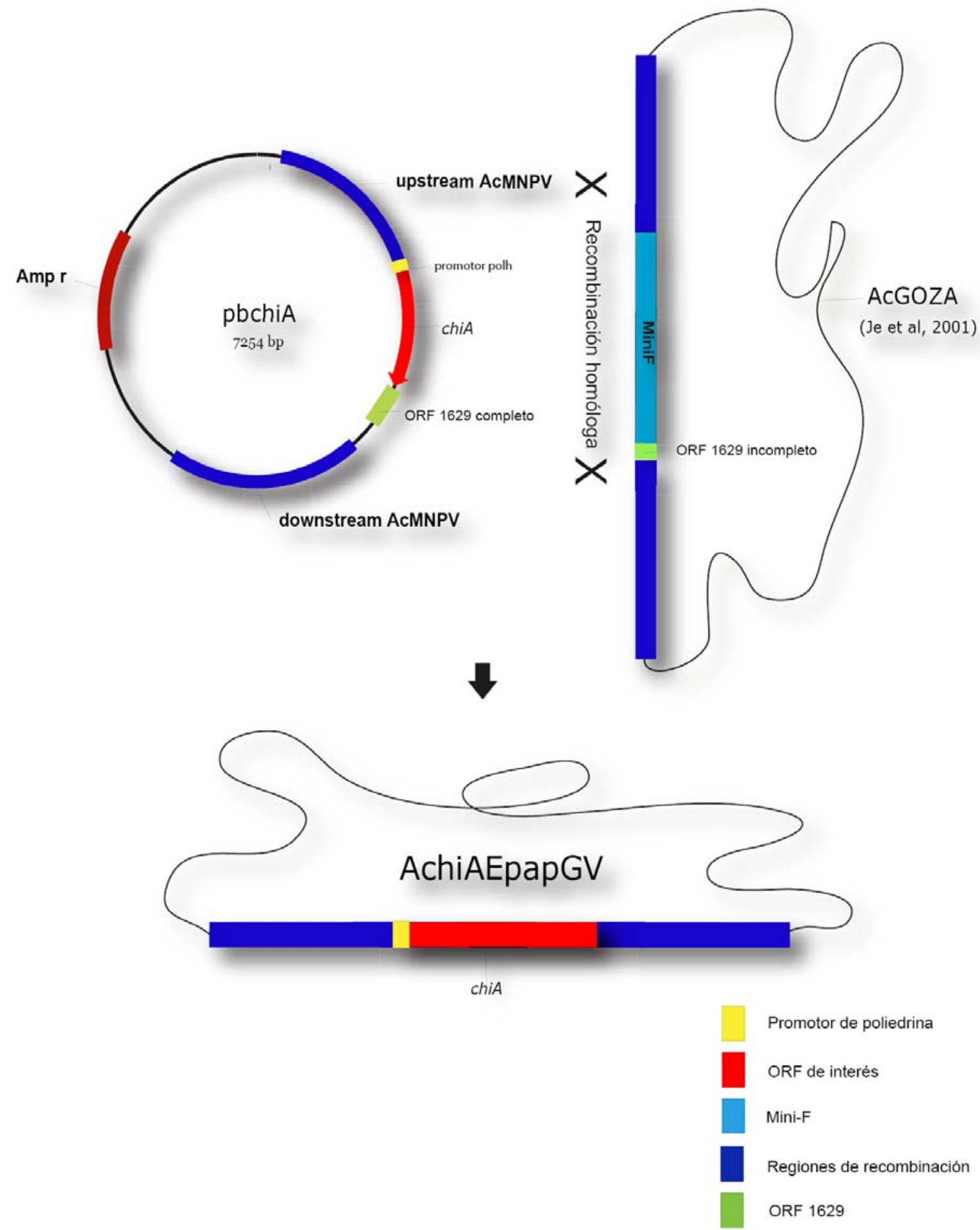

Fig. 4.2. Metodología utilizada para la obtención del recombinante AchiAEpapGV. Cotransfección en células de insectos del plásmido de transferencia (pbchiA) con DNA del bácmido de AcMNPV (AcGOZA) 
Una vez ligados el inserto y el vector, se transformaron células $\mathrm{DH} 5 \mathrm{a}$ electrocompetentes. Las colonias se seleccionaron mediante la utilización de ampicilina, luego fueron examinadas por colony PCR usando los primers que amplificaron inicialmente el ORF y mediante los primers bac1 (5'AACCATCTCGCAAATAAATA-'3) y bac2 (5'-TTGCGTGTCTTAGATCGGAA-'3) cuyos sitios complementarios en el vector corresponden a regiones externas y flanqueantes a la de la inserción del ORF. El plásmido obtenido (denominado pbchiA) fue purificado y utilizado para cotransfectar junto a DNA del bácmido AcGOZA (sistema descrito en el capítulo anterior), células SF-9 sembradas en placas de $35 \mathrm{~mm}\left(0.5 \times 10^{6}\right.$ células $)$. El reactivo de transfección Cellfectin (Invitrogen) fue utilizado siguiendo las especificaciones y recomendaciones del fabricante. Las células fueron mantenidas a $27^{\circ} \mathrm{C}$ por 4 horas con la mezcla lípidosDNA y luego la misma fue reemplazada con medio TC-100 suplementado con $10 \%$ de suero fetal bovino. La incubación a $27^{\circ} \mathrm{C}$ se extendió hasta el momento de observar la presencia de células con poliedros. El sobrenadante conteniendo BVs del recombinante AchiAEpapGV, se utilizó para reinfectar células Sf9. Posteriormente, se realizó el segundo pasaje sobre células de Trichoplusia ni (HighFive).

Análisis mediante SDS-PAGE y Western Blot. Las células infectadas con el recombinante AchiAEpapGV fueron levantadas 72 hs post-infección, lavadas dos veces con buffer PBS, centrifugadas y resuspendidas en SDS-PAGE sample buffer. Posteriormente, las muestras fueron separadas por electroforesis en gel de poliacrilamida al 10\% (SDS-PAGE) (Laemmli, 1970), usando el equipo Mini-protean II (Bio-Rad). Las proteínas se transfirieron a una membrana de PVDF (ImmobilonPsq; Millipore, Bedford, MA) usando un aparato Semidry Transblot (Bio-Rad).La transferencia se realizó a $15 \mathrm{~V}$ por $30 \mathrm{~min}$. Posteriormente, las membranas se incubaron en una solución de bloqueo (PBS conteniendo $5 \%$ de leche descremada) por $1 \mathrm{~h}$ a temperatura ambiente. Luego, las mismas fueron incubadas durante $1 \mathrm{~h} \mathrm{a}$ temperatura ambiente con una dilución 1:1.000 del anticuerpo anti-CHIA y se lavó tres veces con PBS que contenía 0,05\% de Tween 20 (Daimon et al., 2005). A continuación, la membrana fue incubada $1 \mathrm{~h}$ con una dilución 1:5.000 de anticuerpos anti-lgG de conejo conjugados a HRP (Santa Cruz Biotechnology). Posteriormente se lavó en PBS $+0,05 \%$ de Tween 20 y se reveló con DAB (Sigma) 
y $\mathrm{H}_{2} \mathrm{O}_{2}$. Como controles se utilizaron células HighFive sin infectar y células infectadas con un recombinante de AcGOZA generado para expresar proteínas del virus Junín ( $Z$ y GPC) no relacionadas con los baculovirus.

Detección de CHIA en cuerpos de oclusión. Soluciones de $20 \mu \mathrm{l}$ conteniendo $2 \times 10^{5} \mathrm{OB} / \mathrm{ml}$ de los virus AchiAEpapGV y wt AcMNPV fueron mezcladas de manera independiente con SDS-PAGE sample buffer y sus proteínas separadas mediante SDS-PAGE. Posteriormente se transfirieron a una membrana de PVDF y se analizaron mediante Western Blot (siguiendo el protocolo descrito anteriormente). Como control positivo se utilizaron extractos de células HighFive infectadas con el virus AcchiAEpapGV.

Ensayos de actividad enzimática con quitina marcada. Se evaluó el uso del sustrato cromogénico chitin-azure (Sigma) y la quitinasa comercial de Streptomyces griseus (SIGMA) en el medio de cultivo celular (TC-100) suplementado con suero fetal bovino. La actividad de la enzima se evidencia por la liberación del cromógeno que es cuantificado en espectofotómetro a una longitud de onda de $560 \mathrm{~nm}$. Sobrenadantes de células de Trichoplusia ni $\left(2 \times 10^{6}\right)$ fueron recolectados $(500 \mu \mathrm{l})$ y mezclados $0,5 \mathrm{mg}$ de quitina-azul (SIGMA) y la quitinasa de Streptomyces griseus. Como control negativo solo se utilizo $\mathrm{SN}$ y quitina marcada. Las mezclas se incubaron a $27^{\circ} \mathrm{C}$ durante $96 \mathrm{~h}$ y posteriormente se centrifugó a $14000 \mathrm{rpm}$ para precipitar la quitina marcada. Los sobrenadantes fueron utilizados para la medición de la absorbancia a $560 \mathrm{~nm}$ en espectrofotómetro. Una unidad de enzima es la cantidad de enzima que produce un aumento de 0,01 en la absorbancia.

Actividad enzimática de CHIA a diferentes temperaturas. Se infectaron células de Trichoplusia ni $\left(2 \times 10^{6}\right)$ con el virus recombinante AchiAEpapGV (10 m.o.i.), utilizándose el virus salvaje AcMNPV (10 m.o.i.) como control negativo. Al observarse un elevado porcentaje de células infectadas y lisadas (cerca del 80\%) los sobrenadantes fueron recolectados. Luego de una centrifugacíon de $5 \mathrm{~min}$ a $10000 \mathrm{rpm}$ para precipitar restos celulares, un mililitro del SN fue mezclado con $1 \mathrm{ml}$ de sodio $0,2 \mathrm{M}$ ( $\mathrm{pH}$ 6.5) y $5 \mathrm{mg}$ de quitina-azul (SIGMA) .La mezcla se incubó a diferentes temperaturas $\left(17,27,37\right.$ y $\left.47^{\circ} \mathrm{C}\right)$ durante 5 días y luego se centrifugaron a $14000 \mathrm{rpm}$. Los sobrenadantes fueron utilizados para la medición de la absorbancia a $560 \mathrm{~nm}$ en espectrofotómetro, considerando que una unidad de enzima es la cantidad de enzima que produce un aumento de 0,01 en la 
absorbancia. Como control positivo se usó quitinasa comercial de Streptomyces griseus (SIGMA).

Evaluación de la actividad enzimática de CHIA a diferentes pH. Células de Trichoplusia ni $\left(2 \times 10^{6}\right)$ fueron infectadas con el virus recombinante AchiAEpapGV (10 m.o.i.), utilizándose el virus salvaje AcMNPV (10 m.o.i.) como control negativo. Al observarse un elevado porcentaje de células infectadas y lisadas (cerca del $80 \%$ ) los sobrenadantes fueron recolectados. Luego de una centrifugacíon de $5 \mathrm{~min}$ a $10000 \mathrm{rpm}$ para precipitar restos celulares, $500 \mu \mathrm{l}$ de la muestra fueron mezclados con $500 \mu$ de medio TC100 a diferentes pH (desde pH 3 a pH 11) y 5 mg de quitinaazul (SIGMA). Las mezclas se incubaron a $27^{\circ} \mathrm{C}$ durante 5 días y posteriormente se centrifugaron a $14.000 \mathrm{rpm}$. Los sobrenadantes fueron utilizados para la medición de la absorbancia a $560 \mathrm{~nm}$, en espectrofotómetro. Se considera que la actividad de una unidad de enzima produce un aumento de 0,01 en la absorbancia. 


\section{Resultados y discusión}

\section{Análisis de la secuencia}

El análisis de la secuencia nucleotídica obtenida a partir del genoma de EpapGV determinó que el ORF posee una longitud de 1.713 pares de bases y que se encuentra bajo regulación de un promotor tardío. En base a la secuencia obtenida se diseñaron primers específicos que permitieron amplificar el ORF utilizando como molde tanto el DNA de EpapGV como diferentes clones conteniendo fragmentos genómicos que incluyen a chiA (Fig. 4.3). La comparación con otras secuencias obtenidas del GenBank mediante el algoritmo Blastp, identificó a las quitinasas (chiA) de Cydia pomonella granulovirus (CpGV) y de Agrotis segetum granulovirus (AgseGV) como las secuencias con mayor porcentaje de identidad aminoacídica $(61 \%)$. Entre otros genes con alta homología, podemos hallar secuencias de CHIA de numerosos Granulovirus, Nucleopolyhedrovirus y de bacterias, como Serratia marcescens.

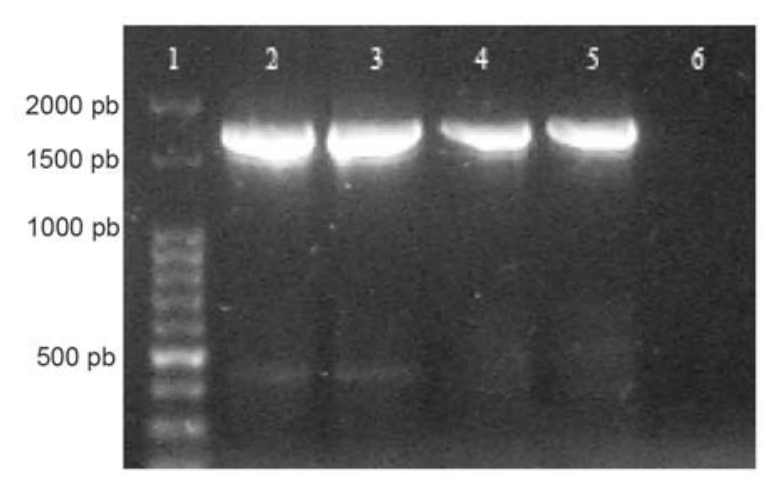

Fig. 4.3. La amplificación del ORF con los primers diseñados a partir de genoma viral y de diferentes clones conteniendo el fragmento con chiA. Calle 1: marcador de peso molecular, calle 2: DNA EpapGV, calle 3: Clon J (genoteca HindIII EpapGV), Calle 4: Clon B (genoteca Bglll EpapGV), calle 5: Clon E (genoteca BamHI EpapGV), calle 6: control negativo.

La traducción teórica de la secuencia nucleotídica obtenida indica que codifica para una proteína de 568 aminoácidos cuyo peso molecular fue estimado en 63 kDa. Del primer análisis de la secuencia aminoacídica se deduce que no posee el motivo KDEL de retención en retículo endoplásmico, tal como fue descrito anteriormente para la secuencia aminoacídica de CHIA de CpGV (Daimon et al., 2007). Según la base de datos utilizada (InterProScan) la enzima se clasifica como una O- 
glicosilhidrolasa. La misma se incluye en un amplio grupo de enzimas que son capaces de hidrolizar enlaces glucosídicos entre dos o más carbohidratos, o entre un carbohidrato y otro tipo de compuestos. El sistema de clasificación de las glicosilhidrolasas está basado sobre la similitud de secuencia y ha dado lugar a la definición de 85 familias (Henrissat \& Romeu, 1995).

El dominio catalítico hallado en CHIA (ubicado entre los aa 115 y 522) se clasifica como integrante de la familia 18. Dentro de este dominio, el sitio activo para CHIA de EpapGV está ubicado entre los aminoácidos 301-309 (FDGVDIDWE). Cercano al extremo aminoterminal (ubicado entre el aa 14 al 150) se halló un dominio denominado $\mathrm{N}$-terminal, este se encuentra en una serie de quitinasas bacterianas y virales (Fig.4.4 y 4.5). Su función no es conocida, pero se supone que pueden intervenir en la interacción con el sustrato de la enzima, la quitina. El mismo está separado por una región bisagra del dominio catalítico; esta región es probablemente móvil, permitiendo al dominio $\mathrm{N}$-terminal tener diferentes posiciones relativas en solución (Perrakis et al., 1994). La existencia característica del péptido señal se encontró entre las posiciones aminoacídicas 1 y 15 (Fig.4.4)

NH2- $A$

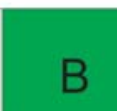
C 1 $-\mathrm{COOH}$

Fig: 4.4. Representación esquemática de la quitinasa de los baculovirus. A: péptido señal, B: dominio $\mathrm{N}$-terminal, $\mathrm{C}$ : domino catalítico que incluye el sitio activo (1). Entre el dominio B y el $\mathrm{C}$ se encuentra la denominada región bisagra.

La secuencia nucleotídica de chiA de EpapGV estudiada y analizada en este capítulo presenta un promotor tardío acorde a su participación en los estadios finales del proceso infectivo (Hawtin et al., 1995). Este gen codifica para la síntesis de una enzima (CHIA) cuyo análisis determinó que posee las regiones y dominios característicos de la familia 18 de las glicósido-hidrolasas. Entre estos se puede mencionar al péptido señal, el dominio de unión a quitina y el sitio catalítico (Henrissat, 1999).

La pérdida del motivo proteico KDEL de retención en retículo endoplásmico, es una particularidad que comparte con la CHIA de CpGV (Daimon et al., 2007). La 
utilización de anticuerpos anti-CHIA permitió por un lado, confirmar la identidad proteica de la CHIA de EpapGV clonada y expresada en un sistema eucariota, y por otro, confirmó su presencia en el sobrenadante celular acorde con la pérdida del motivo KDEL.

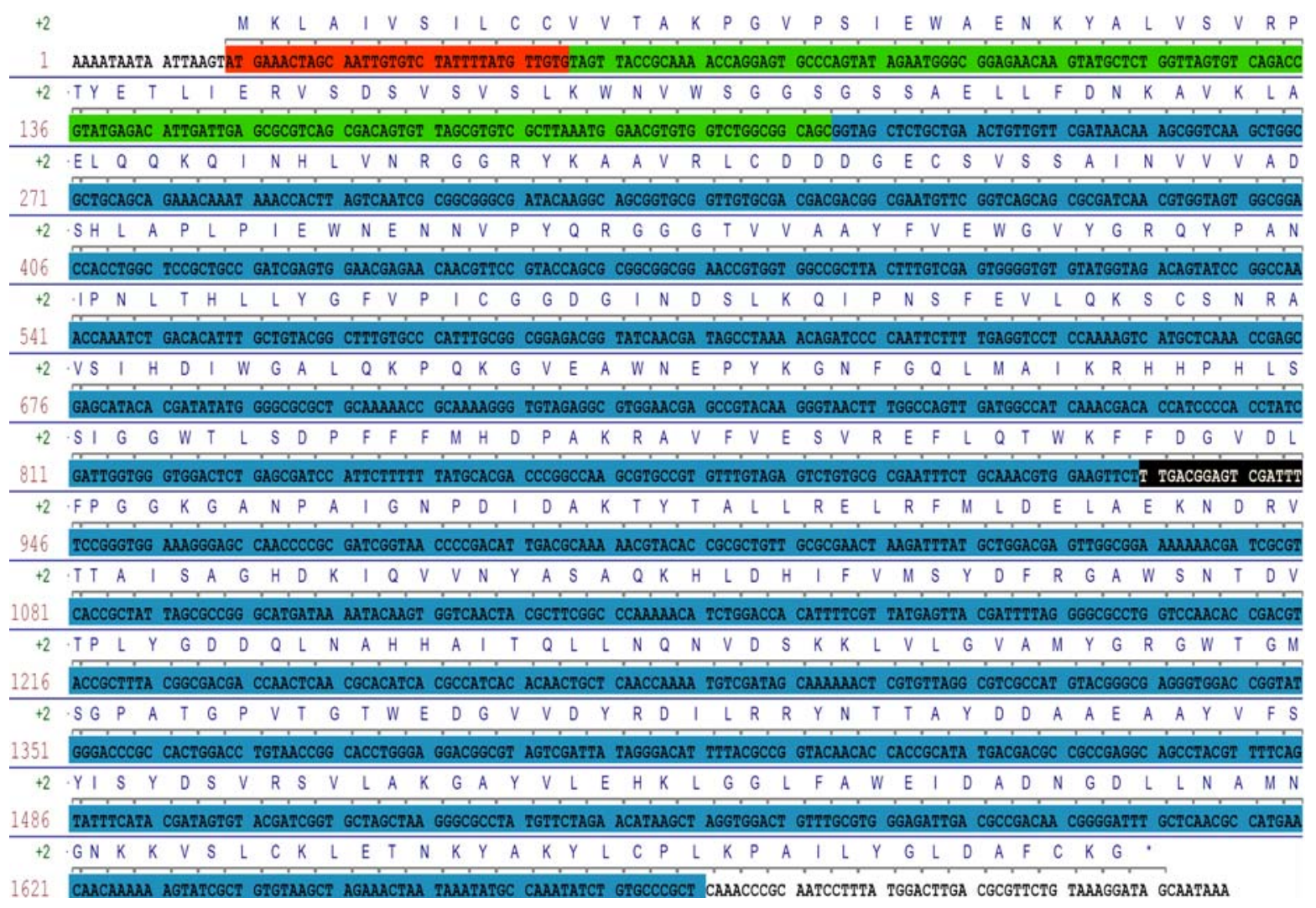

Péptido señal

Dominio N-Terminal

Dominio catalítico

Sitio activo

Fig. 4.5. Secuencia nucleotídica y aminoacídica de chiA de EpapGV. Los distintos sitios y dominios relevantes se encuentran subrayados.

\section{Expresión y análisis de CHIA de EpapGV}

El recombinante obtenido de AcMNPV conteniendo el ORF chiA de EpapGV (AchiAEpapGV), se utilizó para infectar células HighFive y las proteínas obtenidas de las mismas se analizaron mediante SDSPAGE y tinción con Coomassie brilliant blue. En comparación con los controles utilizados se observó la presencia de una 
banda de aproximadamente $63 \mathrm{kDa}$ acorde con el peso molecular esperado para CHIA de EpapGV (Fig. 4.6 A)

Con el objetivo de revelar la identidad de la proteína expresada en células de insecto infectadas con el recombinante AchiAEpapGV, se utilizaron anticuerpos anti-CHIA (gentilmente enviados por la Dra. Hualin Wang, Wuhan Institute of Virology, China).

Mediante la técnica de Western Blot se pudo confirmar la presencia de CHIA de EpapGV en el extracto proteico celular (Fig. 4.6 B 1-2). Dada la característica en la secuencia aminoacídica de no poseer el motivo de retención en retículo (KDEL), se evaluó la presencia de CHIA en el sobrenadante (SN) de células infectadas con el recombinante AchiAEpapGV. Los resultados mostraron que CHIA es detectada en el SN en etapas previas a la lisis celular, estando esto en concordancia con los motivos descriptos en la secuencia proteica (Fig.4.6 B 3-4).

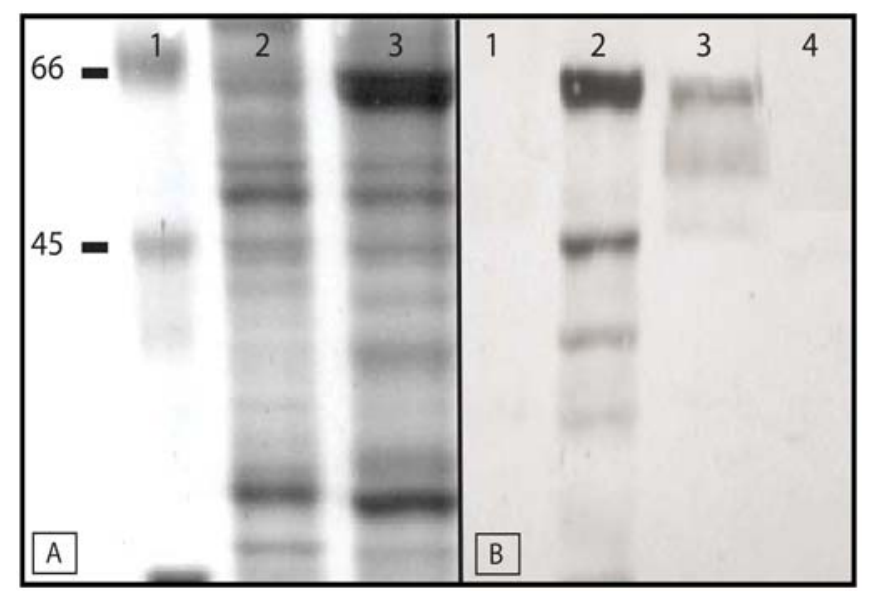

Fig. 4.6. A: SDS-PAGE de extractos celulares teñidos con Coomasie blue. 1: peso molecular (los números la izquierda corresponden a kDa). 2: Control, células infectadas con AcMNPV (virus salvaje). 3. Células infectadas con AchiAEpapGV. B. Western Blot. 1. Células infectadas con AcMNPV (virus salvaje). 2. Células infectadas con AchiAEpapGV. 3. Sobrenadante de células infectadas con AchiAEpapGV. 4. Sobrenadante de células infectadas con AcMNPV.

En los antecedentes mencionados previamente, se describió la presencia de CHIA en cuerpos de oclusión procedentes de cultivos infectados con baculovirus (Hawtin et al., 1995). Mediante Western Blot se pudo verificar la presencia de CHIA en los OBs procedentes de céluas infectadas con AchiAEpapGV, posiblemente como contaminante o formando parte de los OBs (Fig. 4. 7). 


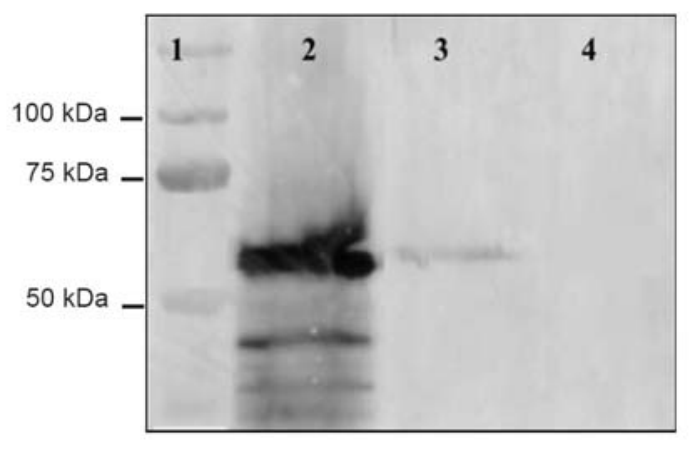

Fig. 4.7. Detección de CHIA en preparaciones de OBs extraídos de células infectadas con AchiAEpapGV. Calle 1: marcador de peso molecular. 2: Control positivo (extracto de células infectadas con AchiAEpapGV). Calle 3: OBs de AchiAEpapgV. Calle 4: OBs de wtAcMNPV (virus salvaje)

La ausencia de CHIA en OBs de wtAcMNPV observada en este trabajo posiblemente se deba a la baja concentración de cuerpos de oclusión utilizada $\left(10^{5}\right.$ $\mathrm{OB} / \mathrm{ml}$ ) ya que en estudios realizados por otros autores, en los cuales se utilizaron concentraciones mayores $\left(10^{8} \mathrm{OBs} / \mathrm{ml}\right)$, CHIA pudo ser detectada en cuerpos de oclusión de este virus (Hawtin et al., 1997). En relación a esto los mismos sostienen que es posible que CHIA no participe en las etapas iniciales de la infección cuando es administrado per os en larvas de insectos y que la falta de actividad de CHIA detectada en los poliedros, por ejemplo contra la membrana peritrófica, podría ser resultado de la baja concentración de la proteína en el OB (Hawtin et al., 1997)

Hasta el momento solo existen estudios in vitro que demuestran que la MP es dañada cuando es expuesta a dosis iguales o superiores de $7 \mu \mathrm{g} / \mathrm{ml}$ de CHIA (Rao et al., 2004), pero no existen estudios in vivo. En el próximo capítulo se describirá el efecto de OBs de AchiAEpapGV sobre la MP de A. gemmatalis.

\section{Evaluación de la actividad de CHIA}

Se realizaron estudios complementarios con el fin de caracterizar la actividad de CHIA de EpapGV bajo diferentes condiciones. En primera instancia se evaluó el sistema a utilizar, mediante el uso de una quitinasa obtenida de la bacteria Streptomyces griseus (Sigma) y quitina marcada (Chitin Azure, SIGMA), ambas disueltas en medio TC100 completo. El resultado obtenido mostró que el medio en el cual sería disuelta la quitina marcada, era adecuado para evaluar la actividad catalítica de la quitinasa (Fig. 4.8). 


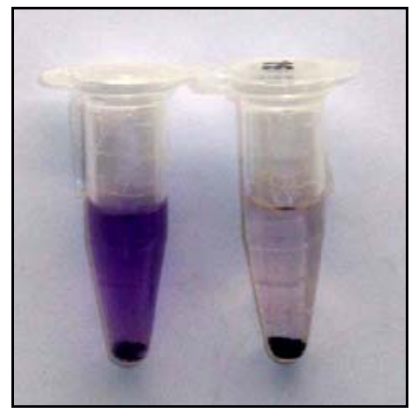

Fig. 4. 8. Izquierda: quitina marcada incubada con quitinasa de Streptomyces aureus en medio TC100 completo. Derecha: quitina marcada y TC100 completo.

Posteriormente, se utilizaron sobrenadantes de cultivos celulares infectadas con AchiAEpapGV para evaluar la actividad de la quitinasa a diferentes temperaturas y valores $\mathrm{pH}$. Según los resultados obtenidos, existe una mayor actividad enzimática a temperaturas comprendidas entre los $27^{\circ} \mathrm{C}$ y $37^{\circ} \mathrm{C}$ (Fig. 4. 9). Los sobrenadantes de las células infectadas con el virus salvaje de AcMNPV muestran actividad quitinolítica debido posiblemente a la propia quitinasa del virus.

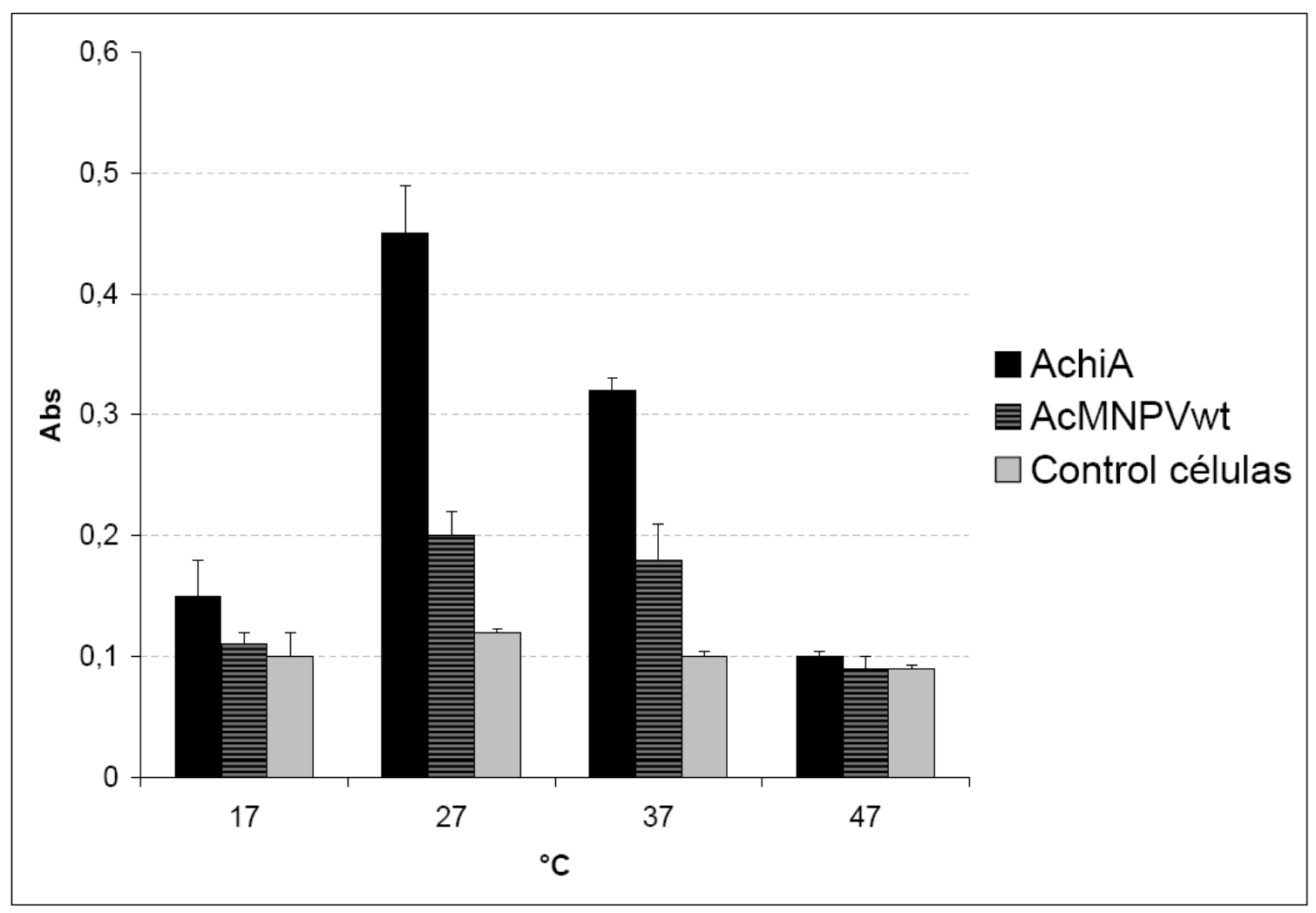

Fig. 4.9. Medición de la actividad quitinolítica de sobrenadantes procedentes de células infectadas con virus salvaje de AcMNPV, con virus AchiAEpapGV y medio TC100 tomado de células sin infectar. 
Los datos obtenidos muestran que la enzima es capaz de mantener su actividad quitinolítica a un amplio rango de $\mathrm{pH}$, siendo máxima entre 6 y 7 (Fig. 4.10). Sobrenadantes procedentes de células infectadas con el virus AcMNPV salvaje demostraron tener una actividad enzimática menor a la detectada en SN de células infectadas con el virus recombinante.

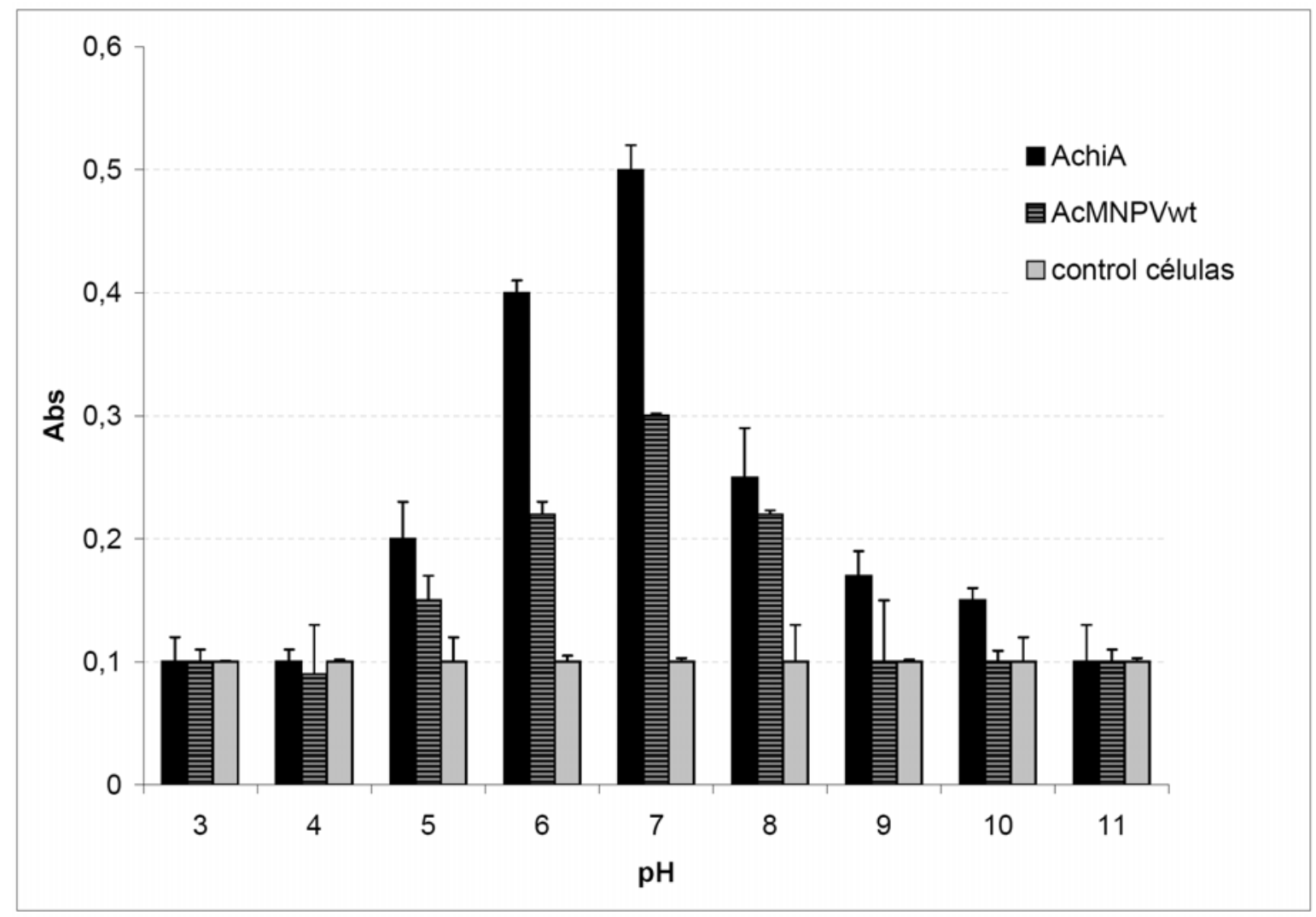

Fig. 4.10. Medición de la actividad quitinolítica de sobrenadantes de células infectadas con virus salvaje de AcMNPV, con virus AcchiAEpapGV y medio TC100 tomado de células sin infectar.

La presencia de quitinasas en una amplia diversidad de organismos hace que este tipo de enzimas posean actividad catalítica en condiciones muy diversas (Sahai, 1993). Por este motivo, se realizaron experimentos con el objetivo de determinar las condiciones óptimas de acción de la CHIA de EpapGV. Los resultados indican que la actividad se mantiene entre los $20^{\circ} \mathrm{C}$ y los $37^{\circ} \mathrm{C}$ aproximadamente. En este aspecto, en baculovirus no existen análisis de la actividad de esta enzima a diferentes temperaturas. Mientras tanto la actividad enzimática de $\mathrm{CHIA}$ a diferentes pHs está bien estudiada. En general, esta enzima puede hidrolizar la quitina en un rango de pH comprendido entre 4 y 11 (Daimon et al., 2007; Hawtin et al., 1997; 
Young et al., 2005); y los datos obtenidos en este estudio se ubican dentro de esos valores.

La detección de CHIA asociada al OB mostrada previamente, sumado a la actividad que posee la enzima a $\mathrm{pH}$ alcalino nos permite suponer la existencia de de que CHIA ataque la matriz quitinosa de la MP durante las primeras etapas de la infección per os. En base a este supuesto se realizaran ensayos que nos permitan determinar si existe un efecto de CHIA sobre la MP del hospedador.

\section{Organización genómica de las regiones flanqueantes de chiA de EpapGV y análisis filogenético}

El orden de los genes en baculovirus ha sido utilizado para hacer inferencias de sus relaciones filogenéticas (Herniou et al., 2001; Rashidan et al., 2004a; b). En este estudio se comparó la presencia y posición relativa de los genes gp37, cath y chiA en distintos genomas de baculovirus. Tanto como cath y chiA están relacionados funcionalmente en baculovirus (Daimon et al., 2007), mientras que homólogos bacterianos a gp37 y chiA están asociados en bacterias en la degradación de la quitina (Tsujibo et al., 2002). De los tres genes analizados es más constante la presencia de chiA y cath (Tabla 4.1) debido quizás, a que están asociadas funcionalmente como se explicó brevemente en la introducción de este capítulo.

En el caso de gp37, clasificado como un gen auxiliar, hay diferencias en relación a su presencia dentro de los baculovirus. Se lo encuentra presente en la mayoría de los Nucleopolyhedrovirus, está ausente en la mayoría de los Granulovirus (sólo 6 de los 13 analizados lo poseen) y ausente en todos los Nucleoplyhedrovirus aislados de himenópteros y dípteros. No se encontró ningún baculovirus con la presencia de gp37 y ausencia de chiA y cath en el mismo genoma. También, hay que destacar la ausencia de los gp37, cath y chiA en el genoma del virus de AgMNPV (Oliveira et al., 2006) utilizado en los ensayos de interacción descriptos en el capitulo II de esta tesis (Tabla 4.1) 
Tabla 4.1. Presencia (+) o ausencia (-) de los genes gp37, cath y chiA en los genomas de baculovirus

\begin{tabular}{|c|c|c|c|}
\hline Virus/ Genes & $g p 37$ & chiA & $v$-cath \\
\hline \multicolumn{4}{|l|}{ GVs } \\
\hline EpapGV, CpGV, XcGV, PieraGV, PsunGV & + & + & + \\
\hline HearGV & + & + & - \\
\hline AgSeGV & - & + & + \\
\hline CreleGV & - & + & + \\
\hline SpliGV, PxGV, AdorGV, PhopGV, ChoccGV & - & - & - \\
\hline \multicolumn{4}{|l|}{ NPVs } \\
\hline $\begin{array}{l}\text { EcobNPV, ChchNPV, TniSNPV, CIBINPV, CbNPV, } \\
\text { SFMNPV, AgseNPV, LdNPV , SpexNPV, MacoNPV- } \\
96 \mathrm{~B}, \text { MacoNPV-90/2, HzSNPV, HearNPV, SpINPV, } \\
\text { LeseNPV, MaruMNPV, BmNPV, EppoNPV, OpMNPV, } \\
\text { HyCuNPV, AnpeNPV, PxMNPV, RanuMNPV, } \\
\text { CfDEFMNPV, AcMNPV }\end{array}$ & + & + & + \\
\hline AgMNPV & - & - & - \\
\hline AdhoNPV & - & - & + \\
\hline
\end{tabular}

Si bien la secuencia aminoacídica codificada por estos tres genes es relativamente conservada en todos los baculovirus, el agrupamineto de los mismos en los genomas resulta ser variable. Genomas como AcMNPV y OpMNPV ó EpapGV, CpGV y el recientemente secuenciado Pieris rapae Granulovirus presentan un orden similar en la organización de gp37, cath y chiA. En el caso de CrleGV los genes cath y chiA presentan el mismo agrupamiento que el encontrado en EpapGV y CpGV, sólo con la diferencia que gp37 está ausente (Fig.4.11)

Un análisis completo del grupo de genes gp37, cath y chiA reveló que la presencia de estos genes resultó ser más variable en los Betabaculovirus donde aproximadamente solo el $30 \%$ de los secuenciados hasta el momento poseen los 3 ORFs, que en los Alphabaculovirus en los cuales casi un $80 \%$ los poseen. El ORF correspondiente a gp37, según este análisis, nunca aparece solo en los genomas baculovirales, su presencia siempre está acompañada de chiA y cath, a excepción de HearGV cuyo genoma posee gp37 y chiA pero cath está ausente. 


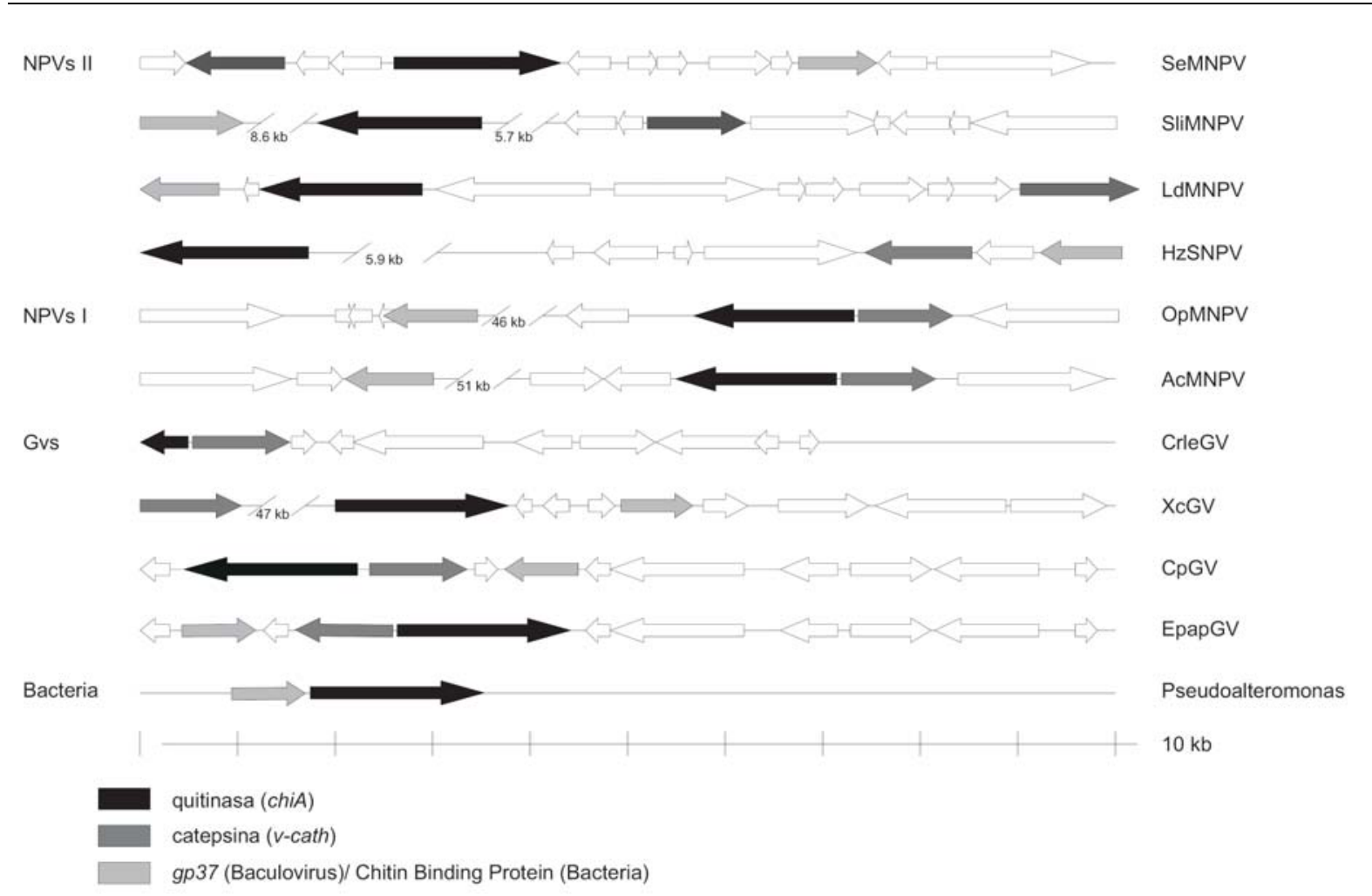

Fig. 4.11. Posición relativa de los genes gp37 ( $c b p$ en bacterias), cath y chiA en diferentes genomas de baculovirus y comparación con la hallada también en algunas bacterias. Entre barras aparece el número de nucleótidos (expresados en $\mathrm{kpb}$ ) encontrado en algunos genomas entre los genes estudiados.

La filogenia del ORF de la quitinasa baculoviral fue analizada en repetidas ocasiones (Daimon et al., 2003; Kang et al., 1998; Wang et al., 2004). El último trabajo -publicado en el 2004-, se realizó incluyendo un número mayor de secuencias que en los anteriores y sostiene la relación monofilética entre las quitinasas de los baculovirus y bacterias del grupo de las gammaprotebacterias como Serratia marcescens y Burkholdera cepacia, entre otras. Está bien documentado que la filogenia del gen de la quitinasa solo concuerda parcialmente con la filogenia de genes del ARNr 16S, la cual es la base de la actual filogenia bacteriana. Se supone que eventos de transferencia horizontal del gen de quitinasas entre bacterias es la razón de esta desviación (Cottrell et al., 2000). A pesar de la misma, los autores sostienen que no se ve afectada la conclusión de que la mayoría de las quitinasas de los baculovirus derivarían de proteobacterias (Wang et al., 2004). 
A diferencia del planteo anterior realizado con 9 secuencias baculovirales (7 NPVs y $2 \mathrm{GVs}$ ), en nuestro análisis se incluyó un total de 26 secuencias virales. De esta forma los Granulovirus aparecen como grupo hermano de las bacterias, separándose de los Nucleopolyhedrovirus (Fig.4.11).

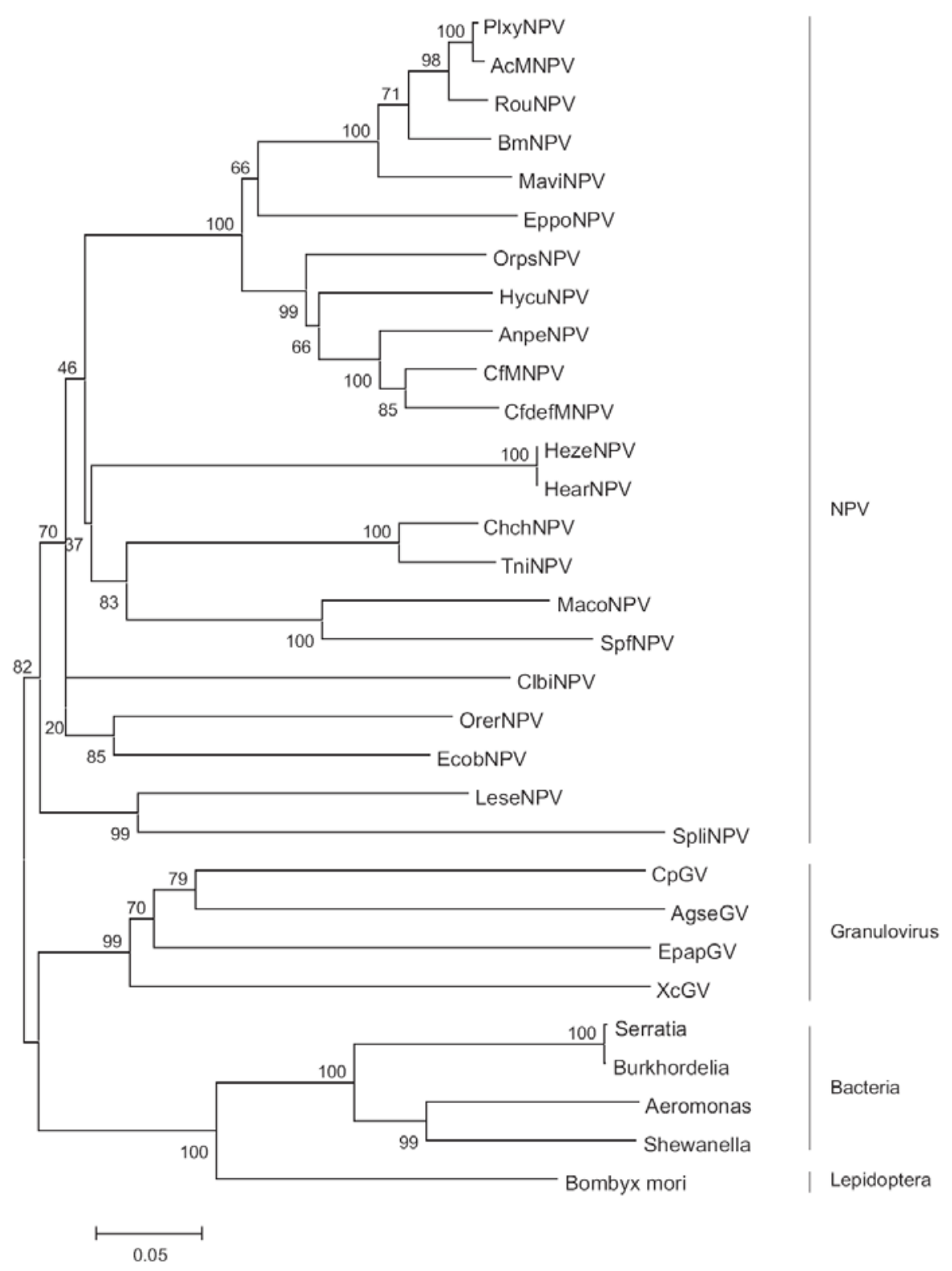

Fig. 4.11. Árbol filogenético de CHIA de EpapGV y quitinasas de diferentes grupos taxonómicos

Esta relación difiere de los agrupamientos observados en estudios filogenéticos anteriores en los cuales GVs y NPV estaban incluidos dentro del mismo (Hawtin et al., 1995; Wang et al., 2004). Para esclarecer estas diferencias será necesario un 
mayor número de secuencias de Granulovirus disponibles que permitan corroborar las relaciones observadas en este estudio.

También se incluyó en este trabajo la chiA presente en el genoma del lepidóptero Bombyx mori. El elevado valor de boopstrap en el agrupamiento que vincula esta secuencia a las bacterianas, indican el estrecho vínculo existente entre ambas y es coincidente al obtenido en análisis previos (Daimon et al., 2003).

En el Capitulo 3 de esta tesis, el análisis filogenético de GP37, reveló su vínculo con las chitin binding proteins (CBPs) bacterianas. El estudio de genes bacterianos implicados en la degradación de la quitina, demuestra la existencia de un bloque que incluye a una quitinasa (chiA), homóloga a la encontrada en los baculovirus y una chitin binding protein (cbp), relacionada entre otros con gp37 de los baculovirus (Watanabe et al., 1997; Techkarnjanaruk \& Goodman, 1999; Tsujibo et al., 2002). Según lo descrito, las CPPS actúan optimizando la acción catalítica de la quitinasa sobre la quitina. La unión de la CBP a la quitina, generaría cambios estructurales en la misma que facilitarían el acceso de la quitinasa e incrementaría su acción (Howard et al., 2003; Tsujibo et al., 2002). Teniendo en cuenta que la disposición de estos genes (chiA-cbps) en algunas bacterias (Tsujibo et al., 2002), es muy similar a la que se encuentra en los Baculovirus (Fig. 4.11), se podría postular no solo el origen bacteriano de las gp37 virales sino también que la transferencia ocurrida entre bacterias y virus incluyó conjuntamente tanto a chiA como a gp37. Esta suposición queda fundamentada por la similitud en la topología de los árboles filogenéticos realizados tanto para quitinasa como para gp37.

La asociación funcional que existe entre chiA y cbps en bacterias no está demostrada hasta el momento con sus homólogos en los baculovirus. 


\section{Referencias}

Cohen-Kupiec, R. \& Chet, I. (1998). The molecular biology of chitin digestion. Curr Opin Biotechnol 9, 270-277.

Cottrell, M. T., Wood, D. N., Yu, L. \& Kirchman, D. L. (2000). Selected chitinase genes in cultured and uncultured marine bacteria in the alpha- and gamma-subclasses of the proteobacteria. Appl Environ Microbiol 66, 1195-1201.

Daimon, T., Hamada, K., Mita, K., Okano, K., Suzuki, M. G., Kobayashi, M. \& Shimada, T. (2003). A Bombyx mori gene, BmChi-h, encodes a protein homologous to bacterial and baculovirus chitinases. Insect Biochem Mol Biol 33, 749-759.

Daimon, T., Katsuma, S., Iwanaga, M., Kang, W. \& Shimada, T. (2005). The BmChi-h gene, a bacterial-type chitinase gene of Bombyx mori, encodes a functional exochitinase that plays a role in the chitin degradation during the molting process. Insect Biochem Mol Biol 35, 1112-1123.

Daimon, T., Katsuma, S., Kang, W. K. \& Shimada, T. (2007). Functional characterization of chitinase from Cydia pomonella granulovirus. Arch Virol 152, 1655-1664.

Davies, G. \& Henrissat, B. (1995). Structures and mechanisms of glycosyl hydrolases. Structure 3, 853-859.

Fukamizo, T. (2000). Chitinolytic enzymes: catalysis, substrate binding, and their application. Curr Protein Pept Sci 1, 105-124.

Harman, G. E., Hayes, C. K., Lorito, M., Broadway, R. M., Pietro, A. D., and Tronsmo, A. (1993). Chitinolytic enzymes of Trichoderma harzianum purification of chitobiosidase and endochitinase. Phytopathology 83:313-318

Hawtin, R. E., Arnold, K., Ayres, M. D., Zanotto, P. M., Howard, S. C., Gooday, G. W., Chappell, L. H., Kitts, P. A., King, L. A. \& Possee, R. D. (1995). Identification and preliminary characterization of a chitinase gene in the Autographa californica nuclear polyhedrosis virus genome. Virology 212, 673-685. 
Hawtin, R. E., Zarkowska, T., Arnold, K., Thomas, C. J., Gooday, G. W., King, L. A., Kuzio, J. A. \& Possee, R. D. (1997). Liquefaction of Autographa californica nucleopolyhedrovirus-infected insects is dependent on the integrity of virus-encoded chitinase and cathepsin genes. Virology 238, 243-253.

Henrissat, B. (1991). A classification of glycosyl hydrolases based on amino acid sequence similarities. Biochem J 280 ( Pt 2), 309-316.

Henrissat, B. (1999). Classification of chitinases modules. EXS 87, 137-156.

Henrissat, B. \& Romeu, A. (1995). Families, superfamilies and subfamilies of glycosyl hydrolases. Biochem J 311 ( Pt 1), 350-351.

Herniou, E. A., Luque, T., Chen, X., Vlak, J. M., Winstanley, D., Cory, J. S. \& O'Reilly, D. R. (2001). Use of whole genome sequence data to infer baculovirus phylogeny. J Virol $75,8117-8126$.

Hom, L. G. \& Volkman, L. E. (2000). Autographa californica M nucleopolyhedrovirus chiA is required for processing of V-CATH. Virology 277, 178-183.

Howard, M. B., Ekborg, N. A., Weiner, R. M. \& Hutcheson, S. W. (2003). Detection and characterization of chitinases and other chitin-modifying enzymes. $J$ Ind Microbiol Biotechnol 30, 627-635.

Kang, W., Tristem, M., Maeda, S., Crook, N. E. \& O'Reilly, D. R. (1998). Identification and characterization of the Cydia pomonella granulovirus cathepsin and chitinase genes. J Gen Virol 79 ( Pt 9), 2283-2292.

Keyhani, N. O. \& Roseman, S. (1996). The chitin catabolic cascade in the marine bacterium Vibrio furnissii. Molecular cloning, isolation, and characterization of a periplasmic chitodextrinase. J Biol Chem 271, 33414-33424.

Laemmli, U. K. (1970). Cleavage of structural proteins during the assembly of the head of bacteriophage T4. Nature 227, 680-685.

Merzendorfer, H. \& Zimoch, L. (2003). Chitin metabolism in insects: structure, function and regulation of chitin synthases and chitinases. J Exp Biol 206, 4393-4412. 
Ohkawa, T., Majima, K. \& Maeda, S. (1994). A cysteine protease encoded by the baculovirus Bombyx mori nuclear polyhedrosis virus. J Virol 68, 6619-6625.

Oliveira, J. V., Wolff, J. L., Garcia-Maruniak, A., Ribeiro, B. M., de Castro, M. E., de Souza, M. L., Moscardi, F., Maruniak, J. E. \& Zanotto, P. M. (2006). Genome of the most widely used viral biopesticide: Anticarsia gemmatalis multiple nucleopolyhedrovirus. J Gen Virol 87, 3233-3250.

Parola, A. D., Manzan, M. A., Lozano, M. E., Ghiringhelli, P. D., Sciocco-Cap, A. \& Romanowski, V. (2002). Physical and genetic map of Epinotia aporema granulovirus genome. Virus Genes 25, 329-341.

Perrakis, A., Tews, I., Dauter, Z., Oppenheim, A. B., Chet, I., Wilson, K. S. \& Vorgias, C. E. (1994). Crystal structure of a bacterial chitinase at 2.3 A resolution. Structure 2, 1169-1180.

Rao, R., Fiandra, L., Giordana, B., de Eguileor, M., Congiu, T., Burlini, N., Arciello, S., Corrado, G. \& Pennacchio, F. (2004). AcMNPV ChiA protein disrupts the peritrophic membrane and alters midgut physiology of Bombyx mori larvae. Insect Biochem $\mathrm{Mol}$ Biol 34, 1205-1213.

Rashidan, K. K., Nassoury, N., Giannopoulos, P. N., Mauffette, Y. \& Guertin, C. (2004). Identification, characterization and phylogenic analysis of conserved genes within the odvp-6e/odv-e56 gene region of Choristoneura fumiferana granulovirus. J Biochem Mol Biol 37, 206-212.

Rawlings, N. D., Pearl, L. H. \& Buttle, D. J. (1992). The baculovirus Autographa californica nuclear polyhedrosis virus genome includes a papain-like sequence. Biol Chem Hoppe Seyler 373, 1211-1215.

Reynolds, S. E. (1996). Physiology and biochemistry of insect moulting fluid. Adv Insect Physiol 26, 157-232.

Sahai, A. S., and Manocha, M. S. (1993). Chitinases of fungi and plants: Their involvement in morphogenesis and host parasite interaction. FEMS Microbiol Rev 11:317-338. 
Shinshi, H., Neuhas, J. M., Ryals, J. \& Meins, F., Jr. (1990). Structure of a tobacco endochitinase gene: evidence that different chitinase genes can arise by transposition of sequences encoding a cysteine-rich domain. Plant Mol Biol 14, 357368.

Slack, J. M., Kuzio, J. \& Faulkner, P. (1995). Characterization of v-cath, a cathepsin L-like proteinase expressed by the baculovirus Autographa californica multiple nuclear polyhedrosis virus. J Gen Virol 76 ( Pt 5), 1091-1098.

Techkarnjanaruk, S. \& Goodman, A. E. (1999). Multiple genes involved in chitin degradation from the marine bacterium Pseudoalteromonas sp. strain S91. Microbiology 145 ( Pt 4), 925-934.

Thompson, J. D., Gibson, T. J., Plewniak, F., Jeanmougin, F. \& Higgins, D. G. (1997). The CLUSTAL_X windows interface: flexible strategies for multiple sequence alignment aided by quality analysis tools. Nucleic Acids Res $25,4876-4882$.

Tsujibo, H., Orikoshi, H., Baba, N., Miyahara, M., Miyamoto, K., Yasuda, M. \& Inamori, Y. (2002). Identification and characterization of the gene cluster involved in chitin degradation in a marine bacterium, Alteromonas sp. strain 0-7. Appl Environ Microbiol 68, 263-270.

Vaughn, J. L., Goodwin, R. H., Tompkins, G. J. \& McCawley, P. (1977). The establishment of two cell lines from the insect Spodoptera frugiperda (Lepidoptera; Noctuidae). In Vitro 13, 213-217.

Wang, H., Wu, D., Deng, F., Peng, H., Chen, X., Lauzon, H., Arif, B. M., Jehle, J. A. \& Hu, Z. (2004). Characterization and phylogenetic analysis of the chitinase gene from the Helicoverpa armigera single nucleocapsid nucleopolyhedrovirus. Virus Res 100, 179189

Watanabe, T., Kimura, K., Sumiya, T., Nikaidou, N., Suzuki, K., Suzuki, M., Taiyoji, M., Ferrer, S. \& Regue, M. (1997). Genetic analysis of the chitinase system of Serratia marcescens 2170. J Bacteriol 179, 7111-7117. 
Wickham, T. J., Davis, T., Granados, R. R., Shuler, M. L. \& Wood, H. A. (1992). Screening of insect cell lines for the production of recombinant proteins and infectious virus in the baculovirus expression system. Biotechnol Prog 8, 391-396.

Young, V. L., Simpson, R. M. \& Ward, V. K. (2005). Characterization of an exochitinase from Epiphyas postvittana nucleopolyhedrovirus (family Baculoviridae). J Gen Virol 86, 3253-3261. 


\section{Capítulo 5}

Evaluación de genes de EpapGV en baculovirus recombinantes 


\section{Indice temático}

$\begin{array}{ll}\text { Introducción } & 116\end{array}$

$\begin{array}{ll}\text { Materiales y métodos } & 122\end{array}$

$\begin{array}{ll}\text { Resultados } & 129\end{array}$

Generación de recombinantes de AgMNPV. 130

Evaluación de la expresión de genes de interés mediante Western Blot

Evaluación de virus recombinantes de AcMNPV 


\section{Introducción}

Dentro de los patógenos utilizados para controlar plagas en los cultivos, los baculovirus han sido usados ampliamente porque tienen la capacidad de controlar la especie plaga sin generar patogenicidad cruzada a otras especies no blanco, las cuales pueden actuar como enemigos naturales de las mismas plagas. El nucleopoliedrovirus de Autographa californica (Lepidoptera: Noctuidae) denominado AcMNPV fue uno de los primeros descriptos y el interés en su estudio empezó cuando se observó que controlaba poblaciones de $A$. californica, las cuales destruían masivamente cultivos de alfalfa (Cory \& Bishop, 1995).En 1970, se aplicó extensivamente en campos del suroeste de Ontario con el fin de estudiar la efectividad contra el gusano de la col, Trichoplusia ni. (Hubner) (Lepidoptera: Noctuidae) (Richards et al., 1998).

Desde 1970, con el desarrollo de la biología molecular, la investigación de los virus de insectos, especialmente baculovirus, se fue incrementado y las nuevas técnicas de ingeniería genética hicieron posible el inicio de la modificación de su genoma. A fines de los 80, se realizaron en Inglaterra los primeros ensayos en campo con baculovirus genéticamente modificados (AcMNPVpol-lacZ) (Black, 1997; Levidow, 1995) y en el año 1989, en Estados Unidos (Wood, 1994). Estos ensayos realizados con virus polh-, tenían como objetivo evaluar la persistencia de los mismos en elambiente. En el año 1993, se evaluó el primer AcMNPV recombinante polh+que expresaba una neurotoxina específica de insectos (AalT) causando un efecto paralizante en las larvas infectadas y resultando en una disminución del daño en los cultivos de más del $50 \%$ (Cory et al., 1994).

Si bien numerosos estudios han concluido que las toxinas selectivas expresadas en los baculovirus recombinantes no son dañinas para organismos no blanco, el uso de otros tipos de genes (tales como hormonas juveniles, proteasas, quitinasas $u$ otras enzimas) es visto como una alternativa más segura (Bora Inceouglu et al., 2008). 
Actualmente las investigaciones se dirigen especialmente hacia la obtención de baculovirus recombinantes, modificados para aumentar el rango de huéspedes o disminuir el tiempo letal (Inceoglu et al., 2006; Cory \& Bishop, 1995; Richards et al., 1998). Si bien se han realizado varios estudios con el fin de definir cuáles son los determinantes genéticos que permiten ampliar el rango de hospedantes (Birnbaum et al., 1994; Katou et al., 2006; McCarthy \& Theilmann, 2008), no se ha podido establecer un esquema válido para todas las especies.

En teoría, cualquier gen que codifique una proteína capaz de interrumpir el desarrollo normal, de modificar el comportamiento de una larva o reducir el daño causado por la alimentación de los insectos sobre el cultivo se convierte en candidato para su inclusión en un virus recombinante con probabilidades de ser un agente de control biológico mejorado.

Desde el punto de vista teórico, se pueden considerar dos tipos de modificaciones: por un lado, disminuir su especificidad, ampliando de esta forma el rango de hospedadores y, por el otro, modificar los factores de eficacia insecticida del virus (Lopez-Ferber et al., 2001) Este último tipo de modificaciones tiene como objetivo mejorar la actividad del virus en su propio hospedador. Esta mejora puede ser de dos tipos: 1) disminución en la cantidad de cuerpos de oclusión necesarios para matar al insecto, el cual generalmente se expresa en Dosis Letal Media (DL50); 2) disminución del tiempo necesario para matar las larvas que se expresa en Tiempo Letal Medio (TL50) (Lopez-Ferber et al, 2001). Con tales objetivos se desarrollaron numerosos baculovirus algunos de los cuales fueron capaces de mejorar la acción insecticida de los mismos. El descubrimiento de los vef (descritos en el Capítulo 1) en Trichoplusia ni granulovirus (TnGV) (Tanada et al., 1973) y el posterior conocimiento del modo de acción sobre la membrana peritrófica (MP) del hospedador (Bischoff \& Slavicek, 1997; Derksen \& Granados, 1988a; Lepore et al., 1996; Peng et al., 1999; Wang \& Granados, 1997), llevaron a la construcción de baculovirus recombinantes con este gen. Los resultados demostraron que la incorporación del vef de TnGV en el genoma de AcMNPV produjo una disminución de 2,1 veces la DL50 y 1,3 veces el TL50 en comparación con el virus de AcMNPV salvaje (Rincón-Castro, 1997). 
Finalmente, otra alternativa ensayada con éxito ha consistido en generar modificaciones que alteren la fisiologia de hospedador, así el producto del gen viral egt (ecdysteroid UDP-glycosyltransferase) extiende el estado larval al inactivar los ecdisteroides que actúan como hormonas que regulan la muda del insecto ( $O$ 'Reilly \& Miller, 1991). La comparación entre larvas infectadas con aislamientos silvestres de AcMNPV y con AcMNPV $\triangle$ egt (en el que se ha eliminado el gen egt), mostraron que las larvas infectadas con este último presentaban una reducción significativa del peso, reducción del $40 \%$ en la cantidad de alimento consumido y del $20 \%$ en el tiempo letal medio del virus (Cross et al., 1991). Experiencias similares fueron conducidas con otros baculovirus, tales como HearNPV y AgMNPV (Sun et al., 2002; Ribeiro \& Pinedo, 2001).

Los resultados expuestos en el capítulo 2 de esta tesis, mostraron la existencia de factores codificados en el genoma de EpapGV capaces de aumentar la virulencia en mezclas virales administradas sobre larvas de Anticarsia gemmatalis. En base a los datos disponibles hasta el momento, se seleccionaron y estudiaron genes que podrían estar involucrados en los efectos observados in vivo en las mezclas virales ensayadas. Los genes gp37 y chiA, están ausentes en el genoma de AgMNPV (Oliveira et al., 2006) y por lo tanto se consideraron como buenos candidatos para ser empleados en la modificación genética de este virus con el fin de incrementar su actividad insecticida y potenciar su uso como agente de biocontrol.

En algunos baculovirus, tanto GP37 como CHIA parecen encontrarse asociados al cuerpo de oclusión (Gross et al., 1993; Hawtin et al., 1997; Li et al., 2003; Vialard et al., 1990). Estudios previos muestran que factores presentes en los OBs son capaces de alterar la estructura de la MP (Derksen \& Granados, 1988b). Si bien se demostró que los OBs poseen CHIA con actividad quitinolítica (Hawtin et al., 1997), los efectos de esta enzima sobre la MP solo fueron demostrados in vitro (Rao et al., 2004). Para el caso de GP37, en algunos NPVs es detectada en los OBs, pero el bajo nivel de expresión observado durante la infección sea quizás el motivo por el cual no puede evidenciarse su actividad sobre la MP del hospedador con baculovirus que contienen ese gen funcional (Li et al., 2003).

Sobre la base de estos antecedentes, se encaró la generación de baculovirus capaces de sobreexpresar GP37, CATH y CHIA, como herramientas que aporten 
datos sobre el papel de estas proteínas en las etapas iniciales del ciclo infectivo de los baculovirus y puedan ser utilizables en el mejoramiento de su eficiencia como bioinsecticidas. Además, cabe considerar que la ausencia de los genes que codifican para estas proteínas en AgMNPV (Oliveira et al. 2006), convierten a este virus en un modelo óptimo para la realización de estudios de caracterización funcional. 


\section{Materiales y métodos}

Células y virus. Para la obtención de virus AgMNPV recombinantes se utilizaron células derivadas de Anticarsia gemmatalis (UFLAG-286) (Sieburth et al., 1988) que fueron mantenidas a $27^{\circ} \mathrm{C}$ en medio TC-100 (JRH Bioscience) suplementado con $10 \%$ de suero fetal bovino (Bioser) y $50 \mu \mathrm{g} / \mathrm{ml}$ de gentamicina (Parafarm). El virus AgMNPV-IPpol (McCarthy, 2005) fue propagado en monocapa de células UFLAg286 y cuantificado mediante ensayo de placas siguiendo el protocolo de O'Reilly (1992). La obtención de los virus recombinantes AchiAEpapGV, Acgp37EpapGV fue descrita anteriormente.

Clonado de genes de EpapGV. Utilizando el vector de transferencia pl2 (Biedma, 2009) se construyeron plásmidos recombinantes del tipo pl2-X conteniendo distintos ORFs X de EpapGV. Los ORFs de EpapGV seleccionados fueron amplificados mediante PCR utilizando como molde DNA viral de EpapGV y primers específicos. Para la amplificación del fragmento genómico que contiene el bloque de los ORFs gp37-cath-chiA se utlizaron los primers gp37Ep-Up-EcoRI y chiA-Down-Xhol. Los productos de PCR fueron separados por electroforesis en geles de agarosa, aislados y digeridos con enzimas de restricción para su clonado en el vector pl2, previamente digerido con las mismas enzimas. Los plásmidos obtenidos se denominaron pl2-gp37, pl2-chiA, y pl2-4kb (bloque gp37-cath-chiA). Los mismos se analizaron mediante PCR, perfiles de restricción y secuenciación. Los primers utilizados para amplificar los respectivos ORF se detallan a continuación, indicando el nombre, secuencia, Tm, \%CG y longitud del amplicón, respectivamente:

\begin{tabular}{|c|c|c|c|c|}
\hline gp37Ep-Up-EcoRI & 5' GGAATTCCAGATATGATAGTACTGATAATATTG 3' & 55.4 & 30.3 & \multirow{2}{*}{$689 \mathrm{pb}$} \\
\hline gp37Ep-Down-Pstl & 5' AACTGCAGTTAAAACTCGTCATTTTGT 3' & 56 & 33.3 & \\
\hline chiA-Up-Kpnl & 5' TGGTACCGTATGAAACTAGCAATTGTGTC 3' & 59.6 & 41.4 & \multirow{2}{*}{$1731 \mathrm{pb}$} \\
\hline chiA-Down-Xhol & 5' GGCTCGAGGCTATCCTTTACAGAACGCGTCAAGTCC 3' & 63.9 & 55.6 & \\
\hline
\end{tabular}

Linealización del DNA viral de AgMNPV-IPpol. Para la reacción de digestión del ADN viral AgMNPV-IPpol con la enzima de restricción IPpol, se siguió el protocolo propuesto por McCarthy (2005) en el cual se utiliza buffer E (Promega) en lugar del 
buffer recomendado por el fabricante de la enzima. Las condiciones de incubación y cantidad de enzima que se usaron fueron las recomendadas por el proveedor.

Obtención de recombinantes de AgMNPV. Se sembraron $1 \times 10^{6}$ células UFLAg286 sobre placas de $35 \mathrm{~mm}$ y se incubaron $\mathrm{ON}$ a $27^{\circ} \mathrm{C}$ para favorecer su adhesión a la superficie. Las células fueron cotransfectadas con una mezcla de $500 \mathrm{ng}$ de ADN genómico de AgMNPV-IPpol linealizado y $1 \mu \mathrm{g}$ del plásmido de transferencia correspondiente (pl2-x) (Biedma, 2009). Se utilizaron los lípidos Insect-GeneJuice (Novagen) siguiendo el protocolo del fabricante. Brevemente, los DNA viral y plasmídico fueron diluidos en $100 \mu \mathrm{l}$ de TC-100 libre de suero (solución A), $2 \mu \mathrm{l}$ de reactivo de transfección fue diluido en $100 \mu \mathrm{l}$ de TC-100 libre de suero (solución B), la solución B fue agregada gota a gota a la solución A y esta mezcla incubada a temperatura ambiente por $45 \mathrm{~min}$. Pasado este lapso se agregaron $800 \mu \mathrm{l}$ de medio TC-100 libre de suero. La mezcla final fue agregada a la monocapa celular, previamente lavada dos veces con PBS $1 \mathrm{X}$, e incubada por $4 \mathrm{~h}$ a $27^{\circ} \mathrm{C}$. Luego, se agregaron $2 \mathrm{ml}$ de TC-100 suplementado con $10 \%$ de suero. Al cabo de seis días, se recolectó el medio sobrenadante, conteniendo la progenie viral. Los virus recombinantes fueron purificados mediante ensayos de placa sucesivos (O'Reilly, 1992). La detección de los virus recombinantes fue monitoreada por la aparición de poliedros y mediante PCR (McCarthy, 2005).

\section{Generación de un recombinante AcMNPV-eGFP. El ORF completo} correspondiente a la proteína fluorescente (green fluorescent protein, eGFP) fue obtenido a partir del plásmido pGemT-eGFP (Ure, 2009) mediante digestión con la enzima EcoRI y clonado posteriormente en el vector pBacPack 9 (Invitrogen) digerido con la misma enzima. Una vez ligados inserto y vector, se transformaron células $\mathrm{DH} 5 \mathrm{a}$ electrocompetentes. Las colonias seleccionadas mediante la utilización de ampicilina fueron analizadas mediante colony $P C R$ usando los primers bac 1 (5-'AACCATCTCGCAAATAAATA-3') y bac2 (5'-AAGCGCTAGATTCTGTGC GT-3') cuyos sitios de pegado corresponden a regiones externas y flanqueantes al sitio de inserción del ORF. Mediante la combinación de primers bac y eGFP se determinó la correcta orientación del inserto. El plásmido obtenido, denominado pbGFP, fue purificado y utilizado para cotransfectar junto a DNA del bácmido de 
AcGOZA (sistema descrito anteriormente) (Fig. 5.1), en células SF-9 sembradas en placas de $35 \mathrm{~mm}\left(0.5 \times 10^{6}\right.$ células). El reactivo de transfección Insect-GeneJuice (Novagen) fue utilizado siguiendo las especificaciones y recomendaciones del fabricante. Las células fueron mantenidas a $27^{\circ} \mathrm{C}$ por $4 \mathrm{~h}$ con la mezcla lípidos-DNA y luego la misma fue reemplazada por medio TC-100 suplementado con $10 \%$ de suero fetal bovino. La incubación a $27^{\circ} \mathrm{C}$ se extendió hasta el momento de observar la presencia de células con poliedros. El sobrenadante de la transfección conteniendo el recombinante AcGFP fue utilizado para reinfectar células Sf9 y el segundo pasaje se realizó sobre células de Trichoplusia ni (HighFive). La presencia del virus recombinante se confirmó mediante la presencia de poliedros y fluorescencia de las monocapas infectadas sometidas a luz UV.

Purificación de DNA viral a pequeña escala. Los BV se aislaron a partir del sobrenadante del cultivo de células infectadas. El sobrenadante se clarificó por centrifugación a $1000 \times \mathrm{g}$ a $4{ }^{\circ} \mathrm{C}$ durante $5 \mathrm{~min}$. La precipitación de los viriones se realizó centrifugando $1,5 \mathrm{ml}$ de este sobrenadante a $14-18.000 \mathrm{rpm}$ y $4{ }^{\circ} \mathrm{C}$ durante $30 \mathrm{~min}$ en un tubo eppendorf. Luego se descartó el sobrenadante. Este procedimiento se repitió tres veces en el mismo tubo. El pellet de viriones se resuspendió delicadamente en buffer de lisis [Tris- $\mathrm{HCl}(\mathrm{pH} \mathrm{7,6)} 10$ mM; EDTA 10 $\mathrm{mM}$; SDS $0,25 \%$ ], se agregó proteinasa $\mathrm{K}(500 \mu \mathrm{g} / \mathrm{ml})$ y se incubó a $60{ }^{\circ} \mathrm{C}$ durante un mínimo de $2 \mathrm{~h}$. Se realizaron tres extracciones sucesivas (fenol/ fenolcloroformo-isoamílico/ cloroformo-isoamílico), agregando $500 \mu \mathrm{l}$ de solvente orgánico en cada caso. Se llevó la fase acuosa a una concentración final de 0,2 M $\mathrm{NaCl}$, se agregó $500 \mu \mathrm{l}$ de isopropanol para precipitar y posteriormente se lavó el pellet con $500 \mu \mathrm{l}$ de etanol $70 \%$, se centrifugó a $14000 \mathrm{rpm}$ a $4^{\circ} \mathrm{C}$ por $30 \mathrm{~min}$. El pellet se resuspendió en $20 \mu \mathrm{l}$ de agua bidestilada estéril y fue utilizado para detectar recombinantes mediante la técnica de PCR. 


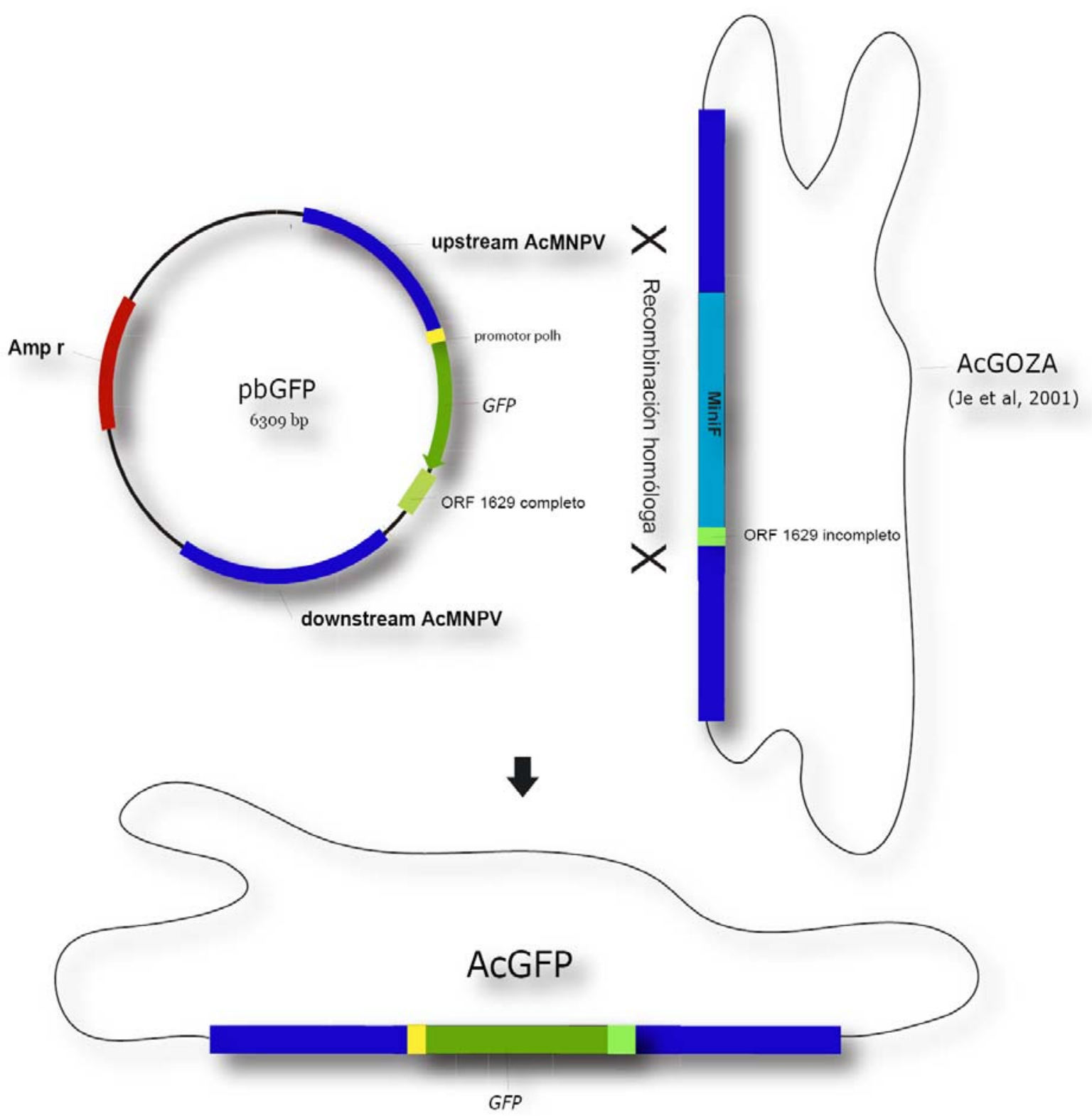

Promotor de poliedrina

ORF de interés

Mini-F

Regiones de recombinación

ORF 1629

Fig. 5.1. Generación del recombinante Ac-eGFP mediante recombinación homóloga en células de insecto entre el plásmido pbGFP y DNA del bácmido de AcMNPV Ac-GOZA. 
SDS-PAGE y Western Blot. Células UFLAG-286 infectadas con el virus rAgMNPV/gp37-polh+ obtenido fueron colectadas a las 72 hs postinfección, lavadas dos veces con buffer PBS, centrifugadas y resuspendidas en sample buffer. Como control positivo se utilizaron células infectadas con el recombinante Acgp37EpapGV tratadas de igual manera. Posteriormente, las muestras fueron separadas por electroforesis en gel de poliacrilamida al 10\% (SDS-PAGE) (Laemmli, 1970), usando el equipo Mini-protean II (Bio-Rad). Las proteínas se transfirieron a una membrana de PVDF (Immobilon-Psq; Millipore, Bedford, MA) usando una aparato Semidry Transblot (Bio-Rad). La transferencia se realizó a $15 \mathrm{~V}$ por $30 \mathrm{~min}$. Posteriormente, las membranas se incubaron en una solución de bloqueo (PBS conteniendo $5 \%$ de leche descremada) por $1 \mathrm{~h}$ a temperatura ambiente. Las membranas fueron incubadas durante 1 hora a temperatura ambiente con una dilución 1:5.000 del anticuerpo anti-fusolin AcEPV y posteriormente se lavó tres veces con PBS (0,05\% de Tween 20). A continuación, la membrana fue incubada $1 \mathrm{~h}$ con una dilución 1:5.000 de anticuerpos anti-lgG de ratón conjugados a HRP (Santa Cruz Biotechnology). Posteriormente se lavaron en PBS (0,05\% de Tween 20) y revelada con DAB (Sigma) y $\mathrm{H}_{2} \mathrm{O}_{2}$. Como controles negativos se utilizaron células UFLAg286 sin infectar, y células infectadas con el virus salvaje de AgMNPV.

Insectos. Las larvas de A. gemmatalis, Epinotia aporema y Spodoptera frugiperda empleadas para los bioensayos fueron provistas por el insectario del IMYZA-INTA, Castelar. La cría de insectos se realizó bajo condiciones controladas de temperatura $\left(26 \pm 1^{\circ} \mathrm{C}\right)$, humedad relativa $(50-70 \%)$ fotoperíodo $(14: 10 \mathrm{~L} / \mathrm{O})$ y fueron mantenidas en dieta artificial (Greene et al., 1976).

\section{Bioensayos con virus AchiAEpapgV y Acgp37EpapgV sobre larvas de} Anticarsia gemmatalis, Epinotia aporema y Spodoptera frugiperda. Los ensayos in vivo fueron realizados según la metodología descripta por Hughes y Wood (1986) descripta anteriormente (Cap. 2), en larvas de $3^{\text {er }}$ estadio de las especies mencionadas. Las dosis utilizadas se muestran en la Tabla 5.1. Se ensayaron las diferentes dosis de rAcMNPV sobre 15 individuos por grupo, los ensayos se repitieron al menos 3 veces. Como control negativo se utilizó la mezcla fagoestimulante coloreada. La mortalidad fue registrada a intervalos de $24 \mathrm{~h}$. 
Tabla 5.1. Dosis, virus y larvas utilizadas para la evaluación de los recombinantes AchiAEpapGV y Acgp37EpapGV

\begin{tabular}{|c|c|c|}
\hline Dosis (OBs/larva) & Virus & Especie \\
\hline $1500-1500$ & AcGFP-Acgp37 & A. gemmatalis \\
$1500-1500$ & AcMNPVwt-AcGFP & A. gemmatalis \\
3000 & AcGFP & A. gemmatalis \\
\hline $1500-1500$ & AcGFP-Acgp37 & S. frugiperda \\
$1500-1500$ & AcMNPVwt-AcGFP & S. frugiperda \\
3000 & AcGFP & S. frugiperda \\
\hline $1500-1500$ & AcGFP-Acgp37 & E.aporema \\
$1500-1500$ & AcMNPVwt-AcGFP & E.aporema \\
3000 & AcGFP & E.aporema \\
\hline
\end{tabular}

Evaluación de infección mediante inyección de BV del virus AcGFP. Larvas del $3^{\text {er }}$ estadio de S. frugiperda, Epinotia aporema y A. gemmatalis fueron inyectadas con $3 \mu \mathrm{l}$ de BV del virus AcGFP (aprox. 100 p.f.u./larva). A los 6 días p.i. fueron sometidas a disección para la extracción de tejido intestinal, tejido graso, hemolinfa y tráqueas. La presencia de células infectadas se determinó mediante la elaboración de extendidos y la observación utilizando microscopia de fluorescencia.

Microscopía electrónica de barrido de membranas peritróficas. Larvas del $3^{\circ}$ estadio de Anticarsia gemmatalis fueron alimentadas con fragmentos (cubos) de dieta contaminada superficialmente con diferentes dosis (ver tabla 5.2). Las larvas control se alimentaron sin la presencia de cuerpos de oclusión viral. A las 18 hs. postratamiento, solo las larvas que ingirieron completamente la dieta fueron utilizadas para la extracción de sus membranas peritróficas. Cada larva fue inmobilizada en hielo y posteriormente diseccionada para la extracción de la MP. Las mismas se lavaron en PBS $0.1 \%$ y se fijaron a temperatura ambiente en glutaraldehído al 1\%. Cada muestra se deshidrató en una serie de etanol (50, 70, 90, y 100\%). Cada membrana se secó a temperatura ambiente y posteriormente fueron metalizadas con oro (JEOL mod. Fine Coat lon Sputter). Posteriormente se examinaron de forma individual en microscopio de barrido (JEOL, modelo JSM-6360 LV). 
Tabla 5.2. Dosis (en OBs) y virus administrados via per os a larvas de $3^{\circ}$ estadio de $A$. gemmatalis

\begin{tabular}{|c|c|c|}
\hline Dosis (OBs/larva) & Virus & Especie \\
\hline 3000 & Acgp37EpapGV & A.gemmatalis \\
3000 & AchiAEpapGV & A.gemmatalis \\
3000 & AgMNPV & A.gemmatalis \\
3000 & AcGFP & A.gemmatalis \\
\hline
\end{tabular}

Ensayos de interaccion viral entre AgMNPV y los virus recombinantes AchiAEpapgV, Acgp37EpapgV y AcGPF. Los ensayos in vivo fueron realizados según la metodología descripta por Hughes y Wood (1986). Se ensayaron diferentes dosis de virus de AgMNPV solo y en combinación con virus recombinantes de AcMNPV (Tabla 5.3).

Tabla 5.3. Dosis (en OBs) y virus administrados per os a larvas de $3^{\circ}$ estadio de $A$. gemmatalis

\begin{tabular}{|c|c|c|}
\hline Dosis (OBs/larva) & Virus & Especie \\
\hline 100 & AgMNPV & A.gemmatalis \\
$100+3000$ & AgMNPV + AchiAEpapGV & A.gemmatalis \\
$100+3000$ & AgMNPV + Agp37EpapGV & A.gemmatalis \\
$100+3000$ & AgMNPV + AcGFP & A.gemmatalis \\
\hline
\end{tabular}




\section{Resultados}

\section{Clonado de genes de EpapGV en el vector de transferencia pl2.}

El vector de transferencia pl2, permite el clonado de genes seleccionados para su expresión bajo el control del promotor de poliedrina. El vector contiene también el ORF de la poliedrina bajo el control del promotor de p10. Estas características permiten generar virus recombinantes de AgMNPV polh+ (Biedma, 2009). Los plásmidos recombinantes pl2-gp37 y pl2-chiA se obtuvieron mediante la amplificación por PCR de los respectivos ORF a partir de DNA de EpapGV. Posteriormente se clonaron el vector pGEM-T (pGEM-Tgp37 y pGEM-TchiA) que fue utilizado para confirmar la identidad de los respectivos ORF mediante secuenciación. Estos mismos plásmidos se utilizaron para obtener, mediante el uso de la enzima de restricción EcoRI los ORF completos de gp37 y chiA, cada uno con ambos extremos EcoRI. Estos fragmentos, previamente purificados, se clonaron en el vector pl2 cortado con la misma enzima (Fig. 5.2.)

Dada la disposición y orientación que poseen los genes gp37-cath y chiA en el genoma de EpapGV analizado en el capítulo anterior, fue posible utilizar los primers gp37Ep-up-EcoRI (sentido) y chiA-down-Xhol (antisentido) para la amplificación del fragmento conteniendo estos tres genes. Una vez obtenido el mismo mediante PCR (Fig. 5.3), fue purificado y digerido con las respectivas enzimas de restricción. Posteriormente fue clonado en el vector pl2 digerido con las mismas enzimas. El inserto fue confirmado mediante la técnica de PCR utilizando los pares de primers correspondientes a cada ORF individual (gp37 y chiA). 


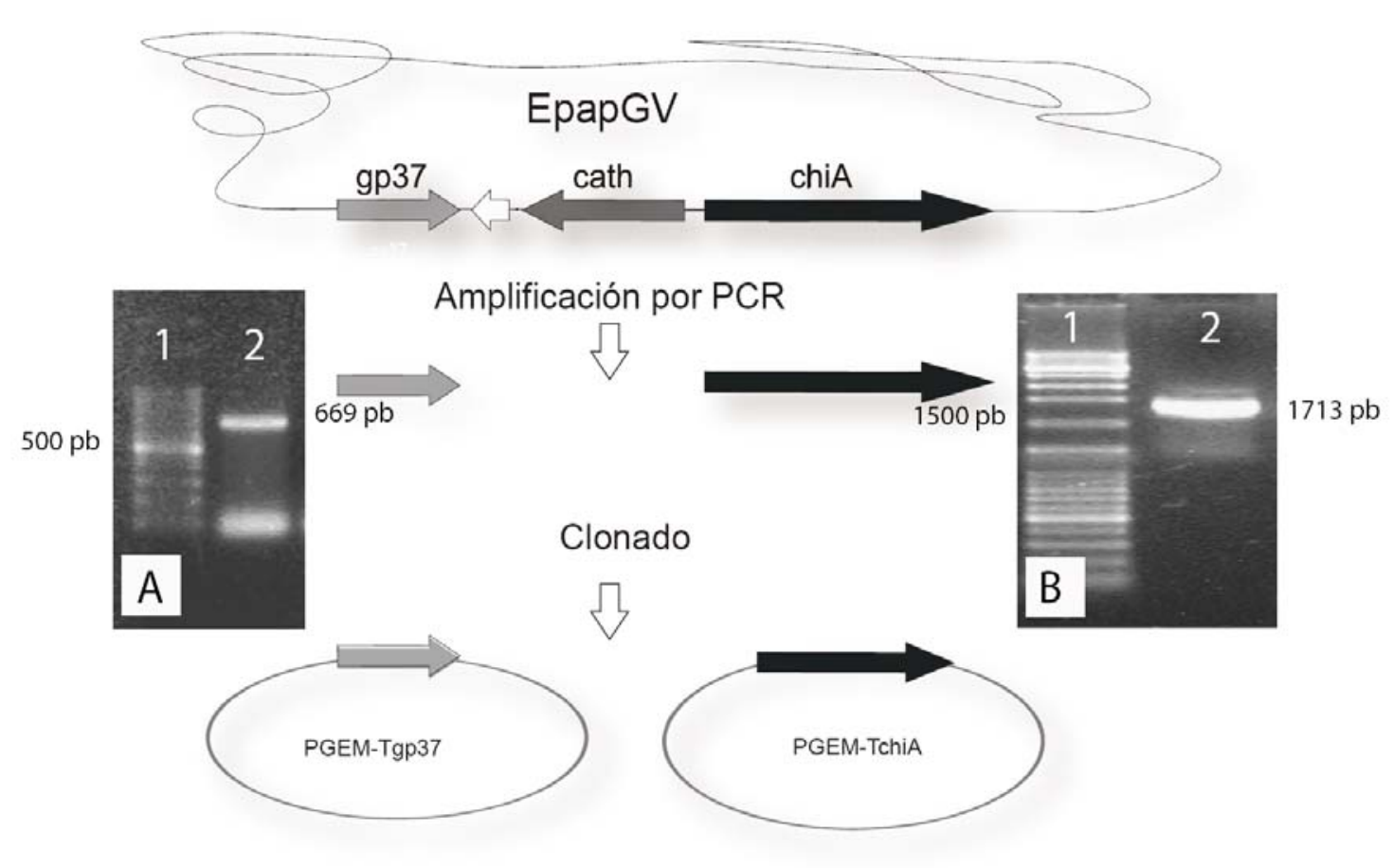

Digestión
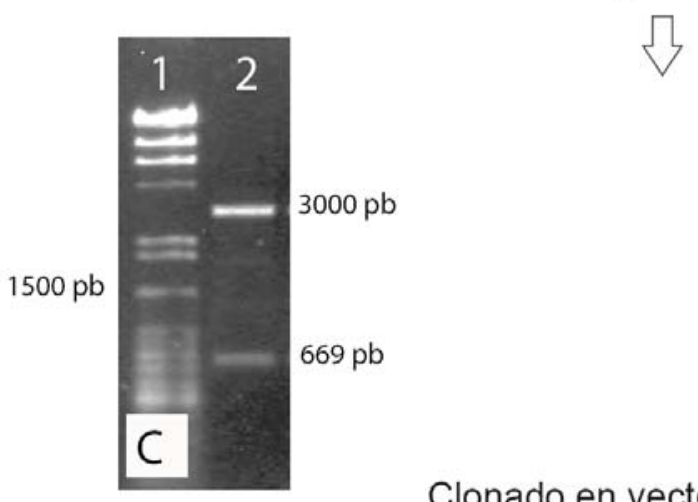

Clonado en vector de transferencia
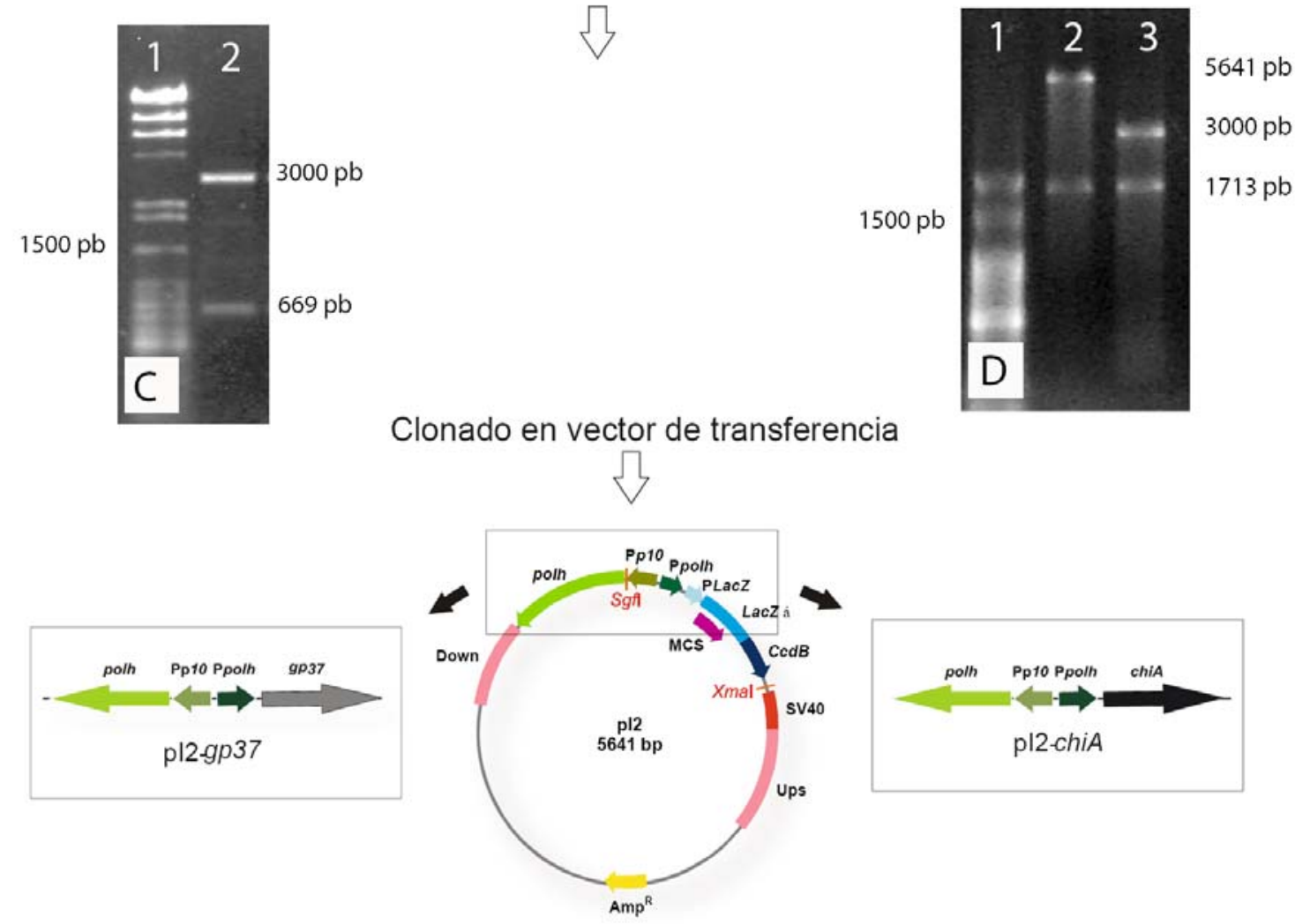

Fig. 5.2: Esquema de amplificación por PCR, clonado y confirmación mediante enzimas de restricción de los vectores de transferencia pl2-gp37 y pl2-chiA. A-B: amplificación por PCR de gp37 y chiA respectivamente. C: digestión de pGEM-Tgp37 con EcoRI. D.1-2: digestión pl2chiA y pGEM-TchiA con EcoRI respectivamente. 

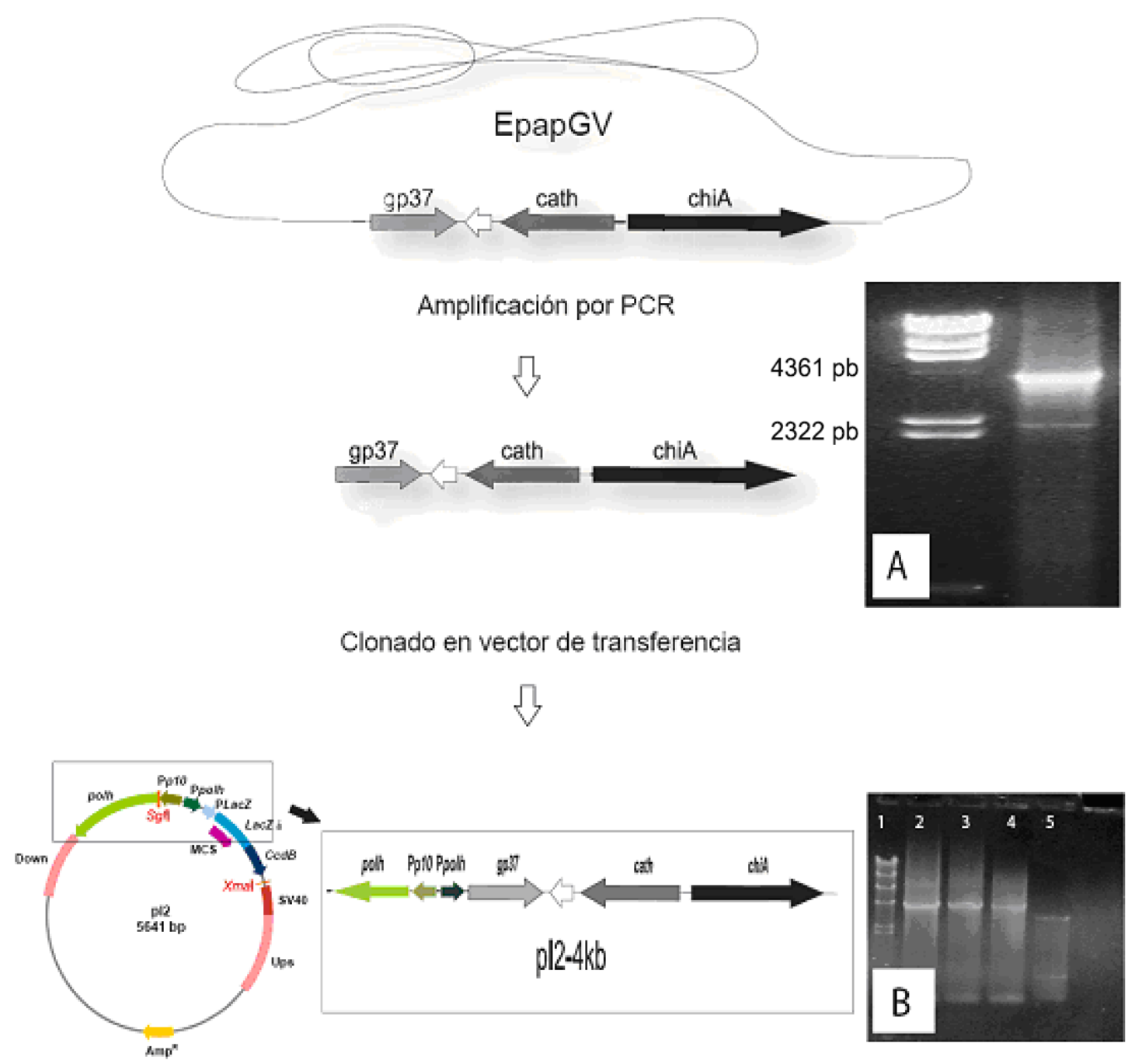

Fig. 5.3: Esquema de amplificación por PCR y clonado del fragmento de 4 kpb gp37-cath-chiA. A: amplificación por PCR del fragmento $4 \mathrm{kpb}$. En la parte inferior del grafico se observa la estructura definitiva del plasmido de transferencia con el bloque amplificado a partir del ADN de EpapGV. B: Colony PCR realizadas en clones de pl2 4kb.

\section{Generación de recombinantes de AgMNPV.}

Para obtener el virus rAgMNPV/gp37-polh+, se utilizó la estrategia clásica de intercambio alélico. Células UFLAg-286 fueron cotransfectadas con los plásmido recombinantes (pl2-gp37) y el DNA viral AgMNPV-IPpol linealizado. Para la transfección se utilizaron de forma individual tres clones diferentes del plásmido pl2gp37 (denominados I, II y 19II). El virus usado como parental en todos los experimentos de generación de recombinantes, posee el gen lacZ flanqueado por las secuencias de corte para la enzima I-Ppol, las que están rodeadas por las 
secuencias no-codificantes upstream y downstream del gen de poliedrina. Dos eventos de recombinación homóloga intercambiarán las secuencias presentes en el vector de transferencia por las del DNA viral utilizado como parental, generando así un doble recombinante.

El análisis de las células reveló que solo las transfectadas con el plásmido pl2-gp3719 II y el DNA viral linealizado presentaban poliedros. En las restantes, transfectadas con los clones pl2-gp37-I y II, si bien no se observaron poliedros, las células presentaron síntomas de infección. El virus recombinante rAgMNPV/gp37-polh+ obtenido, fue purificado mediante ensayos de placa sucesivos, reconocido por la aparición de poliedros y ausencia de coloración azul en las placas. Para confirmar la presencia de recombinantes, se utilizó DNA extraído de BV, el cual fue utilizado para la amplificación por PCR del ORF gp37 de EpapGV en el rAgMNPV (Fig. 5.4). Los resultados muestran sólo reacción positiva en el DNA proveniente de BVs obtenidos de células en las cuales fue posible observar poliedros.

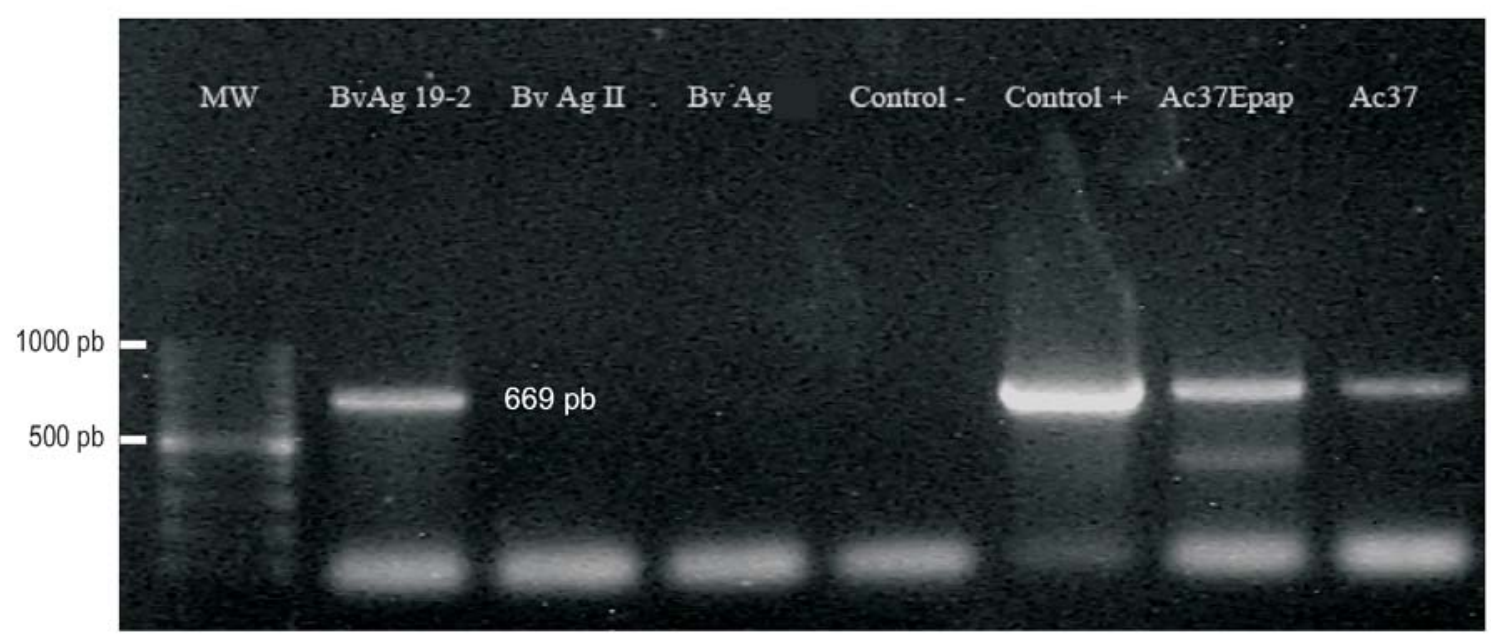

Fig. 5.4. PCR a partir de sobrenadantes de células infectadas con rAgMNPV-gp37. Calle 1: Marcador de peso molecular. Calle 2: de BVs de rAgMNPV-gp37-II19. Calle 3: de BVs de rAgMNPV-gp37II. Calle 4: de BVs de rAgMNPV-gp37. Calle 5: control negativo (AgMNPV). Calle 7: control positivo (plasmido 12-gp37). Calle 8: ADN de rAcMNPVgp37-I. . Calle 9: ADN de rAcMNPVgp37-II. 


\section{Evaluación de la expresión de genes de interés mediante Western Blot.}

Se utilizaron BVs del virus rAgMNPV /gp37-polh+ para infectar células UFLAg-286 y evaluar la expresión de GP37 mediante Western Blot. Como control positivo se utilizaron extractos proteicos de células HighFive infectadas con el virus Acgp37EpapGV y como controles negativos células infectadas con el virus salvaje AgMNPV (wt) y células sin infectar.

Los resultados muestran que no pudo detectarse la proteína GP37 en las células infectadas con el virus AgMNPV recombinante (Fig.5.5).

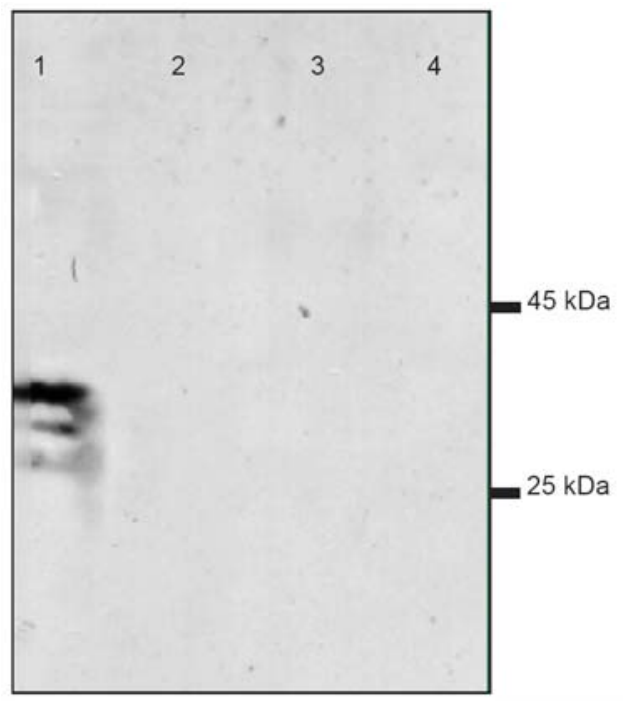

Fig. 5.5. Detección de GP37 en extractos de cultivos celulares. 1. Extracto de células HighFive infectadas con Acgp37EpapGV (control positivo). 2. Extracto de células UFLAg-286 infectadas con rAgMNPV/gp37polh+. 3. Extracto de células UFLAg-286 infectadas con AgMNPVwt. Extracto de células UFLAg-286 sin infectar.

Intentos sucesivos de expresión con éste y otros recombinantes generados con el mismo vector de expresión evidenciaron la falta de expresión proteica haciendo suponer fallas en la construcción del vector de transferencia o niveles indetectables de expresión de proteínas.

En este estudio, el vector de transferencia (pl2) fue utilizado para la inserción de los genes provenientes de EpapGV en el virus de AgMNPV. El primer gen clonado fue gp37 y luego el gen chiA de EpapGV y el bloque de $4 \mathrm{~kb}$ de tamaño que incluye a gp37, cath y chiA. Los ensayos en cultivos celulares demostraron mediante la técnica de PCR la obtención del virus recombinante de rAgMNPV/gp37-polh+ pero mediante Western blot se comprobó la ausencia de expresión de GP37. Estos resultados indican que deberá revisarse la capacidad del vector pl2 (Haase, 2010). 


\section{Evaluación de virus recombinantes de AcMNPV}

Con el objetivo de confirmar y avanzar en la evaluación de factores proteicos que pudieran estar involucrados en la alteración de la MP observada en el capítulo 2 y poner de manifiesto en forma indirecta dicha alteración, se generó un baculovirus recombiante que expresa un gen marcador (GFP-green fluorescent protein). La multiplicación de viriones brotantes postransfección en células HighFive permitió comprobar la presencia del recombinante no sólo por la aparcición de poliedros en el cultivo celular sino también por la visualización de fluorescencia (Fig. 5.6).

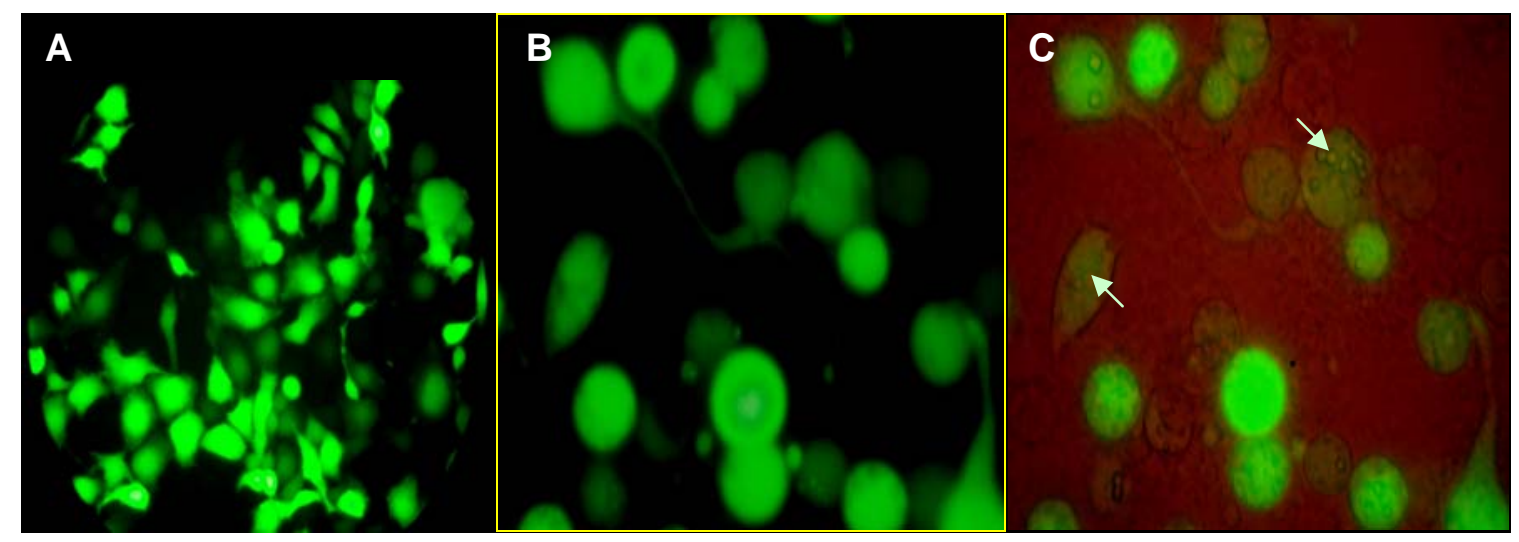

Fig. 5.6: Células High Five infectadas con AcGFP observadas bajo microscopio de epifluorescencia (A: 400X; B y C: 1000X). Con flechas se indica la presencia de poliedros.

La obtención del virus AcMNPV-GFP-polh+ aporta una herramienta que posibilita determinar cualitativamente el desarrollo de la infección en el hospedador. Este virus resulta infectivo por vía oral y ofrece la posibilidad de evaluar en diferentes tejidos la evolución temporal del proceso infectivo. Trabajos previos indican que un daño sobre la membrana peritrófica en etapas iniciales de la infección se traduce en una rápida diseminación sistémica del virus y descensos en los parámetros biológicos de $\mathrm{TL}_{50}$ y $\mathrm{DL}_{50}$ (Derksen \& Granados, 1988a; Lara-Reyna et al., 2003; Lepore et al., 1996; Mitsuhashi et al., 1998; Mitsuhashi et al., 2007; Mitsuhashi \& Miyamoto, 2003; Mitsuhashi \& Sato, 2000; Peng et al., 1999; Takemoto et al., 2008; Tanada et al., 1973). Por lo expuesto, la realización de ensayos con larvas coinfectadas per os con mezclas de este virus marcado y los recombinantes de AcMNPV conteniendo genes de EpapGV obtenidos previamente, nos permitiría 
determinar de forma indirecta el posible daño que los recombinantes podrían ocasionar.

En una primera instancia, se evaluó la capacidad infectiva de OBs y BVs de AcGFP en larvas de Anticarsia gemmatalis, Spodoptera frugiperda y Epinotia aporema (Fig 5.7). Al momento de la realización de los ensayos no existían antecedentes sobre la patogénesis de AcMNPV sobre $A$. gemmatalis y $E$. aporema. En relación a $S$. frugiperda, todos los estudios fueron realizados sobre los últimos estadios larvales (Clarke \& Clem, 2002; Haas-Stapleton et al., 2003; 2005), no habiendo referencias respecto a lo que sucede cuando AcMNPV es administrado en las primeras etapas del desarrollo larval. Por tal motivo se decidió evaluar el efecto de AcGFP sobre el $3^{\text {er }}$ estadio de las larvas mencionadas anteriormente, utilizando dosis calculadas en base a la dosis letal media reportada para larvas de $5^{\text {to }}$ estadio de $S$. frugiperda (DL50 9200 OBs/larva) (Hass-Stapleton et al., 2005) (Ver Tabla 5.1).

Los resultados del ensayo realizado con el virus AcGFP administrado vía per os e intrahemocélica en larvas de $A$. gemmatalis, E. aporema y $S$ frugiperda indicaron que solo se detecta infección con la administración de BV por inyección en larvas de S. frugiperda y más tardíamente en $A$. gemmatalis (Fig.5.7); mientras no se observaron células infectadas en los insectos tratados, cuando se sumistraron OBs vía oral. Ningún síntoma de infección fue observado en larvas de $E$. aporema sometidas a los mismos tratamientos (datos no mostrados).

Estudios recientes indican que el virus de AcMNPV infecta larvas del $5^{\circ}$ estadio de $A$. gemmatalis vía per os, solo a muy elevadas dosis ( $\left.\mathrm{DL}_{50}>5.5 \times 10^{5} \mathrm{OB} / \mathrm{larva}\right)$ y solo unos pocos tipos celulares parecen permitir la replicación viral cuando este virus es administrado vía per os o intrahemócelica a dosis también elevadas (Chikhalya et al., 2009).

La falta de infección vía per os en larvas de $A$. gemmatalis y $S$. frugiperda determinada en este trabajo podría ser debida a la utilización de dosis insuficientes como para causar la infección, aunque probablemente este inconveniente podría estar relacionado con la interaccion entre el ODV y receptores presentes en las células del intestino del hospedador (Haas-Stapleton et al., 2005). En cambio, el uso de BVs inyectados vía intrahemocélica mostraron resultados coincidentes con lo 
descrito por otros autores (Clarke \& Clem, 2002; Chikhalya et al., 2009; HaasStapleton et al., 2003; 2005).
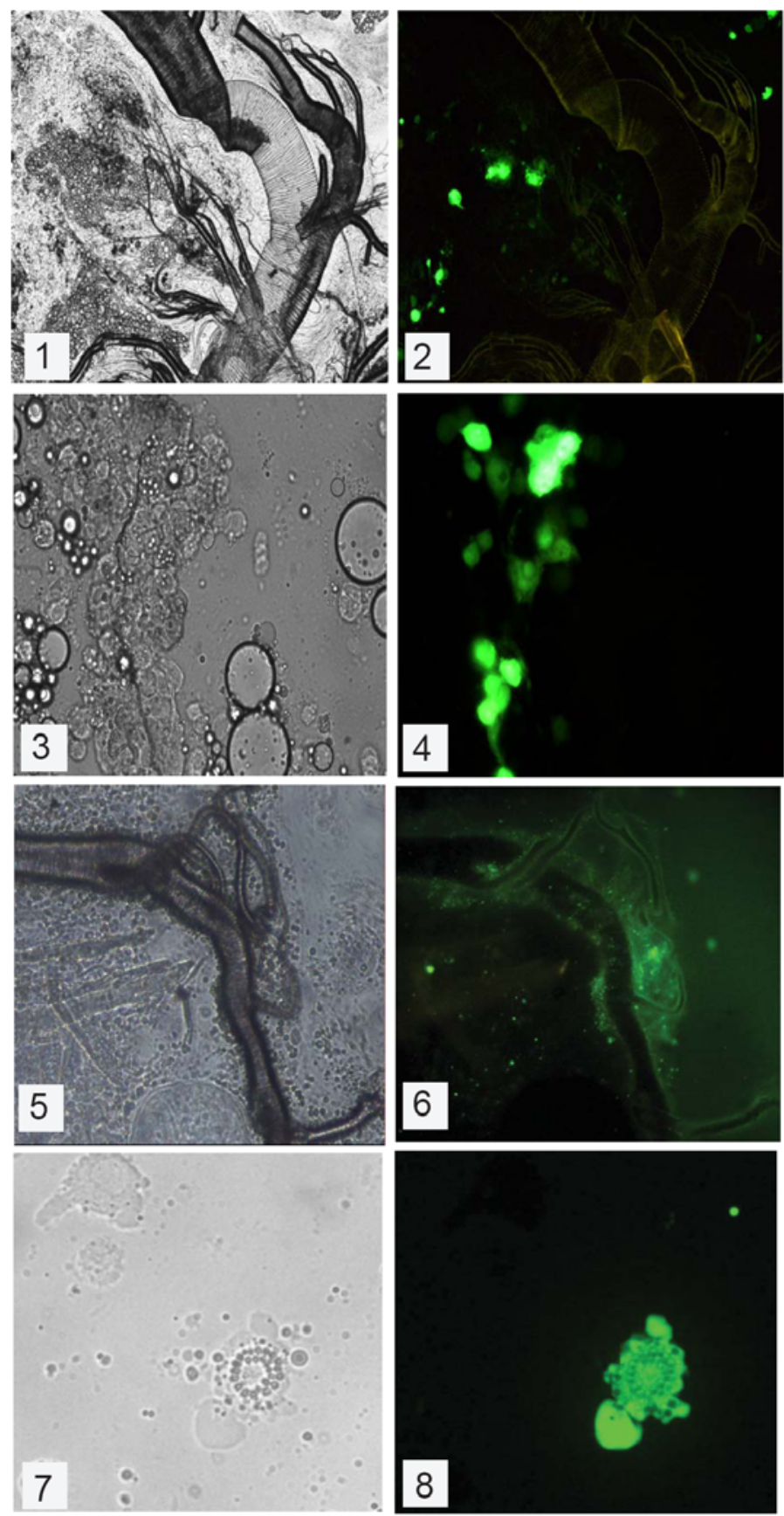

Fig. 5.7. Evaluación del virus AcGFP en larvas de A. gemmatalis y $S$. frugiperda mediante inyección intrahemocélica. En todas las fotos la columna de la izquierda representa la observación con luz blanca y la columna de la derecha con luz UV. 1-2. Tráqueas y tejido adiposo de A. gemmatalis (Aumento 1000x). 3-4. Tejido adiposo de A. gemmatalis (Aumento400x). 5-6. Tráqueas de S. frugiperda (Aumento 400x). 7-8. Hemolinfa de S. frugiperda, en el interior de las células infectadas es posible observar la presencia de poliedros (Aumento 400x). 


\section{Evaluación de Acgp37EpapGV y AcchiAEpapGV en combinación con AgMNPV}

Considerando lo expuesto anteriormente, se propuso evaluar si el agregado de los rAcMNPVs que expresan genes de EpapGV presentaba algún efecto sobre la mortalidad producida por AgMNPV en su hospedante natural y, de manera indirecta, su acción sobre la MP.

Se evaluaron entonces mezclas de OBs de los recombinantes Acgp37EpapGV, AcchiAEpapGV y de OBs de AgMNPV, en larvas de $3^{\text {er }}$ estadio y en una dosis inferior a la $\mathrm{DL}_{50}$ calculada para este estadio (168 OBs/larva).

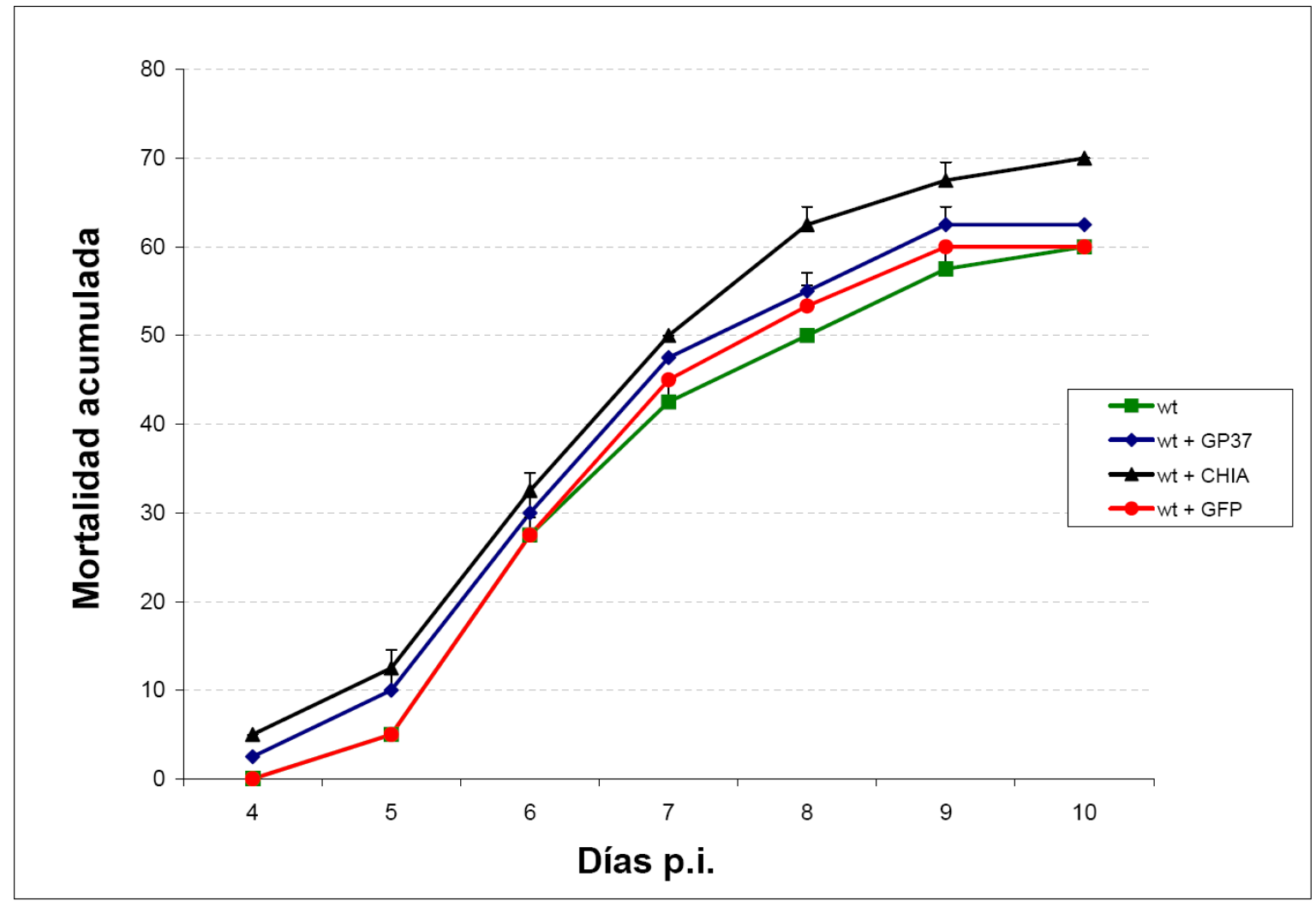

Fig. 5.8. Efecto de la administración de mezclas virales compuestas por OB de AgMNPV (wt) y de virus recombinantes de AcMNPV (GP37, CHIA y GFP respectivamente) sobre larvas del 3er estado de $A$. gemmatalis

Los resultados indican que la adición de OBs de recombinantes del virus de AcMNPV a OBs de AgMNPV genera un aumento de la mortalidad en larvas de $3^{\text {er }}$ estadio de $A$. gemmatalis. El efecto más notorio se observa con el agregado de OBs del recombinante de AchiAEpapGV, aumentando en un 10\% la mortalidad de las larvas en relación a la mortalidad ocasionada por el virus de AgMNPV salvaje. El 
agregado de OBs de Acgp37EpapGV y AcGFP producen un leve incremento de la mortalidad en relación al virus salvaje pero que no es tan notorio como el ocasionado por el virus que sobreexpresa CHIA.

En relación con los resultados mostrados anteriormente y considerando que estos recombinantes a las dosis evaluadas no son capaces de generar una infección por administración oral de OBs, se puede sugerir que el aumento en la mortalidad es debida a factores que están asociados a los OBs de los recombinantes.

En el capítulo anterior de esta tesis se evidenció la presencia de CHIA en los OBs y que esta enzima es capaz de retener su actividad en medios alcalinos. Por tal motivo se realizaron experimentos complementarios para determinar si el incremento en la mortalidad observado en los bioensayos con mezclas de OBs del virus de AgMNPV salvaje y los recombinantes, había sido producido por factores asociados a los OBs de estos últimos

Los mismos tratamientos usados en los bioensayos descriptos anteriormente (Tabla 5.3), fueron administrados a larvas del $3^{\text {er }}$ estadio de $A$. gemmatalis a las cuales posteriormente se les extrajo la membrana peritrófica para su evaluación mediante microscopia electrónica de barrido (MEB). Lo observado indica que solo en las MP extraídas de larvas tratadas con mezclas conteniendo OB de AchiAEpapGV pudo visualizarse alteraciones en la estructura, en comparación con MP de larvas tratadas con las otras mezclas virales. Estas alteraciones consisten en regiones con estructura irregular en las cuales se evidencian perforaciones o poros que interrumpen la continuidad de la membrana (Fig.5.7).

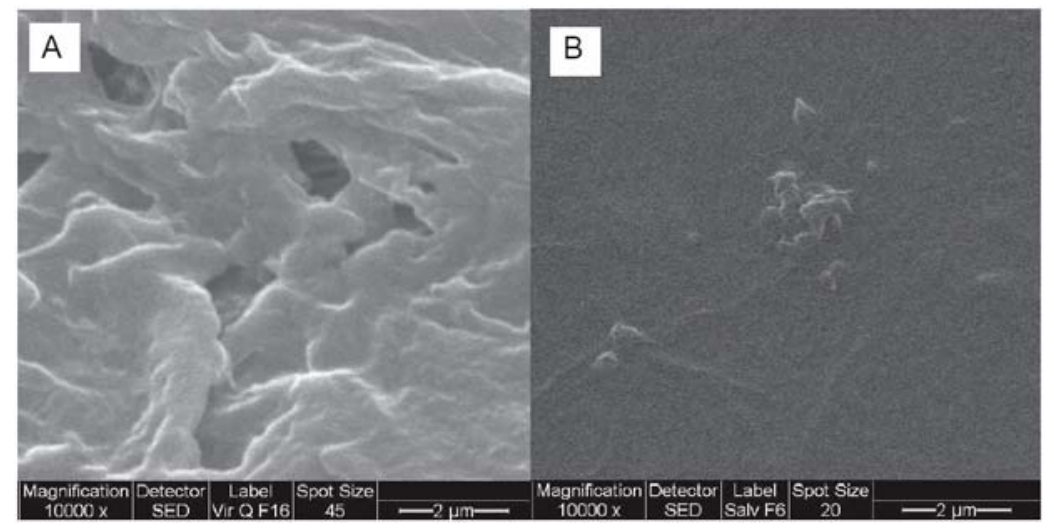

Fig. 5.7. MEB de membranas extraídas de larvas tratadas con virus AchiAEpapGV (A) y con virus AcGFP (B) 
Antecedentes previos describen la presencia de CHIA en poliedros (Hawtin et al., 1997). Además, estudios realizados in vitro sobre MP con CHIA de AcMNPV expresada y purificada de bacterias, indicaron que el daño ejercido sobre la membrana es proporcional a la concentración de la CHIA administrada. Una elevada concentración de CHIA administrada in vivo junto con OBs, no solo deteriora la MP sino también genera un aumento en la mortalidad larval (Rao et al., 2004). Pero ningún estudio había evaluado tales aseveraciones in vivo, siendo este es el primer trabajo que analiza in vivo (en larvas de insecto) los efectos sobre la MP, de poliedros provenientes de virus modificados genéticamente

En las membranas sometidas a las mezclas virales conteniendo AgMNPV y Acgp37EpapGV y posteriormente analizadas mediante microscopia electrónica no se observaron los cuerpos proteicos descriptos en el capitulo 2, por lo tanto se concluye que los mismos son codificados por el genoma de EpapGV y su naturaleza proteica aún debe ser determinada. 


\section{Referencias}

Bora Inceoglu, S. G. K., and Bruce D. Hammock (2006). Genetically modified baculoviruses : A historical overview and future Outlook. In: Advances in Virus Reserarch.

Biedma, M. E. (2009). "Desarrollo de un sistema de recombinación para su aplicación al estudio de determinantes genéticos que afectan la infectividad debaculovirus de interés agronómico". Tesis Doctoral, Facultad de Ciencias Exactas, UNLP La Plata.

Birnbaum, M. J., Clem, R. J. \& Miller, L. K. (1994). An apoptosis-inhibiting gene from a nuclear polyhedrosis virus encoding a polypeptide with Cys/His sequence motifs. $J$ Virol 68, 2521-2528.

Bischoff, D. S. \& Slavicek, J. M. (1997). Molecular analysis of an enhancin gene in the Lymantria dispar nuclear polyhedrosis virus. J Virol 71, 8133-8140.

Black, B. C., Brennan, L. A., Dierks, P. M., and Gard, I. E. (1997). Commercialization of baculoviral insecticides. In "The Baculoviruses" (L. K. Miller, ed.), pp. 341-387. Plenum Press, New York.

Burden, J. P., Hails, R. S., Windass, J. D., Suner, M. M. \& Cory, J. S. (2000). Infectivity, speed of kill, and productivity of a baculovirus expressing the itch mite toxin txp-1 in second and fourth instar larvae of Trichoplusia ni. J Invertebr Pathol 75, 226-236.

Carbonell, L. F., Hodge, M. R., Tomalski, M. D. \& Miller, L. K. (1988). Synthesis of a gene coding for an insect-specific scorpion neurotoxin and attempts to express it using baculovirus vectors. Gene 73, 409-418.

Clarke, T. E. \& Clem, R. J. (2002). Lack of involvement of haemocytes in the establishment and spread of infection in Spodoptera frugiperda larvae infected with the baculovirus Autographa californica M nucleopolyhedrovirus by intrahaemocoelic injection. J Gen Virol 83, 1565-1572.

Cory, J. S. \& Bishop, D. H. (1995). Use of baculoviruses as biological insecticides. Methods Mol Biol 39, 277-294.

Cory, J. S., Hirst, M. L.,Williams, T., Halls, R. S., Goulson, D., Green, B. M., Carty, T. M., Possee, R. D., Cayley, P. J., and Bishop, D. H. L. (1994). Field trial of a genetically improved baculovirus insecticide. Nature (London) 370:138-140.

.Chikhalya, A., Luu, D. D., Carrera, M., De La Cruz, A., Torres, M., Martinez, E. N., Chen, T., 
Stephens, K. D. \& Haas-Stapleton, E. J. (2009). Pathogenesis of Autographa californica multiple nucleopolyhedrovirus in fifth-instar Anticarsia gemmatalis larvae. J Gen Virol 90, 2023-2032.

Derksen, A. C. \& Granados, R. R. (1988a). Alteration of a lepidopteran peritrophic membrane by baculoviruses and enhancement of viral infectivity. Virology 167, 242250.

Derksen, A. C. \& Granados, R. R. (1988b). Alteration of a lepidopteran peritrophic membrane by baculoviruses and enhancement of viral infectivity. Virology 167, 242250.

Greene, G. L., Leppla, N. C. \& Dickerson, W. A. (1976). Velvetbean caterpillar: a rearing procedure and artificial medium. J Econ Entomol 69, 487-488.

Gross, C. H., Wolgamot, G. M., Russell, R. L., Pearson, M. N. \& Rohrmann, G. F. (1993). A 37-kilodalton glycoprotein from a baculovirus of Orgyia pseudotsugata is localized to cytoplasmic inclusion bodies. J Virol 67, 469-475.

Haas-Stapleton, E. J., Washburn, J. O. \& Volkman, L. E. (2003). Pathogenesis of Autographa californica M nucleopolyhedrovirus in fifth instar Spodoptera frugiperda. J Gen Virol 84, 2033-2040.

Haas-Stapleton, E. J., Washburn, J. O. \& Volkman, L. E. (2005). Spodoptera frugiperda resistance to oral infection by Autographa californica multiple nucleopolyhedrovirus linked to aberrant occlusion-derived virus binding in the midgut. J Gen Virol 86, 1349-1355.

Hawtin, R. E., Zarkowska, T., Arnold, K., Thomas, C. J., Gooday, G. W., King, L. A., Kuzio, J. A. \& Possee, R. D. (1997). Liquefaction of Autographa californica nucleopolyhedrovirus-infected insects is dependent on the integrity of virus-encoded chitinase and cathepsin genes. Virology 238, 243-253.

Hughes, P. R. W., H., A. (1986). In vivo and In vitro Bioassay Methods for Baculoviruses. In The Biology of Baculoviruses, Biological Properties and Molecular Biology. Edited by R R G a B A Federeci Boca Raton, Florida: CRC Press

Katou, Y., Ikeda, M. \& Kobayashi, M. (2006). Abortive replication of Bombyx mori nucleopolyhedrovirus in Sf9 and High Five cells: defective nuclear transport of the virions. Virology 347, 455-465.

Laemmli, U. K. (1970). Cleavage of structural proteins during the assembly of the head of bacteriophage T4. Nature 227, 680-685. 
Lara-Reyna, J., Del Rincon-Castro, M. C. \& Ibarra, J. E. (2003). Synergism between the nucleopolyhedroviruses of Autographa californica and Trichoplusia ni. Acta Virol 47, 189-194.

Lepore, L. S., Roelvink, P. R. \& Granados, R. R. (1996). Enhancin, the granulosis virus protein that facilitates nucleopolyhedrovirus (NPV) infections, is a metalloprotease. $J$ Invertebr Pathol 68, 131-140.

Levidow, L. (1995). The Oxford baculovirus controversy: Safely testing safety? Biosci. 45(8):545-551.

.Li, Z., Li, C., Yang, K., Wang, L., Yin, C., Gong, Y. \& Pang, Y. (2003). Characterization of a chitin-binding protein GP37 of Spodoptera litura multicapsid nucleopolyhedrovirus. Virus Res 96, 113-122.

Lopez-Ferber.(2001). Baculovirus recombinantes en el control Integrado. En Los baculovirus y sus aplicaciones en el control biológico de plagas. Caballero P., Williams T. y Lopez-Ferber M.

Martens, J. W., Honee, G., Zuidema, D., van Lent, J. W., Visser, B. \& Vlak, J. M. (1990). Insecticidal Activity of a Bacterial Crystal Protein Expressed by a Recombinant Baculovirus in Insect Cells. Appl Environ Microbiol 56, 2764-2770.

McCarthy, C. B. (2005). Generación de recombinantes del virus de la poliedrosis nuclear de Anticarsia gemmatalis (AgMNPV). Tesis Doctoral, Facultad de Ciencias Exactas, $p$ 339 La Plata: Universidad Nacional de La Plata.

McCarthy, C. B. \& Theilmann, D. A. (2008). AcMNPV ac143 (odv-e18) is essential for mediating budded virus production and is the 30th baculovirus core gene. Virology $375,277-291$.

Mitsuhashi, W., Furuta, Y. \& Sato, M. (1998). The spindles of an entomopoxvirus of coleoptera (Anomala cuprea) strongly enhance the infectivity of a nucleopolyhedrovirus in lepidoptera. J Invertebr Pathol 71, 186-188.

Mitsuhashi, W., Kawakita, H., Murakami, R., Takemoto, Y., Saiki, T., Miyamoto, K. \& Wada, S. (2007). Spindles of an entomopoxvirus facilitate its infection of the host insect by disrupting the peritrophic membrane. J Virol 81, 4235-4243.

Mitsuhashi, W. \& Miyamoto, K. (2003). Disintegration of the peritrophic membrane of silkworm larvae due to spindles of an entomopoxvirus. J Invertebr Pathol 82, 34-40.

Mitsuhashi, W. \& Sato, M. (2000). Enhanced Infection of a Nucleopolyhedrovirus in a 
Lepidopteran Pest (Spilosoma imparilis) by Spindles of a Coleopteran Entomopoxvirus (EPV) (Anomala cuprea EPV). Japanese Forestry Society 5, 3.

O'Reilly, D. R., Miller, L. K. \& Luckow, V. A. (1992). Baculovirus Expression Vectors: A Laboratory Manual. New York: WH Freeman and Company.

Oliveira, J. V., Wolff, J. L., Garcia-Maruniak, A., Ribeiro, B. M., de Castro, M. E., de Souza, M. L., Moscardi, F., Maruniak, J. E. \& Zanotto, P. M. (2006). Genome of the most widely used viral biopesticide: Anticarsia gemmatalis multiple nucleopolyhedrovirus. J Gen Virol 87, 3233-3250.

Peng, J., Zhong, J. \& R, R. G. (1999). A baculovirus enhancin alters the permeability of a mucosal midgut peritrophic matrix from lepidopteran larvae. J Insect Physiol 45, 159166.

Rao, R., Fiandra, L., Giordana, B., de Eguileor, M., Congiu, T., Burlini, N., Arciello, S., Corrado, G. \& Pennacchio, F. (2004). AcMNPV ChiA protein disrupts the peritrophic membrane and alters midgut physiology of Bombyx mori larvae. Insect Biochem $\mathrm{Mol}$ Biol 34, 1205-1213.

Richards, A., Matthews, M. \& Christian, P. (1998). Ecological considerations for the environmental impact evaluation of recombinant baculovirus insecticides. Annu Rev Entomol 43, 493-517.

Rincón-Castro, D. (1997). Tesis. Guanajuato. Irapuato. Mexico.

Sieburth, P. J. (1988). Growth characteristics of a continuous cell line from the velvetbean caterpillar, Anticarsia gemmatalis Hübner (Lepidoptera: Noctuidae). In Vitro Cellular \& Developmental Biology 24, 195-198.

Stewart, L. M., Hirst, M., Lopez Ferber, M., Merryweather, A. T., Cayley, P. J. \& Possee, R. D. (1991). Construction of an improved baculovirus insecticide containing an insectspecific toxin gene. Nature $352,85-88$.

Takemoto, Y., Mitsuhashi, W., Murakami, R., Konishi, H. \& Miyamoto, K. (2008). The Nterminal region of an entomopoxvirus fusolin is essential for the enhancement of peroral infection, whereas the C-terminal region is eliminated in digestive juice. $J$ Virol 82, 12406-12415.

Tanada, Y., Himeno, M. \& Omi, E. M. (1973). Isolation of a factor, from the capsule of a granulosis virus, synergistic for a nuclear-polyhedrosis virus of the armyworm. $J$ Invertebr Pathol 21, 31-40. 
Tomalski, M. D. \& Miller, L. K. (1991). Insect paralysis by baculovirus-mediated expression of a mite neurotoxin gene. Nature $352,82-85$.

Ure, A. (2009). Tesis Doctoral: "Desarrollo de proteínas recombinantes para el diagnóstico y prevención de la fiebre hemorrágica argentina“. Fac. Cs. Exactas. UNLP.

Vialard, J. E., Yuen, L. \& Richardson, C. D. (1990). Identification and characterization of a baculovirus occlusion body glycoprotein which resembles spheroidin, an entomopoxvirus protein. J Virol 64, 5804-5811.

Wang, P. \& Granados, R. R. (1997). An intestinal mucin is the target substrate for a baculovirus enhancin. Proc Natl Acad Sci U S A 94, 6977-6982.

Wood, H. A., Hughes, P. R., and Shelton, A. (1994). Field studies of the coocclusion strategy with a genetically altered isolate of the Autographa californica nuclear polyhedrosis virus. Environ. Entomol. 23(2):211-219. 


\title{
Conclusiones Generales
}

\author{
y Perspectivas
}




\section{Conclusiones}

- En ensayos de inoculación conjunta de EpapgV y AgMNPV en larvas de $A$. gemmatalis se observó un incremento de la virulencia de AgMNPV cuando se administraba en forma simultánea con EpapGV. Los efectos resultaron más notorios a dosis bajas de AgMNPV.

- Luego de la aplicación de la mezcla viral se observaron alteraciones sobre la membrana peritrófica del hospedador y variaciones en el perfil proteico obtenido de dichas membranas.

- La búsqueda de genes del tipo vef en el genoma de EpapGV no dió resultados positivos; estos fueron coherentes con el análisis de la secuencia completa que se obtuvo recientemente, el cual confirmó la ausencia de este gen

- Se determinaron las secuencias nucleotídicas completas de los genes gp37, chiA y cath. Se dedujeron las secuencias aminoacídicas de sus productos y se definieron motivos característicos.

- Los ORFs de gp37 y chiA fueron clonados y expresados en células de insecto usando baculovirus recombinantes. Las proteínas obtenidas de ambos genes permitieron realizar estudios de caracterización estructural y funcional de los mismos.

- Este trabajo constituye el primer análisis de GP37 en granulovirus. La reactividad cruzada de esta proteína con anticuerpos específicos contra las fusolinas de entomopoxvirus confirmaron la similitud aminoacídica descripta entre éstas y las GP37 baculovirales. 
- Los recombinantes obtenidos con los genes de gp37 y chiA de EpapGV permitieron evaluar el efecto de la sobre-expresión proteica de los mismos cuando son administrados vía oral.

- La obtención de un virus recombinante AcMNPV con un gen marcador (GFP) permitió analizar indirectamente el efecto de la alteración de la membrana peritrófica de larvas de AgMNPV, producida por la acción de la quitinasa de EpapGV.

- La presencia de inclusiones proteicas detectadas mediante microscopía electrónica hace suponer la cristalización de GP37 de EpapGV. La ausencia de reactividad con anticuerpos específicos puede haberse debido a la escasa cantidad de cristales presentes en preparados de OBs obtenidos de larvas infectadas con este virus.

- El uso de las secuencias disponibles de estos genes permitió la realización de un análisis filogenético, que en base a los resultados obtenidos hace posible plantear nuevos eventos de transferencia genética entre los baculovirus, los entomopoxvirus y las bacterias. 


\section{Perspectivas}

Los ensayos in vivo utilizando mezclas virales permiten evaluar el tipo de interacciones existentes entre sus componentes y determinar la viabilidad de formulaciones que contengan más de un agente de biocontrol. Actualmente se conocen numerosos baculovirus de hospedadores que coexisten en un mismo nicho ecológico generando perjuicios a los cultivos. El hallazgo de interacciones que optimicen la actividad insecticida como la demostrada en este estudio entre EpapGV cuando es aplicado en forma conjunta con AgMNPV sobre $A$. gemmatalis permite el diseño de estrategias de aplicación conjunta que por un lado amplía el número de plagas a controlar con una misma aplicación, y por el otro incrementa su efectividad como agente de control.

Otra alternativa para optimizar la acción de los baculovirus en el control de especies plaga se basa en su modificación genética. En este sentido, se obtuvieron AcMNPVs recombinantes que expresan los genes gp37 y chiA de EpapGV, sobreexpresados bajo el promotor de poliedrina, que podrán ser empleados en ensayos sobre especies permisivas a la infección por AcMNPV (como por ejemplo Rachiplusia nu, plaga polífaga y clave en el cultivo de girasol), con el fin de evaluar su potencial de utilización.

En forma indirecta se logró evaluar el efecto de la quitinasa de EpapGV en el incremento de la virulencia de AgMNPV y sobre membranas peritróficas de las larvas tratadas. Tales efectos no han podido ser verificados aún con el AcMNPV que expresa GP37 de EpapGV. Cabe considerar que ambas proteínas, así como 
CATH, podrían interactuar en ese proceso. Por lo tanto, será necesario evaluar su efecto en inoculaciones conjuntas y generar nuevos recombinantes que expresen estos genes en combinaciones y el bloque de los genes gp37, chiA y cath. Estas actividades se verán facilitadas sobre la base de las herramientas generadas en este trabajo.

Por otra parte, no pudo asociarse los cuerpos presentes en mezclas de OBs de EpapGV con la proteína GP37. En este sentido será necesario obtener anticuerpos específicos que permitan completar los estudios de localización subcelular y/o su posible asociación con el cuerpo oclusión viral.

Recientemente se ha obtenido un nuevo vector para permitir la expresión de genes de interés en el genoma de AgMNPV. Los genes clonados y caracterizados en esta tesis, podrán ser utilizados en la generación de nuevos recombinantes AgMNPV con eficiencia mejorada genéticamente. 
